\author{
Dr. sc. Dijana Jakovac-Lozić \\ redovita profesorica u trajnom zvanju Pravnog fakulteta u Splitu
}

\title{
NASTOJANJA NA PUTU "RANE SEKSUALIZACIJE" DJECE - INTERES DJETETA ILI POTREBA ODRASLIH
}

UDK: 342.7-053.2

DOI: $10.31141 /$ ZRPFS.2020.57.136.479

Izvorni znanstveni rad

Primljeno: 1. listopada 2019.

Jedan od značajnijih mehanizama na putu stvaranja nekog novog društvenog poretka jest indoktrinacija djece. U eri prevalencije hegemonističko-globalističkih ideja i stremljenja koja svijet budućnosti percipiraju kao masu bez povijesti, kulture i identiteta, u vremenu gašenja ili barem erodiranja dječjih prava, radničkih prava, prava nerođenih, starijih, bolesnih, bujaju seksualna prava i to ona namijenjena najmlađima. Rad na postizanju otuđenja od stvarnosti stremi najgnusnijemu - seksualizaciji djece. Većim dijelom biva kanaliziran kroz obvezne odgojno-obrazovne modele (od vrtića do škola). K tome, ne smijemo smetnuti s uma ni ulogu kontinuiteta 'širenja prostora slobode', zahvaljujući utjecajima suvremenih tehnologija (internet, društvene mreže i sl.), čime se dodatno šire prostori mogućnosti manipulacije, kao i kontrole utjecaja na djecu.

Iza ovoga stoje nagnuća svjetskih centara moći, međunarodnih organizacija, počevši od Ujedinjenih naroda, preko Vijeća Europe do Europske unije. Isti daju izniman "doprinos" na području navedenog segmenta suvremene puerikulture. Istodobno roditeljska uloga nikada nije bila na većoj kušnji i nikada nije bila do te mjere marginalizirana kao sada. Međunarodna zajednica, postavljajući se u ulogu fanatičnog "popravljača svijeta", roditeljima otima vlastito potomstvo, obrazujući ih i odgajajući prema zacrtanim postulatima. Međutim, osim odgojno-obrazovnih programa, djeca se izravno uvode u domenu rane seksualizacije i kroz suživot u 'nenaravnom' roditeljskom (istospolnom, transrodnom) okruženju, što je dio i hrvatskog pravnog realiteta. Pitamo se gdje se u svem tom metežu gomilanja i mrvljenja ljudskih prava, značaja političke i ine korektnosti, pogubila dobrobit djeteta kao imperativ te najbolji interes djeteta kao pravo nad svakim pravom? Pogubili su se upravo u trenutku u kojem nam je živjeti - trenutku slobode ludosti i stida zdravoumnosti.

Ključne riječi: prava djeteta, rana seksualizacija djece, Ujedinjeni narodi, Vijeće Europe, Europska unija, zdravstveni i spolni odgoj djece

"Children aren't coloring books. You don't get to fill them with your favorite colors."

Khaled Hosseini, The Kite Runner, New York, 2003., p. 21. 


\section{UVOD}

Sukladno citatu s početka rada, djecu je doista nemoguće nužno oblikovati na način kako to priželjkuju roditelji. Ona se pojavljuju s vlastitom osobnošću neovisno o željama roditelja, naprosto, nemoguće ih je bojati roditeljima omiljenim bojama. K tome, u odgoju djece, osim roditelja, svoje tragove ostavlja i okruženje: škola, učitelji, prijatelji, mediji... Međutim, uloga roditelja kao prvog i najvažnijeg odgojitelja, nezamjenjiva je, rekli bismo, ona je kruh i voda, srce i duša njegova odrastanja. Kako bi kazao Jasper Juul, ${ }^{1}$ “... djeca imaju 200 posto povjerenja u svoje roditelje. Za njih je ljubav način na koji ih roditelji vole. Većina nas odrasla je u vrijeme kada je osjećaj ljubavi bio dovoljan. Danas moramo priznati da osjećaj ljubavi nije dovoljan. Osjećaj ljubavi trebamo pretvoriti u ponašanje puno ljubavi”. ${ }^{2}$ Roditeljstvo koje uključuje puninu ljubavi uloga je koja posljedično podrazumijeva kontinuitet budnosti, rada na sebi, retrospekcije, samoevaluacije, usudili bismo se kazati, ono je najodgovornije životno poslanje namijenjeno čovjeku.

Život svjedoči da odgajanje može biti i rana i lijek, i tuga i smijeh, može biti uzrastanje i propadanje, može rađati očovječenjem i raščovječenjem, a sve u dobroj namjeri, prema nekim našim, roditeljskim (čitaj: ljudskim) odabirima spektra vrijednosti, osjećaja za dobro, pače za najbolje, jer je riječ o našem djetetu. Kada sličici već formiranih, raspoloživih roditeljskih kapaciteta pridodamo, prioritetno uz radosti, ujedno i dvojbe, strahove, očekivanja kojima obiluje roditeljstvo i s kojima je isto neminovno povezano u svim etapama djetetova odrastanja, pa i, između ostaloga, primjerice, s etapom zbunjenosti glede prihvaćanja vlastitog spola i nesposobnosti da se $\mathrm{s}$ njime poistovjeti - za koju imamo već i domišljeno prikladno nazivlje "rodna zbunjenost", "rodna konfuzija" ili "rodna inkongruencija" - onda postaje jasno koliko roditeljima može biti teško živjeti u svijetu u kojem se prenaglašava (i to ne slučajno) važnost i značaj ovog, u pravilu, prolaznog razdoblja ljudskog odrastanja i sazrijevanja.

Stvarnost roditeljstva dodatno se usložnjava ako imamo na umu recentna društvena nastojanja fokusirana na ranu seksualizaciju djece. Koliko je teško biti i dijete i roditelj u ovoj eri zaglušujuće buke međunarodnih organizacija i produženih im ruku koje, brinući se o zaštiti najboljeg interesa djeteta, zajamčenog brojnim međunarodnim dokumentima, taj isti najbolji interes podređuju interesima odraslih i to onih odraslih koji teže nekom novom, izvitoperenom sustavu vrijednosti? Slobodno možemo reći, stvarnost nam je čak u znaku ekstremnog kršenja standarda najboljeg interesa djeteta $\mathrm{i}$ to na brojnim razinama i u brojnim aspektima života. Takva strategija kao da je za cilj postavila - imati u konačnici zbunjenu djecu,

1 Poznati obiteljski terapeut i programski voditelj međunarodne organizacije Familylab International (FLI), koja je posvećena razvoju obiteljskih kompetencija.

2 "Odnos s djetetom nije jednosmjeran. Djeca ne trebaju samo primati to što im mi dajemo nego i mi trebamo primati što nam djeca daju, i ono dobro i ono loše," kaže Juul. Naime, “... većina roditelja misli da je malu djecu potrebno odgajati, a djeci je, međutim, potrebno empatično vodstvo. Možemo slobodno na djecu gledati kao da su s drugog planeta. Djeca ne poznaju naš svijet i zato im je potrebno vodstvo", Jasper Juul \& Monica Qien, “Prostor za obitelj”, Familylab:hr, 2011., str. 19 i 148. 
raspiriti im maštu nečim suvremenim, trendovskim, nečim za što do sada nije bilo razumijevanja ili o čemu se šutjelo, a sve to u razdoblju kada se ta ista djeca traže, preispituju, kada se formiraju. Cilj je potaknuti ih na takva promišljanja koja će na raznolike načine zaintrigirati njihovu dječju maštu, posvijestiti im nešto što se do sada čuvalo skriveno iza mračne koprene vjerskih, konzervativnih, nazadnih i kakvih li sve ne ideja i ideologija, kako to neki vole istaknuti. Kao vrlo učinkoviti mehanizmi za 'vađenje istine' na svjetlo dana, poslužili su suvremeni odgojno-obrazovni sustavi, koji su, uz obitelj, od ključne važnosti u odgoju i podizanju djece. Čak i oni namijenjeni predškolskoj, "vrtićkoj' dobi, iznimno su "progresivni i suvremeni". Nastoje prosvijetliti djecu na različite načine: putem igračaka ${ }^{3}$ koje su daleko od nekadašnje lutke, autića i sl., nadalje, putem crtanih filmova koji više nalikuju 'crtićima' za odrasle iščašenih potreba (obiluju prostotama, svekolikom vulgarnošću, nasiljem), ${ }^{4}$ putem slika dostupnih na uličnim panoima, na TV-u, ${ }^{5}$ točnije u dnevnom boravku gdje je dijete, u trenucima, pa i kraće roditeljske odsutnosti, u prilici vidjeti štošta neprirodnog, zbunjujućeg, nadalje, putem slikovnica i knjiga namijenjenih djeci, ${ }^{6}$ kasnije putem školskih programa zdravstvenog odgoja, spolnog odgoja koji su, u načelu, dobrodošli, ali služe nerijetko i za provlačenje materijala neprimjerenih djetetovoj dobi i zrelosti, u pravilu ideološki ${ }^{7}$ obojenih, zatim lektira i udžbenika pa do poduka u vidu predavanja i drugih načina djelovanja raznoraznih udruga. Pri tome nerijetko se posegne i za angažmanom čak i inozemnih studenata koji, kroz

3 U posljednje vrijeme često smo u prilici čuti kako pojedine europske države traže da se stane na kraj "rodno stereotipnim igračkama". Nameće se rodna ideologija djeci, i to onoj najmlađoj. Vidi: Judi Mesman in Dutch media on gender neutral toy stores, https://www.universiteitleiden.nl/en/news/2019/10/ judi-mesman-on-gender-neutral-toy-stores (preuzeto 30. X. 2019.).

4 Kao primjer možemo navesti dječju emisiju "Juhuhu" u kojoj se djeci prikazuju tijela ispod pojasa, u prilici su sresti se s gestikulacijom, kretnjama i načinom govora koji se pripisuje feminiziranim homoseksualcima. I što je jako bitno, radi se o simpatičnim likovima koje djeca rado oponašaju. Ili, na inozemnim TV-programima koji su (nažalost) dostupni djeci, 19. II. 2018. prikazan je i 'crtić' pod nazivom Extreme vaginal makeover. Djeca su, uz trenutke izostanka nadzora odraslih, u prilici te i takve stvari gledati, htjeli mi to priznati ili ne.

5 Primjerice, HRT-ov portal "Projekt Drugi" (https://projektdrugi.hrt.hr) koji je namijenjen upravo djeci i mladima školskog uzrasta te njihovim nastavnicima, učinio je dostupnim videa kojima se promovira posvajanje djece od strane istospolnih osoba, te se negativno predstavljaju osobe koje se ne slažu s homoseksualnim načinom života. Naime, one koji ne podržavaju zatjeve LGBT osoba svrstavaju u kategoriju nasilnika, homofoba, pri tome prikazujući homoseksualce kao njihove žrtve. S tim u svezi, nameće se i rodna ideologija djeci. Na to je svojedobno reagirao CitizenGo, zajednica građana koja aktivno promiče učešće društvene zajednice u politici, zalažući se za dobro društva i država, štiteći život, obitelj, temeljna ljudska prava. Isti, sasvim opravdano, u ovome razaznaju plasiranje jednoumlja i manipulaciju djecom uz neuvažavanje rezultata najnovijih znanstvenih istraživanja koja ukazuju na znanstvenu neutemeljenost i opasnost rodne ideologije, vidi: https://citizengo.org/hr/ed/41330-zaustavimo-hrt-ovonametanje-lgbtq-propagande-djeci (preuzeto 19. II. 2019.).

6 Koliku pažnju pošast rodne ideologije zavređuje, dovoljno govori i ne tako davno (2016. godine) obranjena doktorska disertacija na Fakultetu za filologiju Univerziteta u Beogradu, dr. Jelene B. BabićAntić: "Rodni stereotipi i jezička sredstva u funkciji formiranja rodnih ideologija dece kao čitalačke publike romana Harry Potter, autorice J. K. Rowling na engleskom i u prevodu na srpski jezik" (Gender Stereotypes and Linguistic Means in the Function of Forming Gender Ideologies Among Children as Readers of the Harry Potter Novel by Joanna K. Rowling in English and Serbian).

U političkom i sociološkom smislu, počevši od 19. st., pojam "ideologija” općenito se shvaća kao nešto suprotno od povijesti i znanstvene utemeljenosti, kao konstrukcija društvenih ideala koje treba politički ostvariti. Tako: Anto Mišić, Rječnik filozofskih pojmova, Verbum, Split, 2000., str. 115. 
razne europske programe studentskih razmjena, obilaze hrvatske osnovne i srednje škole sa zadatkom educiranja i širenja vidika hrvatskoj mladeži koju i po ovim temama treba približiti suvremenom svijetu. Pa se, u tu svrhu, kao tema predavanja, popraćena istoimenim filmom, navede, primjerice, "depresija", a pri tome osnovu predavanja čini ništa drugo do li poduka na planu snažnije seksualizacije djece, točnije, pitanja propitivanja vlastite spolnosti, spolne orijentacije, istospolnosti kao najnormalnijeg životnog odabira, a onda tek pred kraj poduke pojavi se i tema depresije - ali tek kao posljedica nepronalaženja i nesnalaženja djeteta glede vlastite spolnosti, a sve zbog nedovoljne ili uskraćene edukacije. Razne vrste školskih odgoja nastoje im približiti sve ono što je prirodno, pače nužno da blagovremeno saznaju kako ne bi bili prikraćeni za segment prihvatljivosti svih oblika i vidova eksperimentiranja po seksualnoj osnovi, a onda time i pitanja vlastite spolne, ali i rodne pripadnosti.

Čak i uz pretpostavku da je riječ o roditelju koji udovoljava svim zahtjevima što ih pred njega postavlja standard roditeljske skrbi, zbunjenost i nesnalaženje roditelja u tom društvenom, pa time i odgojno-obrazovnom neredu, posve je očekivana. U toj bitki s neravnopravnim omjerom snaga, kada na suprotnoj strani imamo međunarodnu zajednicu u ulozi fanatičnog "popravljača svijeta", ${ }^{8}$ roditelj gubi bitku. A "fanatik", kaže izraelski književnik Amos Oz, “... neumorno radi na tome da te poboljša i unaprijedi, da ti otvori oči, tako da i ti možeš vidjeti svjetlo ... mnogo se više zanima za tebe nego za sebe. Danonoćno se trudi izbaviti te iz magle i povesti u smjeru velikog svjetla, jednom i zauvijek spasiti te od pogrešaka, ... on u svako doba juri da ti se objesi oko vrata i spasi te jer te silno voli, voli te bezuvjetnom ljubavi ... Postoje brojni fanatici koji teže što prije promijeniti zbunjeno čovječanstvo ne bi li ga spasili od sebe samoga, a među njima su mnoge skupine radikalnih popravljača svijeta koji primjenjuju silu". ${ }^{9}$ Dodali bismo tome, silu nastalu u odnosu pozicija moći (à propos međunarodne zajednice; međunarodnih organizacija, centara svjetske moći) koja svojim brižno pripremanim, minucioznim radom na dugogodišnjim projektima, a onda i dokumentima, strpljivo stvara neku novu sliku stvarnosti u kojoj oni koji bi trebali biti kategorija na samom vrhu piramide ljudskih prava djeca, nađu svoje mjesto u njezinu podnožju, služeći tek kao sredstvo za stvaranje nekog "boljeg svijeta". ${ }^{10}$ Nema tog boljeg svijeta dok god su najranjiviji i najslabiji

8 Koristimo ovu zanimljivu sintagmu o čijoj slojevitosti (u drugačijem kontekstu) lijepo progovara izraelski književnik Amos Oz u svojoj knjizi "Shalom La'kana'im” ili "Pozdrav fanaticima”, Fraktura, 2018., str. 13-45. "Možda je jedan od razloga za val rastućeg fanatizma sve jača žeđ za jednostavnim i brzim rješenjima, za 'instant' spasenjem”, navodi A. Oz (str. 21). U našem kontekstu, ne razaznajemo spasiteljsko poslanje, dapače, isto je rušilačko, devastirajuće do kraja.

9 Amos Oz, str. 28-29.

10 Nadalje, na jednom mjestu Amos Oz kaže “... slijepo slijeđenje neke ubilačke ideologije ... nužno podrazumijeva ... i sljedbenika koji odustaje od vlastite samostalnosti”, str. 26. U našem slučaju riječ je o cijelom spektru prisilnih sljedbenika u vidu roditelja, odgojitelja, učitelja i sl. kojima se oduzima vlastitost i samostalnost (roditeljska, odgojna, pedagoška, ljudska...) i djetetu-žrtvi nametnutih igrarija "fanatičnih popravljača svijeta”. Dragovoljne sljedbenike popravljača svijeta prepoznajemo u pojedinim vladajućim nacionalnim garniturama koje se ne libe odricanja i vlastitog naroda i njegove dobrobiti prihvaćajući slijepo diktate međunarodne zajednice, upravo nerijetko ignorirajući volju vlastitog naroda. U eri tzv. posvemašnje demokracije, rekli bismo da se ista osjeća tek u tragovima. 
tek moneta za potkusurivanje na tržištu strahota suvremene civilizacije. Nema tog boljeg sutra u eri dezintegracije obitelji, u eri otimanja roditeljima onoga što im pripada od iskona, a to je pravo na odgoj vlastite djece. Nema boljeg svijeta u eri kada osnovni životni uvjeti za normalan rast i razvoj podmlatka (često upakirani u floskule, tipa održivog razvoja) znače, zapravo, glad, štetnu prehranu, bolesti, okoliš kao prijetnju, da ne govorimo o povredama fizičkog i psihičkog integriteta djece (postojanju "djece rata", djece nasilja i neprimjerenog rada, spolnog iskorištavanja, ropstva, trgovine organima). ${ }^{11}$

U svakom slučaju, strpljivi rad na postizanju otuđenja od stvarnosti nekako stremi k najgnusnijem - seksualizaciji djece, a što je još bolnije, ali je, očigledno, najučinkovitije, kroz kanal osuvremenjenih odgojno-obrazovnih modela.

Već je i papa Benedikt XVI. upozoravao da smo “... doista suočeni s globalnom 'antropološkom revolucijom' koja napada same korijene ljudske egzistencije. Ta revolucija ima pet političkih ciljeva: ukloniti očinstvo i majčinstvo; uništiti obitelj; ozakoniti pobačaj; ozakoniti homoseksualni ‘brak' koji bi uključivao posvojenje djece i medicinski pomognutu oplodnju te raditi na seksualizaciji djece kroz obveznu opsežnu seksualnu edukaciju". ${ }^{12}$

Suvremeni odgojno-obrazovni modeli trebali bi biti prvenstveno usmjereni na pismenost, životno nužnu, nasušno potrebnu pismenost djece (građansku, kulturnu, odgojnu, jezičnu, političku, financijsku). To je ono što je, uz obitelj, mir među narodima i državama, zdrav okoliš i hranu, potrebno djeci svijeta.

\section{2. “DOPRINOS” MEĐUNARODNE ZAJEDNICE NA PODRUČJU SUVREMENE PUERIKULTURE}

\subsection{Ujedinjeni narodi}

Ujedinjeni narodi i neke od njegovih specijaliziranih organizacija i agencija ponašaju se, sve otvorenije, kao da su dobili mandat razraditi koncepciju ljudskih prava koja se korjenito razlikuje od one izražene 1948. godine u Općoj deklaraciji o ljudskim pravima. "Opća deklaracija je antropocentrična. Ona priznaje da je u središtu svijeta i vremena čovjek, razuman, slobodan, odgovoran, sposoban za solidarnost i za ljubav.

Od sada, prema UN-u, čovjek je tek prolazna čestica u svemiru. Više se ne nalazi u središtu vremena otvorenog prema onostranosti; on je proizvod evolucije, stvoren je za smrt. Više nije osoba, nego pojedinac, više ili manje koristan, u potrazi za užicima... To je glavni izvor takozvanih 'novih ljudskih prava'. Više nisu ni priznata ni objavljena; o njima se pregovara ili ih se nameće. Njima se trguje. Ona su izraz volje jačega. Nova ideologija koja podrazumijeva ta takozvana 'nova prava'

11 Josip Mužić, „Rat protiv čovjeka“, Glas Koncila, Zagreb, 2015., str. 43-58.

12 Genderism - a new ideology destroying the family, https://www.lifesitenews.com/opinion/ genderism-a-new-ideology-destroying-the-family (preuzeto 18. IX. 2018.). 
jest holistička. Sve je u svemu: čovjek postoji samo zato što je dio Zemlje-Majke, Geje, kojoj se mora klanjati. Čovjek, dakle, mora prihvatiti stegu što mu je nameće ekosustav koji ga nadilazi. Morat će prihvatiti nadnacionalnu tehnokraciju koja, izmišljajući svoje 'prosvjetiteljstvo', državama nameće što im je činiti, a pojedincima što im je misliti. Upravo, uvjeren kako je nositelj novoga 'prosvjetiteljstva', UN je stao na čelo pothvata bez presedana: to je ideološko pripitomljavanje. Pri tome, sve teme se artikuliraju oko dva pola: holizma, koji znači uništenje tradicionalnog antropocentrizma, i takozvanih novih ljudskih prava, koja proizlaze iz konsenzusa individualističke aritmetike probitaka i užitaka". ${ }^{13}$

Takvu sliku stvarnosti možemo pratiti i kroz događanja u kojima se kao sredstvo pojavljuje Konvencija UN-a o pravima djeteta. ${ }^{14}$ Ista člankom 3. st. 1. jasno propisuje da u svim aktivnostima koje radi djece poduzimaju javne ili privatne ustanove socijalne skrbi, sudovi, upravne vlasti ili zakonodavna tijela, interesi djeteta trebaju imati prednost. Države stranke obvezuju se da će kroz odgovarajuće zakonodavne i upravne mjere osigurati zaštitu djeteta i skrb kakva je potrebna za njegovu dobrobit uzimajući u obzir prava i dužnosti roditelja, zakonskih skrbnika i osoba koje su zakonski odgovorne za dijete (v. čl. 3. st. 2. Konvencije).

Dobra intencija Konvencije kao da gubi trku s vremenom, postaje mrtvo slovo na papiru. Od te 1989. godine kada je ugledala svjetlo dana do danas, definitivno smo se dobrano odmaknuli od svakog vida puerikulture, što neminovno utječe i na promjene glede dobra čovječanstva i budućnosti. Zabrazdili smo u blatu dehumanizacije. Zastranili smo toliko da se priča o dobrobiti i najboljem interesu djeteta iz 1989. po Konvenciji koja je interese djeteta opravdano uzdignula na razinu nadprava u odnosu na svijet odraslih, a sada se definitivno pretvorila u svoju suprotnost. Interesi i dobrobit djeteta kao da gube svaku priliku u duelu sa svijetom odraslih koji mu je namijenio neke nove puteve odrastanja, koji podrazumijevaju podvođenje djece interesima i dobrobiti odraslih. Odraslih, utjecajnih, onih koji su produžene ruke svjetskih centara moći, ujedinjenih u zacrtanom cilju i metodologiji ostvarenja istoga, u kojima prepoznajemo učitelje koji zastraniše, a o kojima je govorio još sv. Pavao u poslanici Timoteju. ${ }^{15}$ Međutim, za razliku od onovremenih

13 U halucinantoj holističkoj svaštarnici svaka tema upućuje na sve druge kao u igri zrcala. Pogledajmo: siromaštvo upućuje na pučanstvo, ono na 'održivi razvoj', od njega se ide na okoliš, pa dalje na sigurnost prehrane, od nje na ‘javno zdravstvo' kod kojega zdravlje društvenog tijela ima prednost pred zdravljem osoba, dalje na eutanaziju, od nje, pak, na nove oblike eugenizma, s njih na radikalni feminizam, od njega na 'rod' (gender), pa na obitelj, pa na 'reproduktivno zdravlje', od toga na pobačaj, od njega na temeljnu zdravstvenu zaštitu, od nje na seksualni odgoj, a od njega na 'nova ljudska prava', s njih na homoseksualnost, od nje na uklanjanje primjedbi koje bi mogle doći od nacionalnih vlada koje se ne slažu, od toga na prokazivanje 'novih oblika netolerancije', od toga na nove sudove, od njih na osnaživanje uloge i moći UN-a, od toga na promjenu nacionalnih zakonodavstava, od njih na povećanje sredstava kojima raspolažu međunarodne agencije, od toga na uvjete za davanje 'pomoći', od toga na uključivanje nekih nevladinih organizacija u programe agencija UN-a, od toga na učvršćivanje konsenzusa... itd: vrtimo se u krugu... Holizam obvezuje: doista, sve je u svemu. Tako: Michel Schooyans, Skriveno lice UN-a-Prema novoj svjetskoj vladi, Verbum, Split, 2006., str. 10-13.

14 Konvencija UN-a o pravima djeteta, Službeni list SFRJ, br. 15/1990., Narodne novine Međunarodni ugovori, br. 12/1993. i 20/1997., 4/1998., 13/1998., 5/2002., 7/2002., 2/2003., $2 / 2017$. 4/2017.

15 Novi zavjet, Prva poslanica sv. Pavla Timoteju, http://biblija.ks.hr/knjiga.aspx'g=61 (23. I. 2019.). 
“... lažnih učitelja koji su promašili i zastranili u praznorječju; koji su htjeli biti učitelji Zakona, a nisu razumjeli ni što govore ni što tvrde", kako je to sv. Pavao govorio, ovi današnji učitelji koji su se odazvali pozivu učitelja, prosvjetitelja novog svjetskog poretka i te kako znaju što, zašto i kako podučavaju današnju djecu i mladež nekim novim suvremenim vrijednostima, upotrebom nekog novogovora, meta-jezika, koji, upravo u ovoj eri jezikoslovne igraonice, podrazumijeva brisanje iz rječnika i iz života obitelji oca i majke, muškarca i žene (spolnih različitosti), ${ }^{16} \mathrm{a}$ sve u ime nekih novih jednakosti i ravnopravnosti.

Riječ je o ideologiji roda kojom su, kako to lijepo kaže M. Schooyans, "prožeti svi kotačići UN-a", ${ }^{17}$ a kojom se prvenstveno želi zamagljivati vid djeci, zbunjivati ih u tom najosjetljivijem životnom razdoblju - djetinjstvu koje, samo po sebi, obiluje pitanjima, dvojbama, traganjem, bojazni...

Američko udruženje pedijatara ${ }^{18}$ svojedobno se izjasnilo o štetnosti rodne ideologije za djecu i to po osam točaka. 1) norma za oznaku ljudskih svojstava mora biti muško ili žensko. Ljudska je seksualnost binarna sa svrhom reprodukcije. Vrlo su rijetki poremećaji razvoja spolova (DSD), i svi su medicinski prepoznatljivi kao odstupanje od seksualno binarne forme i s pravom se tretiraju kao poremećaj. Osobe s DSD-simptomima (koji se nazivaju i interseksualnim) ne predstavljaju treći spol. 2) Nitko se ne rađa s rodom, već s biološkim spolom. Nitko se ne rodi sa svijesti kao muškarac ili žena, već se ta svijest razvija tijekom vremena poput svih razvojnih procesa. Ona može biti i istisnuta iz subjektivne percepcije, odnosa i neželjenih iskustava djeteta u ranom djetinjstvu. Međutim, ni takve osobe nemaju treći spol. Oni ostaju biološki muškarci ili žene. 3) Vjerovanje osobe da jest ono što nije ili da nije ono što jest, u najboljem slučaju, znak je poremećenog ponašanja. Kako bi inače zdravi biološki dječak smatrao sebe djevojčicom ili obrnuto? Tu postoji objektivni psihološki problem u svijesti, a ne u tijelu i na taj način mu treba i pristupiti. Kažemo da ta djeca pate od tzv. rodne disforije i ista je prepoznata kao mentalni poremećaj i u najnovijem izdanju dijagnostičkog i statističkog priručnika Američkog udruženja psihijatara. 4) Pubertet nije bolest, a hormoni koji blokiraju (povratno i nepovratno) pubertet dovode do stanja bolesti - odsutnost puberteta - naime, koče rast i spolnost u ranije biološki zdravom djetetu. 5) Sukladno stajalištu Američkog udruženja psihijatara, čak 98 posto spolno zbunjenih dječaka i 88 posto spolno zbunjenih djevojčica, nakon prirodnog tijeka prolaska kroz pubertet, prihvaćaju svoj biološki

16 Glede spolne/biološke različitosti muškarca i žene, Jordan B. Peterson kaže “... unatoč opsežnoj, multidisciplinarnoj znanstvenoj literaturi koja ukazuje na to da su razlike među spolovima snažno uvjetovane biološkim čimbenicima za Derridu (Jacques Derrida, francuski filozof, vođa postmodernista, koji je ušao u modu kasnih 70-ih. Sam je za svoje ideje govorio da predstavljaju radikalizirani oblik marksizma) i njegove postmoderne marksističke akolite znanost je samo još jedna igra moći koja iznosi tvrdnje kojima se okorišćuju oni na vrhu svijeta znanosti. Činjenice ne postoje”, Jordan B. Peterson, "12 pravila za život-protuotrov kaosu”, Verbum, Split, 2018., str. 320 i 325. 87.

17 Michel Schooyans, Skriveno lice UN-a-Prema novoj svjetskoj vladi, Verbum, Split, 2006., str.

18 American College of Pediatricians: Gender Ideology Harms Children, Updated September 2017, https://www.acpeds.org/the-college-speaks/position-statements/gender-ideology-harms-children (preuzeto 4. XI. 2019.). 
spol. 6) Djeca u predpubertetskoj dobi s utvrđenom spolnom disforijom mogu dobiti blokatore puberteta u jedanaestoj godini te će u kasnijoj adolescenciji morati uzimati tzv. unakrsne spolne hormone kako bi nastavila oponašati suprotni spol. Takva djeca nikada neće moći začeti ni na koji način genetski određenu djecu (čak ni putem reproduktivne tehnologije). Također, tzv. unakrsni spolni hormoni dovode se u vezu s brojnim zdravstvenim rizicima (srčane bolesti, problemi s krvnim tlakom, sklonost krvnim ugrušcima, srčanom udaru, dijabetesu i karcinomu). 7) U Švedskoj, koja najviše promiče LGBTQ-ideologiju, broj suicida je oko dvadeset puta veći među odraslima koji koriste tzv. unakrsne spolne hormone i podvrgavaju se određenim krirurškim zahvatima promjene spola. ${ }^{19}$ Koja će razumna osoba koja ima osjećaj samilosti osuditi malu djecu na takvu sudbinu znajući da će nakon puberteta 88 posto djevojčica i 98 posto dječaka prihvatiti realnost i postići stanje mentalnog i tjelesnog zdravlja? 8) Uvjetovanje i poticanje djece da poklone povjerenje životu iza kojeg stoje kemija i kirurški zahvati za postizanje lažnog spola nije ništa drugo do li zlostavljanje djece, zaključuju mjerodavni iz dvaju spomenutih američkih udruženja: pedijatrijskog i psihijatrijskog.

U Europi, primjerice, u Ujedinjenom Kraljevstvu, tisuću roditelja 'transidentificirane' djece moli liječnike da ih poslušaju. Riječ je o online-skupini koja se pismom obratila AAP-u (American Academy of Pediatrics). Osvrću se na politička nastojanja na planu osiguravanja sveobuhvatne skrbi i podrške transrodnoj i 'rodno drugačijoj' djeci u adolescenciji ${ }^{20}$ te navode da su duboko zabrinuti zbog toga što kliničari koji koriste prihvaćenu terapiju nenamjerno nanose psihičku i fizičku štetu à propos smjernica koje je AAP donio, a koju će mnoga djeca i mladež koja su 'transrodno prepoznata' i te kako osjetiti. Ističu kako je u prethodnoj dekadi vodstvo pripadalo muškoj djeci, a sada pripada djevojčicama-pacijenticama. Navode taj porast od 4400 posto u odnosu na prethodnu dekadu (Rayner, 2018.). Naime, drastičan porast broja takve djece i predominacija djevojčica potakao je i britansku Vladu da pokrene istragu zbog zabrinutosti da bi povećanje od 4400 posto u posljednjem desetljeću moglo biti posljedica društvenog fenomena. Takva medikalizacija njihove 'rodne neusklađenosti' u okruženju temeljenom na rodnim stereotipima, homoseksualnosti i/ili mentalnim bolestima predstavlja ozbiljnu štetu djeci u njihovoj trans-identifikaciji.

Liječenje agonistom hormona koji oslobađa gonadotropin, kao vrstom lijekova koji utječu na gonadotropine i spolne hormone, producira ozbiljne dugoročne

19 Slično je i u mnogim državama SAD-a. LGBTQ-lobi roditeljima preporučuje potporu i afirmaciju transrodnog putovanja njihova djeteta kao nužnost u sprečavanju istoga da pokuša suicid. No, upravo brojnost suicida u takvim slučajevima govori da podrška djetetovoj promjeni spola predstavlja dodatni pritisak na dijete umjesto da ga umanjuje. Liječnici priznaju da nemaju znanstveno utemeljenje za svoje preporuke za djecu s rodnom disforijom. U igri "odaberi spol", $45 \%$ njih pokušat će počiniti suicid. Naime, utapanje u moru psiholoških, emocionalnih i društvenih problema preduboko je da bi ih iz istog izvukle nove zamjenice. Tako: Walt Heyer, Doctors Admit They Don't Know Which Kids Should Gender Transition But Do It To Them Anyway, The Federalist, July 10, 2017, https://thefederalist.com/2017/07/10/ doctors-admit-dont-know-kids-gender-transition-yet-anyway/ (preuzeto 5. XI. 2019.).

20 Ensuring Comprehensive Care and Support for Transgender and Gender-Diverse Children an Adolescence, Rafferty et al., 2018. 
posljedice po zdravlje kostiju, potencijalno je opasno za neurološko zdravlje i sterilizira dijete. Štete od hormonske terapije dobro su znane, uključujući i kardiovaskularne bolesti koje postaju sve više predmetom sudskih postupaka i to kod odraslih osoba koje nisu transrodne. Štete od operacija očigledne su i nepovratne, što je dodatno problematično kada se mladi pojavljuju u ulozi pacijenata. Oni mijenjaju svoje mišljenje i, barem kod glavnine, takva su razmišljanja tek dio prolaznosti odrastanja. ${ }^{21}$

No, vrijeme u kojem živimo vrijeme je ideologije roda koja neupitno teži društvu bez razlike između spolova. Njome se biološki spol kao prirodna datost s jedne strane, i društveno-kulturna uloga spola (koja bi se mogla nazvati 'rodom') pokušavaju odijeliti, a s ciljem ukidanja svih razlika između muškaraca i žena, ostvarenja denaturalizacije spolova. Dovoljno je htijenje, želja pojedinca da bude ono što hoće i kad hoće, a sve pod parolama prava na izbor, jednakost, nediskriminaciju. ${ }^{22}$

Međutim, to nosi dodatni uteg kada djeca postaju i sredstvo i žrtva takve ideologije. Naime, kroz raznorodne vidove indoktrinacije tijekom odrastanja, a počev od najranijeg djetinjstva kroz domenu odgoja i obrazovanja, vlade diljem svijeta, kako ispravno zaključuje Lew Rockwell, ${ }^{23}$ žele preuzeti odgoj djece. Vladin odgoj bi, stoga, trebao predstavljati dokaz dobrote države i njezine brige za opće dobro. Pravo je objašnjenje zapravo manje laskavo. Naime, ako se vladina propaganda uspije zakorijeniti dok djeca još odrastaju, ta djeca više neće biti prijetnja državnom aparatu, već će sami stezati lance oko vlastitih članaka. ${ }^{24}$

Zamjetan je angažman UNICEF-a, poglavito od sredine devedesetih godina prošlog stoljeća, od kada intenzivnije radi na rodno utemeljenoj ideologiji. ${ }^{25}$ UNICEF Gender Action Plan, 2018-202126 smatra da je upravo na rodu utemeljena diskriminacija jedan od najčešćih oblika diskriminacije s kojom se djeca suočavaju (?!). ${ }^{27}$ Zahvaljujući brizi oko rodnih uloga, istovremeno zanemarujući postojeći Međunarodni dan djeteta, dobili smo Međunarodni dan djevojčica (International

21 Opširnije u: Madeleine Kearns, „A Thousand Parents of Trans-Identifying Children Beg Doctors to Listen“, National Review, The Corner-Health Care, October 24, 2018.

22 Opširnije, u: Dijana Jakovac-Lozić, ,'Rod' protiv 'spola' - polazište na putu razaranja braka i obitelji“, Zbornik radova Pravnog fakulteta u Mostaru, Petnaesto međunarodno savjetovanje "Aktualnosti građanskog i trgovačkog zakonodavstva i pravne prakse”, 2017., str. 135.

23 Llewellyn Harrison Rockwell, američki pisac, politički savjetnik, osnivač Ludwig von Mises Institute.

${ }^{24}$ Lew Rockwell's Libertarian Quotes, http://libertarianquotes.net/R/Lew-Rockwell.html (preuzeto 18.11.2019.).

25 U srpnju 2013. godine glavni tajnik UN-a Ban Ki-moon je rekao: "Kažem vam jasno i glasno, svatko ima prava kakva imaju i svi drugi. Homoseksualci, biseksualci, transrodne osobe, svi su oni rođeni slobodni i jednaki i ja stojim rame uz rame s njima u njihovoj borbi za ljudska prava", Eliminating discrimination against children and parents based on sexual orientation and/or gender identity, UNICEF - Current Issues, No 9, November 2014, https://www.unicef.org/videoaudio/PDFs/Current_Issues_ Paper-_Sexual_Identification_Gender_Identity.pdf (preuzeto 17. II. 2019.).

26 United Nations, Economic and Social Council, United Nations Children's Fund, Executive Board, Second regular session 2017, 12-15 September 2017, E/ICEF/2017/16.

27 About gender equality and UNICEF, https://www.unicef.org/gender/gender_57317.html (preuzeto 26. I. 2019.). 
Day of the Girl Child - IDG) koji se slavi 11. listopada. ${ }^{28}$ Pitamo se što je s Međunarodnim danom dječaka? Ili je za njih dovoljno da se zadovolje standardom djeteta?

Prava djece nemoguće je ispravno prosuđivati i tretirati u kontekstu rašomonskog pristupa 'temeljima' - braku i obitelji. Djeca su intrinzično, a njihova dobrobit je inherentno navezana za 'temelj' koji, u ovim vremenima i pod ovim prilikama, postaje teško shvatljiv i još teže prihvatljiv. ${ }^{29}$ Kako bi on postao ne pod svaku cijenu shvatljiviji, već bliži i prihvatljiviji, nužno se nameće potreba za 'širenjem vidika' u maglovitim prostranstvima ljudskoj vrsti pripadajućih prava ravnopravnosti i jednakosti i to kroz već poodavno domišljene, a u novije vrijeme i strpljivo razrađene modalitete edukacije za život. Znakovito mjesto u okviru suvremene edukacije djece i mladih pripada - ranom seksualnom prosvjećivanju djece.

Teže je nego li mislimo, osloboditi se diktatorskih oblika života. Svako vrijeme je nosilo i takvo breme. Međutim, “ ... nova diktatura je utoliko opasnija od prethodnih jer nastoji u svojoj neodgovornoj revnosti manipulirati s djecom i mladeži i moramo se, svjesni svoje odgovornosti, za njih pobrinuti" ${ }^{30} \mathrm{Ili}$, kako bi to jedan od uglednijih rimskih pravnika Paulus Iulius kazao: "Naš interes je da duh naše djece ne bude iskvaren". ${ }^{31}$ Teška zadaća stavlja se prvenstveno pred obitelj koja prolazi, kako smo rekli, kroz ozbiljnu krizu. Naravno, međunarodne institucije, koje bi trebale biti na braniku društvene jezgre (braka), a samim tim i društvene stanice (obitelji) provode upravo politiku koja odnemaže obitelji i to do takve mjere da obitelj “... čak ni ne predviđaju za svoga sugovornika, već se žele obraćati samo pojedincima". ${ }^{32}$ To je sada već sasvim razvidno i kroz djelovanje UN-a (i mnogih njegovih agencija) koji “... danas radije izbjegava to sučeljavanje s duhom i slovom svojih početaka". ${ }^{33}$ Stalno se zagovara tobožnji konsenzus, ali samo zato da bi se stalo iznad nacionalnih zakonodavstava koja se, pak, najčešće nastavljaju pozivati na objektivnost ljudskih prava kako su ona shvaćena u klasičnoj tradiciji. ${ }^{34}$

Poznato je da je u okviru Agende za održivi razvoj 2030 ${ }^{35}$ već nekoliko godina na snazi novi UN-ov program mjera koje bi trebale obilježiti i narednu dekadu, a među svojim ciljevima ${ }^{36}$ ima i one koji idu za "osiguranjem zdravlja i blagostanja svih ljudi s pravom na kvalitetno obrazovanje i rodnu ravnopravnost". Jedan segment kvalitetnog obrazovanja i rodne ravnopravnosti podrazumijeva, sada već

28 (A/RES/66/170) str. 147.

29 Dijana Jakovac-Lozić, "Rod” protiv "spola" - polazište na putu razaranja braka i obitelji, op. cit.,

30 Christa Meves, Kinderschicksal in unsere Hand (Erfahrungen aus der psychagogischen Praxis), Verlag Herder Freiburg im Breisgau, 15. Auflage 1995, str. 46.

31 “Interest nostra animum liberorum nostrorum non corrumpi”, (Paulus - Dig. 11, 3, 14, 1).

32 Josip Mužić, „Rat protiv čovjeka“, Glas Koncila, Zagreb, 2015., str. 16.

33 Michel Schooyans, Skriveno lice UN-a-Prema novoj svjetskoj vladi, Verbum, Split, 2006., str. 45.

34 Op. cit., str. 47.

35 Transforming our World: Agenda for Sustainable Development 2030, United Nations, 2015.

36 Sustainable Development Goals, United Nations, http://www.un.org/sustainabledevelopment/ sustainable-development-goals/, 17. I. 2019. 
evidentno, i edukaciju djece sa znakovitim naglaskom na nastojanjima za ranom seksualizacijom (CSE), ne ostavljajući im ni vremena ni prostora da se kroz vlastito formiranje i odrastanje opredjeljuju, grade vlastite stavove, prihvaćaju sebe i druge zato što su takvi, a ne zato što su podučeni tko su oni i tko su oni drugi.

$\mathrm{U}$ tom smislu, Comprehensive Sexuality Education (CSE) jedna je od podmuklijih alatki koja se koristi diljem svijeta kako bi uništila zdravlje i nevinost djece. Živimo u vremenu nemilosrdne, stalne bitke nametanja CSE-a u političke arene, zakonodavstva, škole, živote djece i odraslih.

Općenito, UN na razne načine nacije čini slabijima. Na međunarodnim se skupovima postiže konsenzus uz pomoć sigurnih nevladinih organizacija koje obavljaju posao lobiranja. ${ }^{37}$ Pri tome, svakako posebno mjesto zavređuje Međunarodna federacija za planirano roditeljstvo - International Planned Parenthood Federation (IPPF), dežurni demografski policajac. ${ }^{38}$

A jedna, pak, od poznatijih organizacija koja se bori protiv ozbiljnijih prijetnji CSE-a djeci današnjice jest Family Watch International (FWI). ${ }^{39}$ Ista prepoznaje i ukazuje na ozbiljnu prijetnju djeci koja se iščitava iz izvatka objava IPPF-a te, kako smo kazali, jedne od nevladinih organizacija i agencijskih partnera UN-a, koja se bavi pitanjima pružanja usluga zaštite seksualnog i reproduktivnog zdravlja s naglaskom na slobodi pojedinca na vlastiti izbor te se općenito bori za zaštitu seksualnih prava. Iza floskule "planiranog roditeljstva" stoji bolesna potreba mijenjanja postojeće slike stvarnosti i obitelji kao njezine nositeljice (pri tome, imajući na umu, primjerice, angažman IPPF-a na smanjenju plodnosti, financiranju kontracepcije, pobačaja, sterilizacije, ohrabrivanju porasta homoseksualnosti, uvođenju poreza na djecu, ukidanju poreznih olakšica za obitelj, stavljanju supstancija za kontrolu plodnosti u pitku vodu, te prisilne sterilizacije za one koji već imaju dvoje djece i sl. ${ }^{40}$ IPPF sebe, samodopadno i slavodobitno, čak proglašava "savješću $i$ vođom pokreta planiranja obitelji na nevladinu području”. ${ }^{41}$ Rezultat njegova rada očituje se i u kreiranju radikalne filozofije namijenjene pohodu na djecu svijeta. I to ne samo onu nerođenu.

Konkretni podaci svjedoče o infiltraciji CSE-a u sva područja suvremenog svijeta. Zasigurno, to je globalna agenda kojom se na podmukao način nastoji indoktrinirati djecu. Na ovakvu stvarnost reagiralo je, već spomenuto, Američko udruženje pedijatara koje ju je poistovjetilo s jednim od najvećih napada na zdravlje i nevinost djece.

37 Michel Schooyans, Skriveno lice UN-a - Prema novoj svjetskoj vladi, Verbum, Split, 2006., str. 48.

38 International Planned Parenthood Federation (IPPF), https://www.ippf.org/, 20. XII. 2018. Ideologija IPPF-a prožima sve programe CSE-a i politiku diljem svijeta.

39 Family Watch International (FWI) jest organizacija utemeljena prije dvadeset godina. Riječ je o neprofitnoj organizaciji koja djeluje u konzultativnom statusu s Ekonomskim i socijalnim vijećem kao jednim od glavnih tijela Ujedinjenih naroda. Radi na zaštiti i promicanju obitelji kao temeljne zajednice društva na međunarodnoj, nacionalnoj i lokalnoj razini kroz edukaciju, zastupanje i humanitarnu pomoć. Više o FWI: https://familywatch.org/ (20. XII. 2018.).

40 Više u: Josip Mužić, „Rat protiv čovjeka“, Glas Koncila, Zagreb, 2015., str. 178-182.

41 Op. cit., str. 180. 
Razmatrajući "Guidance document for the implementation of young people's sexual rights", ${ }^{42}$ uglavnom stvoren u IPPF-u, uz potporu dviju UN-ovih organizacija (UNESCO i WHO), postaju razvidni razmjeri zastupljenosti radikalne seksualne ideologije unutar međunarodne zajednice te podupiranje CSE-programa diljem svijeta. Već na samom početku teksta uočavamo manipulaciju kod poimanja i upotrebe kategorija: djeca, mlade osobe, mladež.

Konkretno, Smjernice predviđaju i promiču:

1. slobodu seksualnog izražavanja za djecu, pa se navodi:

1.1. “... mlade osobe (neovisno o dobi ... trebaju biti sposobne istraživati, doživljavati i izražavati svoju seksualnost na zadovoljavajuće i sigurne načine ...). To se može dogoditi samo kada su mladoj osobi seksualna prava priznata i zajamčena."

Na manipuliranje spomenutim pojmovima nailazimo već u prvim rečenicama. Smjernice mladim ljudima / mladeži smatraju osobe koje su navršile deset godina života. Iako vrijeme nastupa adolescencije, kao ukupnog pokušaja psihičke prilagodbe na stanje puberteta, točnije, na nova endogena i egzogena stanja s kojima se osoba suočava, nije jednostavno popratiti konkretnom životnom dobi djeteta, već se u stručnoj literaturi navodi da započinje oko 11.-13. godine i traje do 18.20. godine. ${ }^{43}$ A djetetom se smatra, prema Konvenciji o pravima djeteta, "svako ljudsko biće mlađe od 18 godina, osim ako se po zakonima primjenjivim na dijete punoljetnost ne stječe ranije (čl. 1. Konvencije). Naravno, ne propušta se ukazati na važnost takvih "prava" koja mladeži (neovisno o dobi) "moraju biti priznata i zajamčena". Nešto kasnije ćemo vidjeti da se s tzv. prvim razinama poduke (v. infra) započinje, ipak, već od 5. godine života (?!). Očigledno, s pripremom za turbulentno razdoblje adolescencije ne smije se kasniti. Čim prije, tim bolje. Nadalje:

u toč. 1.2. Smjernica stoji “... zakoni koji kriminaliziraju konsenzualnu seksualnu aktivnost između adolescenata mogu adolescente izložiti riziku ..." (?!).

\section{Smjernice dalje promiču pravo djece na seksualno zadovoljstvo:}

2.1. “... osiguravajući da svi mladi ljudi razumiju da imaju pravo na seksualno zadovoljstvo i različite oblike u kojima zadovoljstvo ostvaruju, a što je od primarne važnosti za njihovo zdravlje i dobrobit."

Kada ovo čitamo ne bismo više trebali imati dvojbi, a time ni 'čudnih' roditeljskih reakcija na teme koje više nisu strane ni hrvatskim odgojno-obrazovnim programima, a iz kojih se, nakon svega, dade iščitati koliko je bitno "naučiti djecu

42 Promotes Sexual Rights for Children, https://www. sexualityeducation.org/fulfil/?inf_contact_ke

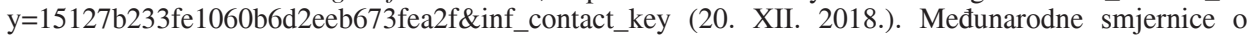
seksualnom obrazovanju objavio je UNESCO, u suradnji s UNICEF-om, UNFPA-om (United Nations Population Fund) i Svjetskom zdravstvenom organizacijom (WHO). One ne obvezuju, ali usmjeravaju i potiču političku volju u pravnom, točnije, zakonodavnom smjeru.

43 Usp.: Vlasta Rudan, „Normalni adolescentni razvoj“, Medix: specijalizirani medicinski dvomjesečnik, Vol. 10, br. 52, 2004., str. 36-39; Marina Kuzman, „Adolescencija, adolescenti i zaštita zdravlja“, Medicus, Vol. 18, br. 2, Adolescencija, 2009., str. 155-172 i dr. 
kako se zaštititi od neželjne trudnoće”. Naprosto, u svim tim i takvim odgojima nema ni spomena o životno pamtljivim dječjim simpatijama i prvim mladenačkim ljubavima. Naglasak je prioritetno na spolnom odnosu, na zadovoljstvu, uz poduku kako se ne zaraziti i ne zatrudnjeti. Istina, netko će reći, živimo u 21. st., djeca više nisu ista te je i to i te kako važno. Da, nisu ista jer je svijet u kojem žive, svijet odraslih (za njih odgovornih), upravo takav da se trudi svim silama krasti im djetinju nedužnost i prljati im mladenačku čistoću. Društvo iz godine u godinu briše razlike, gotovo pa tendira sve snažnijoj identifikaciji kategorije "djeteta" kategoriji "odrasle osobe", svjesno zanemarujući i apstrahirajući sve fizičke, psihološke i ine različitosti među njima. Djecu se zarana tretira kao odrasle osobe, uvjerava ih se da su dovoljno zrela da participiraju u svim društveno-hedonističkim podvalama pa se sukladno tome izlišnom čini i bilo kakva potreba za edukacijom takve naravi koja bi mogla utjecati na otklanjaje uzroka, već će se radije raditi na saniranju eventualnih posljedica. A kako i ne, ako međunarodna zajednica potiče djecu (točnije, "mlade ljude", ograničavajući se, za sada ${ }^{44}$ na djecu od 10 i više godina) na "seksualno zadovoljstvo" dajući mu snagu "prava", pri čemu nije izostala ni argumentacija naime, to je navodno "pravo" od "primarne važnosti za zdravlje i dobrobit djece" (v. supra). S druge strane, pak, ne možemo se oteti dojmu nezainteresiranosti te iste međunarodne zajednice za zdravlje i dobrobit djece u drugim segmentima života.

Međunarodna zajednica danas brojnim svojim aktivnostima, više nego ikada ranije, svjedoči o zatiranju i nepoštovanju digniteta djeteta i pripadajućih mu prava (dovoljno su strahotna njena nastojanja i istupi po pitanju prava na pobačaj, dovoljno je popratiti rasprave na temu poželjnosti pobačaja kad god to majka poželi; nadalje, osvrnuti se na retrospekcijski tijek i polučene rezultate te iste zajednice na planu odustajanja od vjekovne prevalencije braka žene i muškarca i tradicionalne obitelji kao najprirodnijeg i najvažnijeg dječjeg 'staništa' ${ }^{45}$ pa do prava na eutanaziju djeteta). Koliko više ima mjesta pozivati se na rimskog pjesnika

44 S obzirom na to da djeca danas sve ranije spolno sazrijevaju, za očekivati je da bi kroz određeno razdoblje, respektirajući benevolentnost međunarodne zajednice za ovaj aspekt života djeteta, mogla biti uklonjena sada postojeća donja dobna granica (od 10 godina). Tome u prilog, naime, govore i već postojeće poduke takve naravi i za djecu od pet godina (v. supra). Čak ako i zanemarimo modele vrtićkih igraonica (primjerice, tobogana u obliku falusa) za djecu mlađu od pet godina, a što se može vidjeti u vrtićima pojedinih europskih država.

Vjerujemo da bi se i za to lako iznašlo 'opravdanje' u vidu edukacijskog pokrivača i to, vjerojatno, kroz psihoanalitičku dimenziju tzv. 3. faze psihoseksulanog razvoja djeteta (u dobi od 3.-5. godine života), tzv. falusne faze, kada dijete nakon tzv. "oralne i analne faze" počinje otkrivati da ima (ili nema) falus (v. S. Gans, Freud's Psychosexual Stages of Development, https://www.verywellmind.com/freuds-stages-ofpsychosexual-development-2795962 (preuzeto 30. IX. 2019.).

$\mathrm{O}$ narativnim i figurativnim dječjim izričajima glede muško-ženskog spolovila, koja u kontekstu poticanja, valjda na kreativnosti temeljenoj, vrtićkoj poduci, ista sama modeliraju i oblikuju od raznih materijala; o tome da se od dječaka traži da određene dane dođu odjeveni u opravice djevojčica i obrnuto kako bi se zarana radilo na ravnopravnosti i uklanjanju razlika među spolovima, te ukazivalo na mogućnost lakoće 'biti nešto i netko po želji'; upućivalo da se djevojčice ne trebaju nužno igrati lutkama, već da je najnormalnije da to rade i dječaci i sl., gotovo da se čini suvišnim i govoriti. Dakle, glavnina tek ovlaš dotaknutog, na prvu, već mnogima nije ni čudna, a niti zabrinjavajuća. Rekli bismo - na prvu samo.

45 Više, u: Dijana Jakovac-Lozić, „Hrvatska obitelj u procijepu između tradicionalna poimanja i međunarodnih očekivanja“, Godišnjak Akademije pravnih znanosti Hrvatske, Vol. VIII, br. 1/2017., str. 1-33. 
Juvenala koji je davno rekao: "Najveće poštovanje dužni smo djetetu" (Maxima debetur puero reverentia) $)^{46}$, tj. valja paziti da spremajući ili radeći neko zlo ne sablažnjavamo djecu. Međunarodna zajednica se, pače, drznula ne samo okolišnim radnjama i posljedicama istih sablazniti djecu, već se djetetom otvoreno služi kao pukim probandom, kao sredstvom, a sve u obličju invokacijskog triptiha slobodatolerancija-demokracija.

3. Smjernice, dalje, promiču uporabu hormonalne terapije $i$ operativnih zahvata za djecu bez pristanka roditelja:

3.1. "Jamči se pristup hormonalnoj terapiji za transrodne i interseksualne ${ }^{47}$ adolescente ... bez potrebe za roditeljskim pristankom. Posebno zakonodavstvo bi, također, trebalo obuhvatiti pravo transrodnih i interseksualnih adolescenata da odlučuju o bilo kojim operativnim zahvatima na njihovim tijelima ...".

Istaknuto je, "bez potrebe za roditeljskim pristankom"(!?). Općenito, svjedoci smo vremena u kojem jača potreba za minorizacijom roditeljske uloge u odrastanju, odgoju, obrazovanju djece pa u datim trenucima i odlučivanju o nastavku liječenja, točnije, o životu i smrti (eutanaziji) vlastite im djece.

Svojedobno se moglo čuti: Ono dijete koje nema roditelja, postaje djetetom društva. To je jasno. Neupitna je i misao britanskog pedagoga i pisca A. S. Neilla ${ }^{48}$ kad kaže: "Dijete treba pustiti da odraste brzinom koja mu odgovara. Mnogi roditelji čine užasne pogreške pokušavajući djetetu nametnuti brzinu odrastanja". Sasvim jasno i prihvatljivo. Zasigurno, ima i takvih roditelja, bilo ih je i bit će ih, ali, vjerujemo, nisu česti. U tom slučaju, stoji ona Jungova: "Ako postoji nešto što želimo promijeniti kod djeteta, trebamo prvo vidjeti nije li to nešto što bi možda bolje trebalo promijeniti u nama samima". ${ }^{49}$ Međutim, danas svatko tko ne želi sklanjati pogled, prepoznaje opasnost na globaloj razini, onu kojom prijeti međunarodna zajednica (kroz odgoj, obrazovanje, općenito, kroz nametanje nekih novokomponiranih standarda dječje dobrobiti). Ona u zapučak smješta kategoriju roditelja, stavlja se ispred i iznad njih, namećući djeci upravo brzinu odrastanja. Nerijetko, na najodvratniji način. Njena uloga spram djece više nije pozitivno pokroviteljska. Ona više nije tu da štiti dijete i njegov interes.

46 Decimus Iunius Iuvenalis (rimski satiričar - pjesnik), Saturae, $(14,47)$.

47 Usp.: Naomi Schaefer Riley, Hormone therapy is a horrible risk for kids, June 20, 2017, https:// nypost.com./2017/06/20/hormone-therapy-is-a-horrible-risk-for-kids/ (preuzeto 4. XI. 2019.); Lawrence Meyer, Paul McHugh, ,Sexuality and Gender - Findings from the Biological, Psychological and Social Sciences", The New Atlantis, A Journal of Technology \& Society, 2016., https://www.thenewatlantis. com/publications/executive-summary-sexuality-and-gender (preuzeto 4. XI. 2019.); Ute Thyen, Hertha Richter-Appelt, Claudia Wiesemann, Olaf Hiort, Deciding on Gender in Children with Intersex Conditions, Treatments in Endocrinology, Vol. 4, Issue 1, February 2005, str. 1-8.

48 Alexander Sutherland Neill (1883. - 1973.).

49 Carl Gustav Jung (1875. - 1961.), psihijatar i psihoanalitičar, jedan od utemeljitelja analitičke psihologije.

"If there is anything that we wish to change in the child, we should first examine it and see whether it is not something that could better be changed in ourselves", https://www.brainyquote.com/quotes/carl_ jung_106972 (preuzeto 19. XI. 2019.). 
Osvrnimo se na trenutak na uradak W. Glassera, američkog psihijatra koji je knjigom The Quality School - Managing Students - Without Coercion ${ }^{50}$ jasno dao do znanja da je škola temeljena 'na izboru' škola gdje se svatko treba ponašati sukladno vlastitom odabiru, uz nužno snošenje i posljedica spram takvog odabira.

Međutim, nemogućim se čini identificirati 'izbor' djeteta (u paketu sa snošenjem i posljedica za takav izbor) s izborom odrasle osobe tj. roditelja djeteta. Ne samo što se roditeljske odgovornosti i dužnosti time transmitiraju na dijete, nego se stvara i dalekosežniji učinak, takvo nešto dovodi neminovno do konfuzije u poimanju i ulozi autoriteta.

S pravom se pitamo, kako to radi i M. Schooyans, ${ }^{51}$ ukazujući na zabrinjavajuće posljedice voluntarističkog i "konsenzualnog" tumačenja ljudskih prava, zamislivim li nam se čini brodolom tradicionalnog pojma dužnosti u kojem nitko više nikomu ne mora odgovarati? Ni to da sami roditelji više ne moraju odgovarati za svoju djecu čija "nova prava" - posebno na seksualno zadovoljstvo - moraju biti oslobođena od svakog roditeljskog prava na upletanje?

Zapravo, raznorodne agende međunarodne zajednice, davno osmišljene, u ovim vremenima melju sve pred sobom. Zajedničko im je to da sve idu za time da stvaraju nekakav vid "konfuzije", ili točnije, pomutnje, brkanje. Konfuzija se nalazi u osnovi svake od njih ("konfuzija spolova", "konfuzija autoriteta", "konfuzija rodova", "konfuzija uloga", "konfuzija identiteta" i sl.). Naprosto, "konfuzija" postaje i sredstvo i cilj.

4. Međunarodna zajednica, nadalje, Smjernicama promiče pobačaj. ${ }^{52}$

4.1. ... tako što ukazuje na nužnost “... liberalizacije zakonodavstva o pobačaju kako bi se omogućio svim mladim ženama (uključujući adolescentice) lakši pristup sigurnom pobačaju, bez roditeljskog pristanka ili pristanka bračnog druga".

Dakle, i ovo područje uključuje slobodu izbora i čini otklon od roditeljskog pristanka, ali i od pristanka bračnog druga. Rekli smo već ranije, međunarodna zajednica ne želi komunikaciju s obitelji, ona želi komunicirati samo s pojedincem. Pojedinac, neovisno o životnoj dobi i zrelosti, postaje sam po sebi, institucija.

K tome, zanimljivo bi bilo znati što uopće jest ili što se može nazvati "sigurnim pobačajem", postoji li uopće takav pobačaj koji je à priori "siguran"? Autor teksta, naglašavajući "sigurnost" čina djeteubojstva, vjerujemo, aludira na sterilne uvjete $\mathrm{i}$ obučeno osoblje (v. infra, 5.1. b) apstrahirajući, točnije, želeći odvratiti pozornost

50 William Glasser, The Quality School-Managing Students - Without Coercion, revised ed., Harper Perennial, New York, 1998.

51 M. Schooyans, op. cit., str. 41-42.

52 Dana 23. ožujka 2019. godine održano je zasjedanje UN-ove Komisije o statusu žena (CSW) koje je u prvi plan stavilo: slobodan pristup pobačaju za sve žene i djevojke, proglašavanje pobačaja ljudskim pravom, te uvođenje seksualnog odgoja, s naglaskom na ideološkom seksualnom odgoju u odgojnoobrazovne sustave. Dakle, u vremenu kada se mora moći zagovarati prioritetno pravo, ne samo navedenih, već i ostalih društvenih skupina, na život, na hranu, čistu vodu, na zdravstvenu skrb, na obrazovanje, zagovara se ulaganje milijardi dolara za ostvarenje "ideologija umiranja” djece i odraslih. 
od cijelog spektra ostalih popratnih okolnosti i posljedica tog strahotnog čina. Važno je omogućiti postupak i ohrabriti dijete u kojem ono pristaje ubiti (vlastito) dijete. Naravno, ništa od ohrabrenja i "lakšeg pristupa sigurnom pobačaju" ako se ne stane na stranu posvemašnje liberalizacije zakonodavstva, kako sugeriraju Smjernice.

\section{Nadalje, iste promiču CSE kao obvezu:}

5.1.... naglašavajući ustrajanje na obveznosti CSE-a od osnovnih do srednjih škola, na temelju novih globalnih odobrenja i standarda. Zahtijevaju da CSEprogrami, za koje smo prethodno naveli da su osmišljeni s ciljem podučavanja djece o seksualnim radnjama i navodnim seksualnim pravima (kako ih određuje Planned Parenthood), uključe sve seksualne identitete.

Točka 5. je "kruna" djela i lika institucija koje iza svega ovoga stoje. Lik je, između ostalog, 'lažljivac' jer obvezu (tek nominalno) vezuje za osnovne i srednje škole. Što reći za naputke i poduke takve vrste namijenjene već petogodišnjacima (v. infra)?

Ključ svega jest šarolikost "konfuzije" učiniti obveznom i sveprisutnom. I to na svim razinama obrazovanja, s jasnim naglaskom, još uvijek, ali ne i zauvijek, na osnovnim i srednjim školama. O vrtićima i 'vrtićarcima' progovara se tek ovlaš, još se možda čini netaktičnim decidirano na njih upućivati. Za sve se imaju pobrinuti "globalna odobrenja i standardi", stoji u famoznoj toč. 5. Jedno je sigurno, "globalna odobrenja i standardi" neupitan su primjer upitnosti značenja ove sintagme. Ili, možda obrnuto? Cilj je biti i ostati dosljedan u širenju konfuzije; ona postaje imperativ.

Nadalje, ciljeve učenja, navedene u spomentim Smjernicama, možemo dodatno predstaviti i kroz nekoliko razina poduke, 'sukladno' životnoj dobi djeteta, i to:

\section{a) prva razina (u dobi od 5 do 8 godina djeteta):}

Lapidarno, u toj dobi djecu se upoznaje s masturbacijom, koja im se predstavlja kao nešto prirodno, nešto što nije štetno, a što im može biti ugodno (?!), (str. 43-48. Smjernica) te ih se upoznaje s izvorima informacija koje ljudi stječu o vlastitom spolu, rodu i spolnosti i to prvenstveno kroz kulturu i religiju (str. 39.). Nadalje, već zarana podučava ih se i kako “... svi ljudi, neovisno o njihovom zdravstvenom statusu, religiji, podrijetlu, rasi ili seksualnom opredjeljenju mogu podizati djecu i pružiti im ljubav koju zavređuju" (str. 51. Smjernica).

Zanimljivo bi bilo znati kojim didaktičkim sredstvima i pedagoškim metodama ovo približiti petogodišnjaku koji, sigurni smo, ni sam pojam predmeta poduke neće moći izgovoriti. Pita li se tko - je li dijete to uopće zanima, zašto ga zbunjivati nejasnim, za njegovih 5 godina nebitnim, a da ne upotrijebimo drugu riječ; u kojoj mjeri su roditelji s tim upoznati i ne samo upoznati, nego pita li ih se za mišljenje; djeci je "ugodan" i sladoled i bombon i igra s prijateljem i štošta drugo, zašto bi se dijete navodilo baš na ovu vrstu "ugode"? Kome je cilj da tako bude i tko se takvom vrstom 'prosvijećenosti' petogodišnjaka može okoristiti, jasno je kao dan.

Petogodišnjaka se "kroz kulturu i religiju" informira o vlastitom spolu, rodu i spolnosti. Nevjerojatno providno. Ovako upakiranim pristupom u omot "kulture i 
religije", bez potrebe za detaljiziranjem smisla i poslanja poduke, želi se, vjerujemo, otupiti oštricu roditeljskog protivljenja. S vremena na vrijeme, Smjernicama postaje važno i mišljenje roditelja, poglavito ako bi se ono moglo izraziti u vidu negodovanja. To je i najbitnije jer dijete, ionako, u toj dobi nitko u vrtiću ne pita što bi željelo učiti. A kako to postići do li zaodijevanjem (za dob djeteta, nedopustive i nepotrebne) tematike kulturološkim i religijskim osnovama koje pogađaju u srž životnih stavova, svjetonazora i vjerskih opredjeljenja djetetovih roditelja. Dakle, potrebno je, barem s vremena na vrijeme, utišati roditelje.

Zanimljivo je da se petogodišnje dijete podučava kako ama baš svi ljudi, pa čak i "neovisno o seksualnom opredjeljenju", mogu podizati djecu i "pružiti im svu ljubav koju zavređuju". S jedne je strane zahtjevno, ali, s druge, istovremeno je i podlo dijete podučavati i uvjeravati da netko može imati dvije majke ili dva oca i da mu isti mogu pružiti "svu ljubav koju zavređuje". Čak i onda ako mu se na vrlo prizeman način pokuša objasniti značenje 'seksualnog opredjeljenja roditelja'. Zahtjevno je utoliko što je u osnovi netočno jer dijete za ispravan odgoj, za odgoj cjelovite i zdrave osobnosti, neminovno treba majku i oca, svakog sa svojim značajno različitim ulogama u odgojnom procesu. Stoga, za potpuni razvoj i za nešto što mu se želi prikazati kao sva ljubav koju zavređuje, mora imati oca i majku, muški i ženski odgojni model u kojem je nemoguć, za ispravan rast i razvoj djeteta, nadomjestak nepostojećeg. Dakle, od svakog iole odgovornog i savjesnog odgajatelja, učitelja i sl. očekuje se da podučava u istini. Riječ je o bezvremenskoj istini koja nije evoluirala ni u kojem smjeru. Smatramo dostatnim pozvati se na stav neprikosnovenog autoriteta E. Fromma koji ističe: "Majka je dom odakle smo došli, ona je priroda, zemlja, ocean. Otac ne predstavlja takav dom, on ima slab dodir s djetetom, pogotovo u prvim godinama života, te se važnost oca u tom periodu ne može usporediti s važnošću majke. No, majčina i očeva stajališta prema djetetu odgovaraju djetetovim vlastitim potrebama. Djetetu su potrebna majčina bezuvjetna ljubav i briga, i psihološki i fiziološki. Djetetu su nakon šeste godine života znakovito potrebni i očeva ljubav, njegov autoritet i vodstvo. Majčina je uloga da usadi osjećaj sigurnosti, dok ga otac podučava i vodi kako bi se moglo suočiti s problemima koje mu zadaje društvo u kojem se rodilo". ${ }^{53}$ Fromm majčinu ljubav opisuje kao bezuvjetnu, ono ne treba ništa činiti da bi tu ljubav zadobilo, voljeno je samim tim što postoji. Majčina ljubav nikada ne prestaje, ali rastom i odrastanjem ona postaje, na određeni način, manje važnom, a očeva ljubav koja je drugačija i uvjetovana, od određene životne dobi (vidjeli smo, nakon šeste godine) postaje sve važnija. U bezuvjetnoj majčinoj i uvjetovanoj očevoj ljubavi nalazi se pozitivan i negativan aspekt. ${ }^{54}$ Fromm ne propušta navesti kako je obitelj majke i oca idealan model odgoja. Naime, ... "zrela osoba doseže točku razvoja na kojoj

53 Erich Fromm, Umijeće ljubavi, Naprijed, Zagreb, 1982., str. 43-44.

${ }^{54}$ Očinska ljubav može se, kako kaže Fromm, izboriti vlastitim ponašanjem (jer princip očeve ljubavi je: "volim te zato što ispunjavaš moja očekivanja, što vršiš svoje dužnosti, što si sličan meni ...", znači očeva ljubav mora se zaslužiti) ali može se i izgubiti, ako dijete ne čini ono što se od njega očekuje. Očinska ljubav nije izvan djetetove kontrole, kao što je slučaj s majčinskom ljubavlju. Djetetu je neophodna upravo ta bezuvjetna majčinska ljubav. Ibid., str. 43-44. 
predstavlja vlastitu majku i vlastitog oca. Zrela osoba se oslobodila vanjske majke i oca, ali ih je izgradila iznutra". ${ }^{55}$ Izostanak majčinskog, odnosno očinskog modela u odgoju i odrastanju djeteta moguće je stručnim promatranjem prepoznati kod odraslih osoba jer isti, prema Frommovim istraživanjima, generiraju neurozama.

S druge strane, ovakva edukacija koju nudi međunarodna zajednica, uključuje i podlost. Naime, ako se poduka bazira na zamračivanju istine o istospolnom roditeljstvu koje može pružiti "svu ljubav koju dijete zavređuje", to nije poduka već zločin u vidu svjesnog i namjernog zaglupljivanja narašaja i naraštaja djece te oduzimanja djetetu onoga što mu, po naravi stvari, pripada - oca i majke, muškarca i žene.

Potrebno se osvrnuti i na stavku ove točke prema kojoj se djecu podučava da sve osobe neovisno o njihovom zdravstvenom statusu mogu podizati djecu i pružiti im ljubav koju zavređuju. Uz dužno poštovanje spram osoba s invaliditetom i međunarodnih dokumenata koja zaštićuju prava takvih osoba,${ }^{56}$ ne možemo kazati da sve osobe neovisno o svom zdravstvenom statusu mogu udovoljiti ovoj potrebi djece. To naprosto nije točno, jer nije uvijek ni moguće, niti ostvarivo.

\section{b) druga razina (u dobi od 9 do 12 godina):}

Na ovoj 'višoj razini' djeca bi, prema Smjernicama, trebala već steći saznanja o detaljima seksualnog zadovoljstva. O tome tko ga kome i na koji način može pružiti (uz prilično detaljiziranje tijeka postupka), (str. 43-44. i str. 51.). Potom im se daje 'definicija' orgazma i opisuje se njegova uloga (str. 49.). Također, piscima Smjernica činilo se potrebnim dodatno ohrabriti djecu, u smislu da određena zabava može uroditi i 'plodom', o kojem autori Smjernica, istina, ništa bitnije ne kažu, osim da “... zakonom dopušten pobačaj koji se obavlja u sterilnim uvjetima od strane medicinski obučenog osoblja - jest siguran" (str. 51). Devetogodišnja bi djeca trebala, uza sve što bi im se serviralo kao najnormalnije i najprihvatljivije za svoju životnu dob, još samo zaviriti u knjige i propise kako bi znala što im je raditi za slučaj da se, uz svu "svoju zrelost i odgovornost", ipak nešto neplanirano dogodi. I tad će saznati da je sigurnost pobačaja, od strane društvene zajednice, "zajamčena" stručnošću kadra i sterilnošću uvjeta u kojima se isti obavlja.

\section{c) treća razina ( u dobi od 12 do 15 godina):}

Ova razina seksualne edukacije započinje nužnošću “... uvažavanja različitih seksualnih orijentacija i rodnih identiteta” (str. 48.); nadalje, time da “... i muškarci i žene mogu davati i primati seksualno zadovoljstvo s partnerom istog ili suprotnog spola" (str. 50). Također, poduka uključuje i pitanje odgovornosti (?!) svakog od partnera kako za osobno zadovoljstvo, tako i za zadovoljstvo partnera pri čemu se ukazuje na važnost učenja uzajamne partnerske komunikacije (str. 50). I na ovoj razini, uči se o pristupu sigurnom pobačaju i skrbi nakon pobačaja (str. 52).

55 Op. cit., str. 43-44.

56 Uzmimo, primjerice, Konvenciju o pravima osoba $s$ invaliditetom, Zakon o potvrđivanju Konvencije o pravima osoba s invaliditetom i Fakultativnog protokola uz Konvenciju o pravima osoba s invaliditetom, Narodne novine - Međunarodni ugovori, br. 6/2007. 
Smjernice ukazuju na pojam apstinencije samo kao na jedan od niza izbora dostupnih mladima $\mathrm{i}$ to na prilično neobičan ali ipak očekivan način, kroz posljedično opisivanje apstinencije "kao nečega što se temelji na strahu, kontroli seksualnog ponašanja mladih ljudi ulijevanjem straha, srama i osjećaja krivnje". ${ }^{57}$ A znamo da nedorasli žele biti odrasli, slobodni i hrabri. Dakle, apstinencija je tek jedna od mogućnosti koja se vjerojatno nije mogla zaobići i koja, očigledno, nije bila vrijedna nikakvih razrada (osim da se istu poveže sa strahom, sramom i krivnjom). Iako, rekosmo, većina mladih ljudi nerado želi ostaviti dojam zastrašenih, posramljenih, krivih. Ovakvo pojašnjenje apstinencije sasvim je shvatljivo s obzirom na intencije tvoraca Smjernica.

Sve prethodno navedeno na životu je već nekoliko godina. Početkom 2018. godine uslijedilo je revidirano izdanje Smjernica o seksualnom obrazovanju djece UNESCO-a kao posebne UN-ove agencije za obrazovanje. ${ }^{58}$ Smjernice iz 2009. godine služile su kao obrazovni resurs koji je bio globalno primjenjiv, lako prilagodljiv lokalnom kontekstu. Međutim, kako stoji u revidiranoj verziji Smjernica iz 2018., ovo područje se brzo razvijalo, što naravno nije slučajnost uz svu silu nastojanja pa je time nastala potreba ponuditi još suvremeniji razvojni okvir unutar ovog područja kako bi pozicija i relevantnost seksualne edukacije postala još razumljivija i prihvatljivija. Potrebu za dodatnim razmatranjem ove problematike ponajviše je potaknuo aklamacijski pristup te prihvaćanje rodne perspektive diljem svijeta (neki je ispravno prepoznaju ne samo kao "globalnu političku normu" 59 već i kao "kulturu koja postaje globalna" ${ }^{60}$ ), a sukladno tome i prihvaćanje medicinskih intervencija nad adolescentima.

Ponukan ozbiljnošću situacije, oglasio se FWI, kritizirajući UNESCO-ove Smjernice iz 2018. godine. Prema mišljenju FWI-a, ${ }^{61}$ navedene Smjernice:

\section{Iskrivljuju pojam apstinencije:}

a) "Treba shvatiti da apstinencija znači neodabiranje bilo kakvog vida seksualnih aktivnosti ili odlučivanja kada i s kime započeti s istima" (str. 71. Smjernica, Learning objectives 9-12 years).

Međunarodna zajednica svoj podmukao plan gradi na poluistini, točnije, na laži, obmani, neprihvatljivim modalitetima intrigacije, ali i na zastrašivanju, zaglupljivanju djece, odvlačenju pozornosti od svega što je na istinsku dobrobit djeteta, od svega primjerenog i dobrodošlog djetinjstvu, djetetovoj dobi i zrelosti.

57 StopCSE.org/EXCERPTS: UNESCO's International Guidelines on Sexuality Education, http:// www.comprehensivesexualityeducation.org/cse-programs-exposed-not-a-live-page/excerpts-unescosinternational-guidelines-on-sexuality-education/, (11. I. 2019.).

58 Riječ je o revidiranom izdanju International Technical Guidance on Sexuality Education, nastalom u suradnji UNESCO-a, UNAIDS Secretariata (Switzerland), UNFPA-e (The United Nations Population Fund), UNICEF-a, UNWomena i WHO-a, 2018. $62-81$.

59 Vidi: Marguerite A. Peeters, Rodna revolucija - Vodič za razlučivanje, Verbum, Split, 2016., str.

60 Ibid., str. 82-103.

61 Family Watch International (FWI) https://www.comprehensivesexualityeducation.org/curiculum/ unesco2018/, 17. I. 2019. 
Međunarodna zajednica, svjesna svojih uspješnica na planu razaranja braka i obitelji, sada još mora poraditi na djeci jer ona su ta koja polučenim ostvarenjima jamče budućnost, nikako povratak na ranije, na staro. Stoga, treba djecu zarana oblikovati onako kako bi instrumentalizirana postala kiborzi budućnosti, oni koji neće skretati sa zacrtane trase svojih programera.

b) "Apstinencija nije trajno stanje u životu mladih ljudi" (str. 18., 2.2., Other key considerations in the evolving field of CSE).

c) "Apstinencijski programi su se pokazali neučinkoviti i potencijalno štetni za spolno i reproduktivno zdravlje i prava" (str. 18.).

\section{Promiču seksualno zadovoljstvo za djecu:}

a) "Opisuju odgovore muške i ženske djece na spolnu stimulaciju" (str. 71., Learning objectives 9-12 years).

I ovo je sasvim očekivano, jer djeci od 9 godina, a i ranije, međunarodna zajednica smatra potrebnim ukazati na svu primamljivost 'dječjih radosti' za koje se ona, kao njihova dobrotvorka, pobrinula. Naravno, na tom putu smatra ključnim zaintrigirati ih, potaknuti im maštu, ohrabriti ih na seksualna eksperimentiranja jer samim tim već je pola posla obavljeno.

b) "Uključivanjem u seksualno ponašanje dijete bi se trebalo osjećati ugodno" (str. 72., Learning objectives 15-18 years).

Čak se, u svrhu poticanja i ohrabrivanja djece, istima nudi i nagrada za hrabrost u vidu zajamčene ugode.

c) Predlažu "sažeti ključne elemente seksualnog zadovoljstva i odgovornosti" (str. 72., Learning objectives 15-18 years). Naravno, uvažavajući učinke prethodne edukacije, djeca od 15-18 godina moći će se zadovoljiti i sažecima.

d) Ovo životno razdoblje djece podrazumijeva "... razmišljanje o tome kako rodne norme i stereotipi utječu na očekivanja i iskustvo seksualnog zadovoljstva" (str. 72., Learning objectives 15-18+ years).

Kad smo kod rodnih stereotipa, istaknuli bismo da su u nedavno objavljenoj studiji u časopisu Journal of Adolescent Health ${ }^{62}$ analizirani podaci iz različitih zemalja o tome kako djeca i adolescenti percipiraju svoje odrastanje kao dječaci ili djevojčice te je u njoj istaknuto kako "štetne rodne stereotipe djeca usvoje već do 10. godine života", ${ }^{63}$ što zapravo šalje poruku da s obvezom poučavanja o štetnosti rodnih stereotipa, tj. s rodnom pedagogijom pod egidom istinoljublja i zaloga za sretniju budućnost djece, treba započeti vrlo rano, svakako prije 10. godine života.

62 Robert W. Blum, Kristin Mmari, Caroline Moreau, „It Begins at 10: How Gender Expectations Shape Early Adolescence Around the World“, Journal of Adolescent Health, October 2017, Volume 61, Issue 4, Supplement, str. S3-S4. Usp.: Chunyan Yu, Xiayun Zuo, Robert W. Blum, Deborah L. Tolman, Anna Kågesten, Kristin Mmari, Sara De Meyer, Kristien Michielsen, Sharmistha Basu, Rajib Acharya, Qiguo Lian, Chaohua Lou, „Marching to a Different Drummer: A Cross-Cultural Comparison of Young Adolescents Who Challenge Gender Norms“, Jorunal of Adolescent Health, October 2017, Volume 61, Issue 4, Supplement, str. S48-S54.

63 Intervjuirana su djeca u dobi od 10 do 14 godina, u petnaest država na pet kontinenata. Istraživanje je pokazalo da su mlađi adolescenti već imali "rodni oklop". 
Dakle, što dodatno zbunjivanje i opterećivanje djece ovakvim stvarima počne ranije, tim bolje.

\section{Promiču seksualne aktivnosti u ranoj dobi i promiskuitet:}

a) "Mlade ljude treba što je moguće ranije i što je moguće opsežnije informirati o seksualnosti i spolnom zdravlju" (str. 35., 5.1. Goals, age groups and structure).

b) "CSE promiče pravo izbora kada i s kime će dijete imati bilo kakav oblik intimnosti ili spolni odnos..." (str. 18., Other key considerations).

Ovo je jedna od stavki CSE-a koja, čak i sama za sebe, govori sve. Uglavnom, važeći princip jest - neograničena sloboda za sve.

c) Nadalje, treba "prepoznati da je odluka svake osobe da bude seksualno aktivna osobna, da se može mijenjati tijekom vremena i istu treba poštovati u svakom trenutku" (str. 71., Learning objectives 12-15 years). Dakle, što dvanaestogodišnjak odluči, to treba poštovati. U pedoliberalnoj ideologiji CSE-a, za pojam roditelja/ zakonskog zastupnika, očigledno, nema mjesta.

d) Potrebno je "pokazati poštovanje spram različitih praksi koje se tiču seksualnosti" (str. 48., Learning objectives 9-12 years). Naravno, ovo djeci treba ugravirati u mentalni kod već od 9. godine kako u kasnijoj dobi ne bi bilo nepodopština i nedopustivih skretanja s trase CSE-a.

e) "Prepoznati da je informirano donošenje odluka o seksualnim aktivnostima (tj. biti dobro poučen i siguran u odlučivanju da li, kada i s kime postati seksualno aktivan), važno za djetetovo zdravlje i dobrobit" (str. 71., Learning objectives 12-15 years). U ovome razaznajemo tek pokušaj ublažavanja strahote navedene u toč. c), (v. supra), koja nikoga ne treba zavarati. Ne zaboravimo, odluka je osobna, dakle, u konačnici 'ostaje' na djetetu i mora je se poštovati, sviđala se ona nekome ili ne.

f) "Seksualni odnosi bez penetracije lišeni su rizika nenamjerne (neželjene) trudnoće, nude smanjeni rizik od STIS-a, ${ }^{64}$ a mogu biti ugodni" (str. 72., Learning objectives 12-15 years).

g) Potrebno je "podržati pravo za svakoga ... da izrazi svoja seksualna osjećanja" (str. 78, Learning objectives 12-15 years).

Jer, nije dovoljno podučiti, potrebno je i "podržati". I to ne bilo kako, već "na razini prava".

h) CSE može ... "pomoći djeci i mladim ljudima da stvore pristojne i zdrave odnose s ljubavnim ili seksualnim partnerima" (str. 17., 2.1. What is Comprehensive sexuality eduation /CSE/?).

Gotovo su suvišna pitanja tipa: Što to CSE podrazumijeva pod "pristojnim" i "zdravim"?

Također, ovo "ili" u sintagmi "s ljubavnim ili seksualnim partnerima" trebalo bi značiti da seksualno partnerstvo ne bi trebalo uvijek i nužno pretpostavljati i ljubavno partnerstvo, pa čak i onda kada se radi o djeci. Ne treba posebno ni

${ }^{64}$ STIS - Sexually Transmitted Infections (HIV/AIDS). 
isticati koja se sve, da tako kažemo, vrata pakla otvaraju prihvaćanjem stava - 'sve zamislivo postaje ostvarivo'. Čak, kada je i od CSE-a - koji sam sebe predstavlja kao "poučitelja, pomagača, poticatelja, podržavatelja, ukazatelja, prepoznavatelja, promicatelja dobrobiti djece" - za zdrav razum, previše je.

i) Treba "imati za cilj osposobiti djecu i mlade ljude za razvoj pristojnih društvenih i seksualnih odnosa" (str. 16., 2.1. What is CSE?).

Ovaj vid osposobljavanja djece 'kruna' je djelovanja ovakvih i sličnih organizacija, udruga i sl. Naravno, "pristojnost" se strateški najprije vezuje za društvene odnose, iako isti nisu ni cilj ni prioritet poslanja ovakvih institucija, već neizbježni pripadak, ukrasni detalj koji bi trebao ublažiti značaj onoga što slijedi seksualnih odnosa djece.

j) "Tijekom puberteta dječaci i djevojčice postaju više svjesni svojih 'odgovora' na seksualnu privlačnost i stimulaciju” (str. 71., Learning objectives 9-12 years).

\section{Promiču transrodnu ideologiju i uvažavanje različitosti rodnih identiteta:}

a) Nužno je objasniti “... kako nečiji rodni identitet možda neće odgovarati njegovom biološkom spolu” (str. 50., Learning objectives 9-12 years).

Zapravo, cilj je nužno skrenuti djetetu pozornost na nešto o čemu dijete uopće ne razmišlja već mu odrasli serviraju to gorko jelo 'mogućnosti oslobođenja od jarma biološke datosti' i eksperimentiranja s društvenim kreacijama roda. Opet stvaranje zbrke i konfuzije, forsiranje nečega čemu nema mjesta ili barem ne bi trebalo biti mjesta u djetinjoj dobi.

b) Treba uputiti na nužnost "iskazivanja uvažavanja za rodni identitet drugih osoba" (str. 50., Learning objectives 9-12 years).

c) Potrebno je "definirati rod i biološki spol i opisati razliku među njima" (str. 50., Learning objectives 5-8 years).

Svakako, znakovito je da je ova razina 'edukacije' namijenjena već najranijoj dobi djeteta, a sukladno uzrečici "zlo ne kasni".

d) Jednako tako potrebno je djecu naputiti na " ... razmišljanje o tome kako se osijećaju spram vlastitog biološkog spola i roda” (str. 50., Learning objectives 5-8 years).

Vidimo, i potreba napućivanja, razmišljanja i preispitivanja vlastite spolnosti namijenjena je najranijoj dobi. "Napućivanje djece na razmišljanje" je zanimljivo sročena formulacija u kojoj razaznajemo strahotu tiranijskog nastojanja na planu rane seksualizacije djece; CSE preuzima ulogu "GPS-a" u instrumentalizaciji i vođenju djece najkraćim putevima do cilja.

e) "CSE doprinosi rodnoj ravnopravnosti podizanjem svijesti o raznolikosti rodova u životu ljudi” (str. 17., 2.1. What is CSE?).

Upravo "podizanje svijesti”, i to kod najmlađih, je važna alatka za ostvarivanje željenih ciljeva. Te iste najmlađe se čak i koristi kao sredstvo u promotivne svrhe sve nakaradnosti takve ideologije. O tome najbolje govori činjenica da je National 
Geographic u siječanjskom izdanju 2017. godine $^{65}$ iskoristio devetogodišnjeg dječaka za promicanje rodne ideologije kao novog društvenog normativa.

f) Nužno je "definirati homofobiju i transfobiju" (str. 50., Learning objectives 15-18 years) te,

g) "Analizirati društvena pravila koja su doprinijela homofobiji i transfobiji i njihove posljedice" (str. 50., Learning objectives 15-18+ years), kao i

h) "Predstaviti načine iskazivanja podrške ljudima koji su iskusili homofobiju ili transfobiju" (str. 50., Learning objectives 15-18+ years).

5. Promiču afirmaciju raznolikih seksualnih orijentacija s naglaskom na tome kako bi “... svi ljudi trebali moći voljeti onoga koga oni žele" (str. 50., Learning objectives 15-18+ years).

Ovo je od naizgled objektivno prihvatljivog polazišta, postala svima znana mantra koja se koristi, kako to navodi i FWI, za legalizaciju istospolnih brakova.

U sklopu UN-a neizostavno je barem spomenuti nezanemarivu ulogu Svjetske zdravstvene organizacije (WHO) koja već duže vrijeme, a intenzivnije od 2013. godine razmatra i pitanje rodne inkongruencije u fazi djetinjstva à propos 11 . verzije Međunarodne klasifikacije bolesti. ${ }^{66} \mathrm{Na}$ Konferenciji "Gender, Inclusivity and Protecting the 21 st Century Family" ${ }^{67}$, održanoj početkom srpnja 2019. godine u Londonu, u organizaciji ICFLPP-a ${ }^{68}$, na kojoj se okupilo preko 250 stručnjaka iz različitih područja (od prava do kliničke i forenzične psihologije), razvidno je da je pitanje roda bilo središnja tema. Problematiziralo se, između ostalih, i pitanje dobi u kojoj djeca mogu tražiti priznanje promjene spola. Također, istaknuto je kao ohrabrujuće i to što je WHO odlučio ukloniti rodni identitet iz spomenute Međunarodne klasifikacije bolesti s popisa mentalnih poremećaja. ${ }^{69}$

\subsection{Vijeće Europe i Europska unija}

I Vijeće Europe (VE), kao međunarodni mastodont (sada već) nejasnih ingerencija, koje uz ures multilateralizma kao novog eufemizma za globalnu oligarhiju bez demokratskog legitimiteta sve češće djeluje mimo volje građana, ${ }^{70}$

65 Special Issue: Gender Revolution, National Geographic, January 2017.

66 Global Action for Trans Equality, Critique and Alternative Proposal to hte "Gender Incongruence of Childhood" Category in ICD-11, https://globaltransaction.files.wordpress.com/2012/03/critique-andalternative-proposal-to-the-_gender-incongruence-of-childhood_-category-in-icd-11.pdf (preuzeto 14 . VI. 2018.).

67 International Centre for Family Law, Policy and Practice 'Gender, Inclusivity and Protecting the 21 st Century Family’ London 2019, International Family Law Journal, 2019, Issue 3, str. 199-202.

68 ICFLPP - International Centre for Family Law, Policy and Practice.

69 Više o svemu što je tome prethodilo, vidi u: Dijana Jakovac-Lozić, ,, 'Rod' protiv 'spola' - polazište na putu razaranja braka i obitelji“", Zbornik radova Pravnog fakulteta u Mostaru, Petnaesto međunarodno savjetovanje Aktualnosti građanskog i trgovačkog zakonodavstva i pravne prakse, 2017., str. 8-10.

70 Nino Raspudić, Kamo to odlazi naša ministrica, http://www.večernji.hr/premium/kamo-to-odlazinaša-ministrica-1328656 (23. IX. 2019.). 
posljednjih godina daje svoj izdašan obol na ovom planu. Kao najsvježiji primjer može poslužiti nametanje ratifikacije Istanbulske konvencije u Hrvatskoj ${ }^{71}$ kao tobožnjeg lijeka za pomoć i zaštitu žrtvama obiteljskog nasilja, ${ }^{72}$ o kojoj je detaljnije bilo riječi u nekim ranijim radovima. ${ }^{73}$ Ovdje ćemo tek podsjetiti da je jedan od njenih ciljeva iskorjenjivanje svih "predrasuda, običaja i tradicija" koje se temelje na "stereotipnim ulogama žena i muškaraca" (čl. 12.), kao i nametanje koncepta roda u domeni obrazovanja, kroz školske kurikule, kao modaliteta preodgoja djece i mladih temeljenog na postavkama rodne ideologije. Konkretno, zahtijeva od država stranaka da uključe pitanje "roda" i "nestereotipnih rodnih uloga" u redovan nastavni plan i program i to na svim razinama obrazovanja (čl. 14. st. 1.). Ovakva ideologija protivna je, ponajprije, zdravom razumu, jer u sebi i po sebi, razara ljudsko biće, lišavajući ga temeljnog sadržaja komplementarnosti žene i muškarca i nedopustivo ju je dovesti u poziciju nametanja bilo kome. Ovakvo nametanje protivno je pravu roditelja da budu primarni odgojitelji svoje djece, da budu oni koji će odabrati vrstu odgoja za svoju djecu, protivno je i slobodi savjesti,

71 Council of Europe Convention on preventing and combating violence against women and domestic violence, CETS No. 210. Ista je otvorena za potpisivanje 11. V. 2011., a stupila je na snagu 2014. Potpisale su je 46 država, a od toga su je 34 države ratificirale. Od međunarodnih organizacija potpisala ju je Europska unija (13. 06. 2017.), https:/www.coe.int/en/web/conventions/full-list/-/conventions/ treaty/210/signatures?p_auth=cz27Cn63 (11. III. 2019.)

Vidi i: Zakon o potvrđivanju Konvencije Vijeća Europe o sprečavanju i borbi protiv nasilja nad ženama i nasilja u obitelji, Narodne novine - Međunarodni ugovori, br. 3/2018. i Objava o stupanju na snagu Konvencije Vijeća Europe o sprečavanju i borbi protiv nasilja nad ženama $i$ nasilja u obitelji, Narodne novine - Međunarodni ugovori, br. 4/2018.

72 Ovoj se Konvenciji i prema riječima stručnjaka za kazneno pravo Pravnog fakulteta u Zagrebu profesora Davora Derenčinovića, mogu uputiti brojni prigovori, od nomotehničkih do sadržajnih. Ističe se da je Konvencija bremenita brojnim slabostima. Sasvim je pogrešno pitanje uzroka nasilja u jednom društvu svesti na jedan zajednički nazivnik, primjerice na tzv. rodnu uvjetovanost. Teza o takvoj uvjetovanosti nasilja ne može se održati. Nasilje je multikauzalna pojava i postoji niz faktora koji ga uvjetuju - poput bioloških, antropoloških, socijalnih, socioloških, psiholoških. To znači da se ne može cjelokupni fenomen nasilja među bliskim osobama svesti na nazivnik tzv. rodne uvjetovanosti. Riječ je o simplifikaciji, nedovoljnom poznavanju etiologije koja se odnosi na uzroke nasilja u društvu, u: Ivan Tašev, „Što s dokumentom koji promiče rodnu ideologiju“, Glas Koncila, br. 28, 16. srpnja 2017., str. 9.

73 O Konvenciji više, u: Dijana Jakovac-Lozić, ,'Rod' protiv 'spola' - polazište na putu razaranja braka i obitelji“, Zbornik radova Pravnog fakulteta u Mostaru, Petnaesto međunarodno savjetovanje Aktualnosti građanskog $i$ trgovačkog zakonodavstva $i$ pravne prakse, 2017., i u: Dubravka Hrabar, Istanbulska konvencija i zamke rodne perspektive, Zagreb, 2018. 
a također i didaktičkoj autonomiji škola. ${ }^{74}$ Nadalje, ista predviđa ekstenziviranje rodne ideologije kako u "neformalnim obrazovnim okruženjima, tako i u sportskim te kulturnim okruženjima, okruženjima za slobodno vrijeme te u medijima" (čl. 14. st. 2. Konvencije).

U svakom slučaju, gender i LGBT-agende te strpljiv rad na posvemašnjoj seksualizaciji djece, što u Europi, kao i u ostatku svijeta, priželjkuju pedofilski lobiji, ${ }^{75}$ zamišljen su triptih međunarodne zajednice od kojeg ona neće odustati. Primjerice, u Strategiji Vijeća Europe za prava djece (2016-2021. $)^{76}$ koju je u ožujku 2016. usvojilo Vijeće ministara, jasno se navodi: "Konačno, borba protiv diskriminacije će, kroz medije i obrazovanje, obuhvatiti i diskriminaciju na temelju spola, promicanje jednakosti djevojčica i dječaka, borbu protiv stereotipa, seksizma i pretjerane seksualizacije djece". Pažljivijem čitatelju neće promaknuti da se ovdje pojavljuju pojmovi koji jedni druge isključuju ili, u najblažu ruku, ostaju nejasnima (što se, u ovakvim slučajevima, pokazuje poželjnim) npr. što u kontekstu borbe protiv seksizma i 'pretjerane' seksualizacije djece znači "pretjerano"? Tko je taj koji bi trebao procijeniti težinu spomenutog standarda? Nadalje, što podrazumijeva "borba protiv stereotipa", (III. t. 1. Strategije)? Je li borba protiv stereotipa tek puko sredstvo nametanja iščašenog pogleda na čovjeka, je li to pokušaj dekonstrukcije čovjeka, rastakanja demodé obitelji koja je, na sreću, za mnoge još uvijek 'mala ecclesia', sa svim posljedicama prihvaćanja nametnutog, tuđeg, prevrednovanje sebe samih jer se taj netko osjeća pozvanim uvjeriti nas da nismo ono što jesmo? Što ta borba podrazumijeva od svega ovoga? Vjerojatno, sve zajedno.

74 S obzirom na stvarnost s kojom se već suočavaju roditelji nekih stranih zemalja (primjerice, Kanade, pojedinih američkih saveznih država /npr. Ohio/ i dr.) koji se, ako ne podržavaju raznorodna opredjeljenja na planu seksualnosti, rodnih opredjeljenja, čak i ako ne pružaju dovoljnu podršku "transrodnosti” vlastitog djeteta i sl., izlažu riziku da im vlasti oduzmu djecu. Naprosto, za drugačije mišljenje, u eri verbalizirane i svake druge vrste skrnavljenja demokratičnosti i demokracije, u eri razmrvljenih ljudskih prava, neće biti mjesta drugačijem mišljenju, pa makar dolazilo i od roditelja. Naprosto, roditeljsko negiranje i neprihvaćanje takvih društvenih zadanosti, tretirat će se kao najgori vid zlostavljanja djeteta kojeg će od istog 'spašavati' vlasti. Kada spominjemo Kanadu, moramo reći da je u njenoj pokrajini Ontario, 1. lipnja 2017. godine usvojen Zakon kojim se relativizira značaj uloge roditelja u odgoju djeteta. Isti predviđa oštre sankcije spram roditelja koji nisu otvoreni prema odgojnim i obrazovnim metodama koje uključuju zagovaranje homoseksualnosti, rodne ideologije i sl. Ako isti, na bilo koji način, suprimiraju ili onemogućavaju dijete u slobodnom izražavanju njegove seksualnosti, njegovih opredjeljenja i sklonosti, smatrat će se da roditelji ne poštuju najbolji interes djeteta. Kako ovo nazvati do li najgorim mogućim oblikom totalitarizma? Vidi: Dave Bohon, Ontario Passes Law to Take Children From Parents Who Oppose "Gender Expression”, NewAmerican, 7 June 2017, https:/www.thenewamerican.com/culture/ family/item/26200-ontario-passes-law-to-take-children-from-parents-who-oppose-gender-expression (preuzeto 26. I. 2018.). Usp.: Bill 89, Supporting Children, Youth and Families Act, 2017, https://www. ola.org/en/legislative-business/bills/parliament-41/session-2/bill-89 (preuzeto 13. IX. 2019.).

75 Tko se sve može pronaći u ulozi, primjerice, UN-ovog konzultanta za dječja prava, govori i podatak da je upravo osoba na takvoj poziciji, dugi niz godina seksualno zlostavljala i sodomizirala dječaka. Riječ je o iznimno cijenjenom konzultantu Glavnog tajnika UN-a i pojedinih tijela UN-a koja su involvirana u pitanje prava djece. Na zahtjev UNICEF-a isti je bio i vodeći autor priručnika o provedbi Konvencije UN-a o pravima djeteta (1998.). V.: UNICEF Consultant Sexually Assaulted Boy for Years, https://c-fam. org/friday_fax/unicef-consultant-sexually-assaulted-boy-years/ (preuzeto 12. III. 2018.).

76 Council of Europe Strategy for the Rights of the Child-Children's human rights, March 2016, https://rm.coe.int/168066cff8 (preuzeto 4. XI. 2019.). 
Ovo je zanimljivo stoga što se upravo u domeni rodne ideologije često spominje pojam stereotipa. Ona sama boluje od unutarnjih kontradikcija. Ista apsolutizira individualnu slobodu, a zapravo je konformistička i hoće sve građane svrstati uz svoje redukcionističke klišeje. Pravi se da je holistička i da uzima u obzir kompleksnost stvarnosti, a zapravo se zatvara u stereotipe koji isključuju stvarnost. ${ }^{77} \mathrm{~A}$ onda protiv tih istih stereotipa najavljuje žestoku borbu. Ili, npr. kada se u Strategiji govori o "životu bez nasilja za svu djecu” (t. 3. Strategije), s pravom se pitamo treba li indoktrinaciju djece rodnom ideologijom, uopće seksualizaciju djece kroz razne 'odgoje' i sl. smatrati i nazvati pravim imenom - "nasiljem nad djecom"? ?78 Isto tako, zar izlaganje djeteta zajednici (su)života nekoliko osoba koje idu pod zajednički nazivnik roditelja, također, i transrodnih, transseksualnih, interseksualnih, homoseksualnih i svih inih roditelja nije svojevrsno nasilje nad djecom? Pri čemu se, dodatno, nitko od tih i takvih roditelja, društvene zajednice ili međunarodnih tijela kao ključnih dobrotvora dječjih prava ne pita kako se osjeća to dijete koje, zapravo, nitko ništa ne pita? Koliko se njemu sviđa biti dijelom takve roditeljske (obiteljske) zajednice? Zar ta sva sila odraslih koji se gorljivo brinu za vlastitu ugodu i ne pitaju se je li to isto tako ugodno i njihovoj djeci - nije ništa drugo do li svojevrsno nasilje nad djecom? U istoj toj toč. Strategije, govori se i o blagodatima Istanbulske konvencije čije je ključno poslanje sprečavanje i suzbijanje nasilja nad ženama i obiteljskog nasilja s ciljem zaštite djevojčica ... Pitamo se, zašto ne i dječaka? Tim više što se toč. 3. imenuje kao: Život bez nasilja za svu djecu. U točki 35. Strategije stoji: "Radi borbe protiv rodne diskriminacije i radi promicanja jednakosti djevojčica i dječaka, Vijeće Europe nastavit će rješavati pitanja stereotipa i seksizma, osobito u medijima i u odgojno-obrazovnom sustavu, ${ }^{79}$ te pitanja hiperseksualizacije. Ovo potonje je, s jezičnog aspekta, čisti oksimoron, a s aspekta recentnog trenutka, čista laž. Naime, međunarodna zajednica, pa tako i VE, najavljuju borbu protiv hiperseksualizacije djece, a zapravo, sve te i takve njihove aktivnosti idu pod zajednički nazivnik hiperseksualizacije. U svakom slučaju, sviđalo se nekome ili ne, činjenica je da je, primjerice, tzv. "rodno osjetljivo obrazovanje" postalo dijelom i hrvatske nacionalne politike. ${ }^{80}$ Uvedeno je i prije ratifikacije Istanbulske konvencije.

77 „Ako postoji stereotipizirana kultura u kojoj je diskurs odvojen od stvarnosti, u kojoj ljudi više ne razmišljaju svojom glavom, onda je to upravo ona u kojoj živimo - naime postmodernost!" Tako: Marguerite A. Peeters, Rodna revolucija - vodič za razlučivanje, Verbum, Split, 2016., str. 102-103.

78 Takvo stajalište je zauzelo, primjerice, i ranije spomenuto Američko udruženje pedijatara (ACP). Vidi: Pushing gender ideology on kids is child abuse: pediatricians group, https://www.lifesitenews.com/ news/gender-ideology-leads-to-child-abuse-pediatricians-group (preuzeto 13. IX. 2018.).

79 Vidi: CM/Rec (2007) 13 o rodnoj osviještenosti u odgojno-obrazovnom sustavu.

80 U dokumentu "Nacionalna politika za ravnopravnost spolova za razdoblje od 2011. do 2015. godine”, jasno stoji “... provodit će se upoznavanje nadležnih tijela i ustanova s Preporukom CM/Rec (2007) 13 Odbora ministara VE državama članicama o rodno osviještenoj politici obrazovanja. S tim u svezi, uvest će se rodno osjetljiv odgoj i obrazovanje u cjelokupni obrazovni sustav, uz uklanjanje rodnih stereotipa iz udžbenika i nastavnih planova i programa. Donijet će se novi Udžbenički standard kojim se podiže kvaliteta rodno osjetljivog obrazovanja, a etički i jezični standardi udžbenika kao i likovnografička rješenja usklađuju se s načelima ravnopravnosti spolova", https://narodne-novine.nn.hr/clanci/ sluzbeni/2011_07_88_1868.html (preuzeto 14. XII. 2018.). 
U točki 36. Strategije stoji: „Na temelju Preporuke CM/Rec(2010)5 o mjerama za suzbijanje diskriminacije na osnovi seksualne orijentacije ili rodnog identiteta, Vijeće Europe provest će istraživanje o položaju LGBT $i$ interseksualne djece u vezi s ostvarivanjem njihovih prava“.

Ovakvu formulaciju metaforički bismo nazvali čokoladnom glazurom posnog tijesta koje se jedino slatkim začinom doima jestivim. Upotreba i svrha floskula začinjenih željenom, usmjeravajućom (da ne kažemo, nametnutom) interpretacijom pojedinih odredaba, postaje jasna svakome tko želi da mu bude jasno. Ostaje pitanje tko je taj tko će procjenjivati i ocjenjivati tek kratkotrajnu, u pravilu, prolaznu fazu djetetovog odrastanja kada ono preispituje vlastita spolna nagnuća, tko je taj tko će iz toga izvoditi zaključke o djetetovoj homoseksualnosti, interseksualnosti, transrodnosti i sl.? Možda dijete, koje se, u načelu, ne pita za mnogo toga (za njegov život i odrastanje)? Ili roditelj, učitelj, država, tko? Hormonske terapije, da ne govorimo i kirurške promjene spola, ostavljaju vidljivog traga na djetetovom psihičkom i fizičkom životu, a povratka natrag nema. Tko je spreman na sebe preuzeti svu odgovornost čina poduzetih u jednoj prolaznoj životnoj fazi odrastanja, koja podrazumijeva (ne nužno) i propitkivanje spolne/rodne vlastitosti impuberuma?

U travnju 2015. godine Parlamentarna skupština Vijeća Europe usvojila je Rezoluciju 2048 (2015) o diskriminaciji prema transrodnim osobama u Europi. ${ }^{81}$ Respektirajući Preporuku CM/Rec(2010)5 (v. supra) i odredbe čl. 12. Konvencije o pravima djeteta UN-a, Parlamentarna skupština je pozvala države članice na uvažavanjei zaštitu prava transrodnih osoba, kako bi se omogućilo brzoi transparentno pravno priznanje spola na temelju samoodređenja. Rezolucija poziva na usvajanje jasnih, nedvosmislenih transinkluzivnih i antidiskriminacijskih propisa i mjera glede zlostavljanja i mržnje spram takvih osoba; hitno usvajanje transparentnih i dostupnih podataka pravnog priznanja roda, temeljenog na samoodređenju, bez ograničenja temeljenih na osobnim karakteristikama (poput životne dobi); obvezatno, u slučajevima koji se tiču djece, prioritetno razmatranje najboljeg interesa djeteta; razmatranje uključivanja opcije trećeg roda u identifikacijskim ispravama (za one koji ga traže); omogućavanje dostupnosti zdravstvene skrbi za transrodne osobe, te poduzimanje mjera kojima takve osobe (uključujući djecu) ne bi bile obilježene kao mentalno bolesne; proaktivnu uključenost glede pružanja informacija, podizanja svijesti i obučenosti (poglavito za stručne skupine).

Možemo spomenuti i Smjernice Odbora ministara VE o djetetu prijateljskoj zdravstvenoj skrbi (2011.). ${ }^{82}$ Iste stavljaju naglasak na pravo nediskriminacije, pravo uživanja najviših dostupnih zdravstvenih standarda, na izražavanje vlastitih stavova kojima bi se pridavao odgovarajući značaj sukladno dobi i zrelosti djetata.

81 PACE Resolution 2048 (2015), http://assembly.coe.int/nw/xml/XRef-DocDetails-en. asp?FileID=21736\&lang=en (preuzeto 20. XII. 2018.).

82 Guidelines of the Committee of Ministers of the Council of Europe on child-friendly health care (and their explanatory memorandum), Adopted by the Committee of Ministers on 21 September 2011, https://www.coe.int/t/dg3/health/Guidelines_o_child_friendly_health_care_English_version_.pdf (preuzeto 14. X. 2019.). 
Najbolji interes djece i tu se ističe kao prioritet. I u ovim Smjernicama svoje mjesto je iznašlo pitanje zdravstvene skrbi za transrodnu ili interseksualnu djecu.

Za ukazati je i na Rezoluciju 1952 (2013.) Parlamentarne skupštine VE o pravu djeteta na tjelesni integritet, ${ }^{83}$ na koji obvezuje i čl. 3. Konvencije o pravima djeteta. Ovdje se osobito stavlja fokus na sprečavanje svih povreda djetetovog tjelesnog integriteta koje bi mogle dugoročno utjecati na njegov život. Ističe se potreba za ustrajnim istraživanjima i stjecanju novih saznanja o posebnosti situacija u kojima se interseksualne osobe mogu naći; nitko se ne bi trebao podvrgavati medicinskim ili kirurškim postupcima koji nisu nužni; jamči se tjelesni integritet, autonomija i samoodređenje osoba kojih se to tiče, te se ukazuje na nužnost snabdijevanja obitelji interseksualne djece s primjerenim savjetovanjem i podrškom.

"Dječja prava ..." kažu autori Strategije, “... će se i dalje uključivati u sve relevantne nove konvencije i preporuke VE". Nastavi li se s ovakvim obrascima pristupu dječjim pravima, ne možemo ništa drugo zaključiti nego da djecu, pored ovakvih odraslih, čeka nezavidna budućnost.

Ne čini se suvišnim, s aspekta seksualizacije djece kroz raznolike školske odgoje, te realne (ne)mogućnosti roditelja da budu zaista primarni odgojitelji svoje djece, tek osvrt na doticaj s istom Europskog suda za ljudska prava (dalje: Sud) kojem je Europska konvencija za zaštitu ljudskih prava i temeljnih sloboda i pripadajući joj protokoli (dalje: EKLJP) ${ }^{84}$ temelj djelovanja. Pri tome od posebnog su značaja čl. 8. Konvencije ${ }^{85}$ koji se tiče prava na poštovanje privatnog i obiteljskog života, doma i dopisivanja; čl. 9. Konvencije ${ }^{86}$ koji se tiče prava na slobodu mišljenja, savjesti i vjeroispovijedi, te čl. 2. Prvog protokola uz Konvenciju ${ }^{87}$ koji se tiče prava na obrazovanje, te pripadajućeg mjesta i tretmana roditelja u ulozi odgojitelja i poučavatelja njihove djece.

83 Resolution 1952 (2013) of the Parliamentary Assembly of the Council of Europe on children's right to physical integrity, http://www.assembly.coe.int/nw/xml/XRef/Xref-XML2HTML-en.asp?fileid=20174 (preuzeto 14. X. 2019.).

84 Europska konvencija za zaštitu ljudskih prava i temeljnih sloboda (Convention for the Protection of Human Rights and Fundamental Freedoms - ETS 005, 1950) i Protokoli br. 1, 4, 6, 7, 11, 12, 13, 14, 15 uz Konvenciju, Narodne novine - Međunarodni ugovori, br. 18/1997., 6/1999., 8/1999., 14/2002., 13/2003., 9/2005., 1/2006., 2/2010., 13/2017.

85 Članak 8. glasi: “(St.1.) Svatko ima pravo na poštovanje svoga privatnog i obiteljskog život, doma i dopisivanja; (st. 2.) Javna vlast se neće miješati u ostvarivanje tog prava, osim u skladu sa zakonom i ako je u demokratskom društvu nužno radi interesa državne sigurnosti, javnog reda i mira, ili gospodarske dobrobiti zemlje, te radi sprečavanja nereda ili zločina, radi zaštite zdravlja ili morala ili radi zaštite prava i sloboda drugih."

86 Članak 9. Konvencije glasi: “(St.1.) Svatko ima pravona slobodu mišljenja, savjesti i vjeroispovijedi; to pravo uključuje slobodu da se promijeni vjeroispovijed ili uvjerenje $i$ slobodu da pojedinačno il $u$ zajednici s drugima, javno ili privatno, iskazuje svoju vjeroispovijed ili uvjerenje bogoslužjem, poučavanjem, praktičnim vršenjem i obredima. (St.2) Sloboda iskazivanja vjeroispovijedi ili uvjerenja podvrgnut će se samo takvim ograničenjima koja su propisana zakonom: koja su u demokratskom društvu nužna radi interesa javnog reda $i$ mira, zaštite javnog reda, zdravlja ili morala ili radi zaštite prava $i$ sloboda drugih."

87 Čl. 2. Prvog protokola uz Konvenciju glasi: "Nikome neće biti uskraćeno pravo na obrazovanje. U obavljanju svojih funkcija povezanih s odgojem i poučavanjem država će poštivati pravo roditelja da osiguraju odgoj i poučavanje u skladu sa svojim vjerskim i filozofskim uvjerenjima." 
Upravo “... odredbe čl. 2. Protokola br. 1 uz Konvenciju za zaštitu ljudskih prava ne dopuštaju državi da posredstvom obrazovnog sustava provodi indoktrinaciju djece, s tim da se zahtijeva da svaki oblik nastave i poduke koje dijete prima od države ostavi mjesta za usmjeravanje od strane roditelja ...". ${ }^{88}$

U predmetu Folger $\varnothing$ and Others v. Norway ${ }^{89}$ jasno se navodi to da je "... utvrđivanje i planiranje školskog kurikuluma, u načelu, dio koji pripada nadležnosti države, pri čemu je moguće uključiti informacije ili znanje vjerske ili filozofske naravi u kurikulum, pod uvjetom da se ono prenosi na objektivan, kritički i pluralistički način." 90

Drugim riječima, zabrana indoktrinacije koja bi se mogla smatrati nepoštovanjem uvjerenja roditelja jest granica koju država ne smije prijeći, u čemu Sud evidentno pronalazi dovoljnu zaštitu prava roditelja. Riječ je o sukobu interesa, kako navodi A. Radina (v. infra, bilj. 91), u kojem se na jednoj strani nalazi roditelj, na drugoj država te isto potkrepljuje podatkom kako je Sud odbacivao brojne zahtjeve u kojima su se roditelji (uglavnom) protivili integriranom i obveznom seksualnom obrazovanju u osnovnoj školi, te neuspješno pokušavali izuzeti svoju djecu iz nastave takvog sadržaja, upisujući ih u privatne škole ili ih obrazujući kod kuće. ${ }^{91}$

Nalazimo da je predmet A.R. $i$ L.R. protiv Švicarske ${ }^{92}$ jedan od novijih u nizu zahtjeva slične problematike koji se našao pred Sudom. Majka A. R. maloljetne L. R., rođene 2003. godine, državljanke Švicarske, podnijela je najprije, u kolovozu 2011., zahtjev osnovnoj školi u Baselu za izuzeće svoje sedmogodišnje kćeri s nastave seksualnog odgoja potkrijepljen navodom kako bi njezino sudjelovanje u takvoj nastavi bilo protivno temeljnim pravima zajamčenim Ustavom. No, isti odlukom upraviteljice škole nije bio prihvaćen. Podnositeljica zahtjeva se, potom, bezuspješno žalila Odsjeku za obrazovanje, te naposljetku i Upravnom sudu u Baselu. Nakon neuspješnih ishoda u postupku korištenja, prema mišljenju A. R., svih raspoloživih pravnih sredstava pred domaćim državnim tijelima, A. R. i L. R. podnose zahtjev Sudu, temeljeći ga na čl. 8. st. 1. EKLJP-a (pravu na poštovanje privatnog i obiteljskog života). Tada A. R. u istom navodi da ona nije protiv seksualnog obrazovanja u državnoj školi već samo dovodi u pitanje njegovu korisnost u vrtiću i prvim razredima osnovne škole, te u tome razaznaje povredu njenog prava iz spomenutog članka EKLJP-a, a također ističe da je i djevojčica izložena neopravdanom upletanju u njeno pravo na poštovanje privatnog života. Dodatno, u zahtjevu je istaknula i kršenje njezina prava na slobodu savjesti i vjeroispovijedi (čl. 9. st. 1. EKLJP-a), kao i kršenje zabrane diskriminacije (čl. 14. Konvencije), zajedno s prethodno navedenim člancima EKLJP-a.

\footnotetext{
88 Ana Radina, Pravo djeteta na slobodu vjeroispovijedi (doktorski rad), Zagreb, 2018., str. 158.

89 Folgerф and Others v. Norway (GC), (Application no. 15472/02, Judgment of 29 June, 2007), t. 84.

90 Ibid., t. 84.

91 Ana Radina, op. cit., str. 158.

92 A.R. and L.R. v. Switzerland, (Application no. 22338/15, Judgment of 19 December 2017).
} 
Sud može proglasiti nedopuštenim svaki pojedinačni zahtjev podnesen na temelju čl. 34. EKLJP-a a ${ }^{93}$ ako, između ostalog, "zahtjev smatra ... očito neosnovanim", ${ }^{44}$ a o čemu je riječ u navedenom slučaju, u odnosu na djevojčicu L. R. koja zapravo nije pohađala nastavu seksualnog obrazovanja prije završetka drugog razreda osnovne škole.

Glede čl. 8. st. 1. EKLJP-a Sud je ponajprije istaknuo da je jedan od osnovnih ciljeva seksualnog obrazovanja preveniranje seksualnog nasilja i iskorištavanja, što predstavlja stvarnu prijetnju fizičkom i psihičkom zdravlju djece te protiv istog djeca moraju biti zaštićena u svakoj životnoj dobi. Također, naglasio je da je jedan od državnih ciljeva pripremiti djecu za društvenu zbilju i samim time je opravdano seksualno obrazovanje vrlo male djece, pa i one koja pohađaju vrtić ili osnovnu školu. Zaključio je da švicarske vlasti nisu prekoračile 'manevarski prostor', tj. slobodu procjene, neizostavno ostavljenu domaćim vlastima. Glede prigora o povredi čl. 9. EKLJP-a, Sud je zauzeo stav da gospođa A. R. nije pružila dovoljno dokaza koji govore o povredi spomenutog članka, a glede povrede čl. 14. na koju gospođa A. R. ukazuje, Sud je mišljenja da ista nije iscrpila sva raspoloživa pravna sredstva jer se nije žalila na diskriminaciju pred Saveznim sudom (Federal Court).

Dakle, i ovaj predmet je, na određeni način, slijedio sudbinu svojih prethodnika $\mathrm{s}$ istom ili sličnom problematikom. ${ }^{95}$

Poželjnim se čini barem osvrt i na Europsku socijalnu povelju (ESC) koja je od 2003. godine na snazi i u Hrvatskoj. ${ }^{96}$ Riječ je o važnom sporazumu o ljudskim pravima, te u svezi s tim za ukazati je i na zanimljivost istupa Europskog odbora za socijalna prava (ECSR), ${ }^{97}$ kada je riječ o ovoj problematici.

Sukladno praksi ECSR-a, spolni odgoj i obrazovanje o reproduktivnom zdravlju moraju biti dio školskog kurikula. Naime, 2007. godine razmatran je predmet pokrenut od Interightsa ${ }^{98}$ protiv Hrvatske pred ECSR-om. U predmetu se navodi da je Hrvatska prekršila odredbe Europske socijalne povelje zbog

93 "Sud može primati zahtjeve bilo koje fizičke osobe, nevladine organizacije, ili skupine pojedinaca koji tvrde da su žrtve povrede prava priznatih u ovoj Konvenciji ili dodatnim protokolima što ih je počinila jedna visoka ugovorna stranka. Visoke ugovorne stranke obvezuju se da ni na koji način neće sprečavati djelotvorno vršenje toga prava".

94 Čl. 35. st. 3. (a) EKLJP-a.

95 Jiménez. Alonso and Jiménez. Merino v. Spain (zahtjev br. 51188/99, odluka od 25. V. 2000.), Dojan and Others v. Germany (zahtjev br. 319/08, 2455/08, 7908/10, 8152/10 i 8155/10, odluka od 13 . IX. 2011.). Vidi: A. Radina, ibid., str. 158.

96 European Social Charter (ESC), Complete list of the Council of Europe's treaties, no. 035 (October 18, 1961); ESC (revised), no. 163, (May 3, 1996), https://www.coe.int/en/web/conventions/fulllist (preuzeto 24. XI. 2019.). Vidi: Objava o stupanju na snagu Europske socijalne povelje i Dodatnog protokola Europskoj socijalnoj povelji (kojim se uspostavlja sustav kolektivnih žalbi), Narodne novine - Međunarodni ugovori, br. 8/2003.

97 European Committee of Social Rights (ECSR). Odbor nadzire provedbu Europske socijalne povelje, a čine ga nezavisni stručnjaci koji donose odluke o usklađenosti nacionalnog zakonodavstva i prakse Europske socijalne povelje putem postupka kolektivnih žalbi ili postupka nacionalnog izvještavanja. Vidi: Handbook on European law relating to the rights of the child, European Union Agency for Fundamental Rights and Council of Europe, 2015., p. 31.

98 International Centre for the Legal Protection of Human Rights (INTERIGHTS), https://www. interights.org 
nepružanja sveobuhvatnog i adekvatnog obrazovanja djeci i mladeži o seksualnom i reproduktivnom zdravlju. U zahtjevu Interightsa stoji da je “... hrvatski kurikulum takav da su žene primarno oslikane kao majke koje su odgovorne za podizanje djece" i da su "heteroseksualni odnosi prikazani kao "normalan' oblik odnosa". Prigovoreno je, također, da "izborni predmet katoličkog vjeronauka govori o seksualnosti isključivo u kontekstu braka i prokreacije, isključujući točne i objektivne informacije o upotrebi kondoma, kontracepciji i pobačaju, te opisujući homoseksualnost kao 'grešan' oblik seksualnosti." 99 Što reći, osim da zahtjev počiva na površnim i neargumentiranim prosudbama, a k tome nemoguće je oteti se i dojmu zadivljujuće budnosti nevladinih organizacija kada je u pitanju seksualizacija djece i sve što s njom i oko nje ide zajedno; kamo sreće da je ista razina budnosti i britkosti prisutna u istinskim problemima koji 'vape u nebo' za rješenjem.

Ukratko, prema ECSR-u, države moraju osigurati nediskriminatoran program spolnog odgoja i obrazovanja o reproduktivnom zdravlju "kojim se ne promiče, a niti podržava socijalna isključenost i uskraćivanje ljudskog dostojanstva. Nastavni materijali ne smiju promicati ponižavajuće stereotipe, primjerice one koji se odnose na osobe koje nisu heteroseksualne". ${ }^{100}$ Očigledno, sva nastojanja međunarodne zajednice teže istom cilju.

Kada je riječ o Europskoj uniji (EU), odredbama čl. 14. st. 1. i čl. 21. Povelje EU o temeljnim pravima ${ }^{101}$ jamči se svakome pravo na obrazovanje. Stavkom 3. članka 14. propisana je sloboda osnivanja obrazovnih ustanova, uz poštovanje demokratskih načela te prava roditelja da svojoj djeci osiguraju obrazovanje i poučavanje u skladu sa svojim vjerskim, filozofskim i pedagoškim uvjerenjima koja se poštuju u skladu s nacionalnim zakonima koji uređuju ostvarivanje takve slobode i prava. Uživanje prava na obrazovanje mora biti dostupno svima na jednakoj osnovi.

Glede homofobnog i transfobnog nasilja u školama, Europski parlament poziva na promicanje jednakosti i nediskriminacije i na području seksualne orijentacije i rodnog identiteta kroz programe Unije za mlade i obrazovne programe. ${ }^{102}$

Nadalje, odredbom čl. 24. st. 1. Povelje EU o temeljnim pravima djeci su zajamčena prava na zaštitu i brigu koja je potrebna za njihovu dobrobit, dok se st. 2. određuje da u svakom djelovanju koje se odnosi na djecu, bez obzira provode li

99 International Centre for the Legal Protection of Human Rights (INTERIGHTS) v. Croatia (predmet br. 45/2007.; 30. III. 2009.), https://adfininternational.org/legal/interights-v-croatia/, (preuzeto 24. XI. 2019.).

100 Handbook on European law relating to the rights of the child, European Union Agency for Fundamental Rights and Council of Europe, 2015., p. 137.

101 Povelja Europske unije o temeljnim pravima, Službeni list Europske unije, C 202/389, 7. lipnja 2016., https://eur-lex.europa.eu/legal-content/HR/TXT/PDF/?uri=CELEX:12016P/TXT (preuzeto 13. X. 2019.).

102 European Parliament Resolution of 4th February 2014 on the EU Roadmap against homophobia and discrimination on grounds of sexual orientation and gender identity, http://www.europarl.europa.eu/ sides/getDoc.do?type=TA\&language=EN\&reference=P7-TA-2014-0062 (preuzeto 23. I. 2018.). 
ga tijela javne vlasti ili privatne institucije, primarni cilj mora biti - zaštita interesa djeteta. $^{103}$

Međutim, kako smo, barem iz hrvatske političke, pravne i životne stvarnosti uvidjeli, moguć je dubok (a nevidljivi) jaz i ponor između, na jednoj strani, roditeljskih uvjerenja, htijenja i, na drugoj strani, sukladnosti istih s nacionalnim propisima koji počinju poprimati obličja isfabriciranih kreatura opterećenih nametnutim međunarodnim standardima. Istovremeno, o dječjim pravima, dobrobiti, interesima, govori se više nego ikada. Svakome, iole dobronamjernom i odgovornom, od količine zloporabe i manipulacije ovim riječima u javnom prostoru postaje loše. Nažalost, tako to počinje izgledati kada oni kojima je povjerena "volja naroda" svojim glavinjanjem bespućima politikanstva, putem pogube "volju", zaboravivši "narod".

Unatoč tome, što su, primjerice, Rezolucijom Europskog parlamenta o spolnom i reproduktivnom zdravlju i pravima, ${ }^{104}$ usvojenom 2013. godine, postavljena stanovita ograničenja glede spolnog i reproduktivnog zdravlja i prava, jasnim navođenjem da je “... oblikovanje i provedba politika povezanih sa spolnim i reproduktivnim zdravljem i pravima te spolnim odgojem u školama u nadležnosti država članica", ${ }^{105}$ uvijek se nađu pojedinci koji kroz svoje djelovanje unutar Unije smetnu s uma ovakve "sitnice" pa čak i nakon Estrela reporta. ${ }^{106}$

Krajem 2014. godine Europski parlament donosi Rezoluciju o 25. obljetnici Konvencije UN-a o pravima djeteta, u kojoj se, navodi: “... prava djeteta se i dalje krše ... između ostalog i u državama članicama Europske unije (EU), što je rezultat nasilja, zlostavljanja, iskorištavanja, siromaštva ... i diskriminacije zbog vjere, invaliditeta, spola, spolnog identiteta, dobi, etničke pripadnosti (toč. F) i dalje" ... budući da je sveobuhvatno obrazovanje o spolnosti sastavan i važan dio jačanja prava dječaka i djevojčica na dobrobit i zdravlje, kojim se promiče jednakost i bori protiv stereotipa (toč. J). Neovisno o 'snazi' jednog ovakvog dokumenta, znakovitim se svakako čini to što se u opticaj (nažalost, ne prvi put) stavlja varijabla spolnog identiteta djeteta i to kao osnova diskriminacije. Spol i spolni identitet nisu sinonimi. Identitet neke osobe određuje njezina slobodno izabrana spolna orijentacija, zato je on fleksibilan, promjenjiv, mnogostruk. Tu je i neizostavno računanje na ulogu i značaj sveobuhvatnog obrazovanja o spolnosti. Koliko god da

103 Više o pravima djece u Europskoj uniji, te o Povelji o temeljnim pravim Europske unije i obiteljskom pravu, u radovima autorica Dubravke Hrabar i Aleksandre Korać Graovac, u knjizi: Nada Bodiroga-Vukobrat, Nenad Hlača, Dubravka Hrabar, Dijana Jakovac-Lozić, Aleksandra Korać-Graovac, Davorin Lapaš, Irena Majstorović, Ines Medić Musa, Barbara Novak, Hrvoje Sikirić, Vanja Smokvina, Sandra Winkler, Viktorija Žnidaršič Skubic, Mirela Župan: Europsko obiteljsko pravo, Narodne novine, Zagreb, 2013., str. 25-71.

104 European Parliament resolution of 10 December 2013 on Sexual and Reproductive Health and Rights (2013/2040 (INI)), https://www.europa.eu/sides//getDoc.do?type=TA\&reference=P7-TA-20130548\&language $=\mathrm{EN} \&$ ring $=\mathrm{A} 7-2013-0426$ (preuzeto 12. X. 2018.).

105 Toč. A.1. Rezolucije.

106 Edite Estrela Report on Sexual and Reproductive Health and Rights (2013/2040(INI), 3. December 2013, https://www.europarl.europa.eu/sides/getDoc.do?type=REPORT\&reference=A7-20130426\&language $=\mathrm{EN}$ (preuzeto 12. X. 2018.). 
jest i taj segment edukacije bitan u odrastanju i obrazovanju djece, već smo poučeni iskustvom da se on u svojoj sveobuhvatnosti i te kako zlorabi. I, pitamo se, zašto je važno jačanje prava dječaka i djevojčica, a ne djece? (Prisjetimo se, primjerice, "Izvješća o osnaživanju djevojčica obrazovanjem u EU" /Rodrigues report ${ }^{107}$ / te Rezolucije Europskog parlamenta o osnaživanju djevojčica obrazovanjem u EU-u (2015.). ${ }^{108}$ Istim se propisivao sadržaj kurikula državama članicama EU-a ističući da u spolni odgoj svakako treba uvrstiti rodnu perspektivu. Prisjetimo se i nastojanja

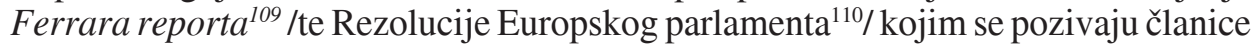
Unije, posredstvom Europske komisije, da priznaju pravo na pristup sigurnim i suvremenim kontraceptivima i spolnom odgoju u školama).

S obzirom na to da se prethodno spomenuta Rezolucija o 25. obljetnici Konvencije UN-a o pravima djeteta vezuje za Konvenciju o pravim djeteta, moramo zamijetiti da ista nije imala potrebu govoriti o pravima dječaka i djevojčica, već o pravima djece. Međutim, naravno, i za potrebe ovog dokumenta, kao neizbježno pokrivalo, poslužio je stereotip o čijem je značenju i svrsi već ponešto rečeno.

Sadašnjim očima viđenu, postojeću Europu, točnije, europsku civilizaciju, čini se, uskoro će trebati spašavati od nje same, poglavito kad je riječ o djeci.

Istinski oponenti recentnoj međunarodnoj politici, u ovom segmentu njenog djelovanja, izuzetna su rijetkost.

Takva nastojanja vrlo brzo iznalaze mjesta u nacionalnim europskim pravnim sustavima. Nadležna obrazovna tijela donose smjernice koje progovaraju o načinima "podrške" transrodne djece. Najnovije su, primjerice, Smjernice za podršku transrodnih učenika upućene školama u Sjevernoj Irskoj. ${ }^{111}$ Iste se kreću od pitanja školskih uniformi, oslovljavanja djeteta do korištenja sanitarnih prostorija, svlačionica i sl. i odraz su, kako ovlaštena obrazovna tijela Sjeverne Irske ističu, najbolje prakse $u$ pružanju potpore transrodnim učenicima. Iste se primjenjuju na predškolsku djecu, školsku djecu pa i onu viših uzrasta. Education Authority for Northern Ireland (EA) sačinio je te Smjernice koje transrodne osobe definiraju kao one koji "imaju rodni identitet koji se razlikuje od njihovog (dodijeljenog) im rođenjem - spolnog identiteta". Unatoč nepostojanju pouzdanih statističkih podataka o broju transrodnih osoba u Sjevernoj Irskoj, EA upućuje na rezultate istraživanja

107 Report on empowering girls through education in the EU, (2014/2250 (INI), A8-0206/2015, http://www.europarl.europa.eu/doceo/document/A-8-2015-0206_EN.html (preuzeto 14. XI. 2019.).

108 European Parliament resolution of 9 September 2015 on empowering girls through education in the EU, (2014/2250(INI), P8_TA(2015)0312, http://www. europarl.europa.eu/doceo/document/TA-82015-0132_EN.html (preuzeto 14. XI. 2019.).

109 Report on the situation offundamental rights in the European Union (2013-2014) (2014/2254(INI)), A8-0230/2015, http://www.europarl.europa.eu/doceo/document/A-8-2015-0230_EN.html (preuzeto 14. XI. 2019.).

110 European Parliament resolution of 8 September 2015 on the situation of fundamental rights in the European Union (2014/2254(INI)), P8_TA(2015)0286, http://www.europarl.europa.eu/doceo/document/ TA-8-2015-0286_EN.html (preuzeto 14. XI. 2019.).

111 “Northern Ireladn schools get guidance on support for transgender pupils”, https://www. belfasttelegraph.co.uk/news/northern-ireland/northern-ireland-schools-get-guidance-on-support-fortransgender-pupils-38604285.html, (preuzeto 21. X. 2019.). 
o rodnom identitetu u kojima se navodi da se između 0,17 i 1,3 posto adolescenata i mladih prepoznaju kao transrodni. U smjernicama EA-e ističe se kako je "važno da se mlade osobe osjećaju 'podržano' i da se 'promiču njihovi najbolji interesi'". Jasno, podrška i promidžba čine čuda po ovom pitanju. Međutim, nedopustivim se čini tako nešto stavljati uz bok 'najboljeg interesa djeteta'. Radi se, kako smo vidjeli, o vrlo niskim postocima, ali isti uznemiravaju državne strukture vlasti koje su brižne kada se radi o ovakvim, od njih samih, djeci nametnutim pitanjima. Međutim, te iste vlasti ne pokazuju ni približnu razinu brižnosti za ogromne postotke djece u istinskoj potrebi.

Djelovanje u maniri poslušničkog, kolonijalnog mentaliteta, udivljenja prema svemu onome što pristiže iz vanjskih centara moći, te sklonosti makijavelističkom plutanju niz struju, što nužno pretpostavlja odsustvo moralnog zakona u sebi, te osjećaja isključive odgovornosti prema nadređenim centrima moći jest ono s čime se i hrvatski narod, nažalost, suočava. Oćutjesmo to, između ostalog, i bljeskom u vidu 4. modula kurikula Zdravstvenog odgoja u školama, ohrabrenog novostečenim spoznajama iz djela Standardi spolnog odgoja u Europi. ${ }^{112}$ Kolika se dobrohotnost iza njega skrivala, a znanstvena utemeljenost postojala, otkrivaju hvalevrijedni napisi i reakcije brojnih hrvatskih liječnika, ${ }^{113}$ pravnika, psihologa, pedagoga. Svojedobno, po tom pitanju, reagiralo je i Znanstveno vijeće za obrazovanje i školstvo Hrvatske akademije znanosti i umjetnosti ${ }^{114}$ otvoreno se suprotstavivši uvođenju rodne idologije u obrazovne sadržaje u Hrvatskoj, proglasivši ih neprihvatljivima.

O sličnom se onomad, primjerice, očitovao i znanstvenik, genetičar T. Domazet Lošo u jednom izlaganju, ${ }^{115}$ kazavši: "Ogroman je pritisak na seksualizaciju djece kroz 4. modul i njemu slične stvari. Takva nastojanja su pogubna i zapravo pokušavaju odvrtiti evolucijski proces u obrnutom smjeru". Objasnio je to riječima: “... čovjek ima djetinjstvo i to na način da je njegovo spolno sazrijevanje evolucijski odgođeno te, u odnosu na čimpanzu, nastupa pet godina kasnije. Upravo tih pet godina djetinjstva ili adolescencije je onaj trenutak kada čovjek u smislu razvoja mozga ima vremena spojiti svoje neurone na najrazličitije načine. Evolucija osigurava da čovjek ima prostor kada može zadobiti intelektualne sposobnosti, maštu, te neke druge kognitivne sposobnost koje ga čine čovjekom u psihofizičkom smislu i to na način da se odgodilo njegovo spolno sazrijevanje. Ako forsirate i gurate djecu u neki oblik psihološkog preranog seksualnog sazrijevanja vi zapravo radite kontra evolucije, to znači da pokušavate kotač evolucije vratiti u obrnutom smjeru. To u biološkom smislu neće moći uspjeti zato što procesi koji nastaju na razini milijun godina su puno jači od nekakvih društvenih odluka. Čovjeku je darovano djetinjstvo

112 Standardi spolnog odgoja u Europi-okvir za kreatore političkih odluka, obrazovne i zdravstvene institucije i stručnjake, Savezni centar za zdravstveno obrazovanje, Regionalni ured Svjetske zdravstvene organizacije za Europu i Savezni centar za zdravstveno obrazovanje, BzgA, Köln, 2010.

113 Samo s Medicinskog fakulteta u Splitu, ni manje ni više nego šezdeset profesora potpisalo je peticiju u kojoj jasno iznose svoj stav glede spolnog odgoja kroz koji se provlači rana seksualizacija djece.

114 HAZU: Rodna ideologija u Istanbulskoj konvenciji neprihvatljiva za odgojno-obrazovni sustav, https://hu-benedikt.hr/?p=103436 (preuzeto 26. I. 2018.).

115 Tomislav Domazet Lošo, Biologijska evolucija - izazov za vjeru?!, izlaganje održano u organizaciji Požeške biskupije 28. veljače 2013. 
i spolno nesazrijevanje da bi bio nešto više u biološkom smislu. To je ono što nas čini ljudima".

Upotrijebivši eho ili ječna pitanja, ista bi glasila: U Europi i svijetu dogodilo se - što? Europa i svijet izgledaju - kako?

Primjerice, D. Murray ${ }^{116}$ Europu u ovom trenutku prepoznaje kao suicidalnu tvorevinu, koju takvom ponajprije čine brojni njezini vođe, ali je posve drugo pitanje jesu li ih i u kojoj su ih mjeri europski narodi odabrali u tome slijediti. Pri tome smatra da je civilizacija koju poznajemo kao Europu, u procesu počinjenja samoubojstva te da niti jedna zemlja ne može izbjeći tu sudbinu jer kao da bolujemo svi od istih simptoma i boljki. M. Schooyans ${ }^{117}$ Europu, pak, vidi kao "prevarenu i na to ponosnu". Uz rijetke izuzetke, glavnina europskih naroda kao da se nalazi u stanju neshvatljive hibernacije u vremenu konstantnih događanja i prihvaćanja silnica pristiglih iz UN-a. Imamo razloga vjerovati da buđenje Europe neće biti bezbolno. Riječ je o opasnostima koje prijete njenom moralnom, političkom, kulturnom i vjerskom identitetu. "Europa je postala prva žrtva i prva sudionica svjetskog hegemonistističkog projekta čiji žalac više nije vojna, pa čak ni gospodarska moć, nego pozitivno pravo. U ovom trenutku Europska unija je preslabo oboružana da bi mogla raskrinkati novo shvaćanje prava kako je spravljeno u SAD-u i kako se prenosi putem UN-a. Jer takozvana nova ljudska prava i još više novo shvaćanje prava i ljudskih prava što ih UN želi nametnuti svojim nacijama i svim ljudima, poziva se na sjevernoamerički model. U tome modelu, suci - pod pritiskom feminističkih i homoseksualnih lobija ili agresivnih protukršćanskih masonskih loža - ne oklijevaju izmisliti takozvana individualna, potpuno usitnjena nova prava koja nemaju nikakve veze ni s osobom, ni s čovjekom kao bićem koje je u odnosu s drugima ... Zbog UN-a, kao i zbog ortaštva njegovih najbogatijih i najutjecajnijih članica, to mahnito shvaćanje prava širi svoje krakove na svjetskoj razini ... Ta takozvana nova ljudska prava su istinsko remek-djelo ideološke prijevare. Takvo shvaćanje prava koje proizvodi bogata oligarhija na kraju će snažno doprinijeti slabljenju SAD-a ${ }^{118}$ i Europe, ali će prije toga posaditi ono što se zove 'bijela kuga', i posvuda po svijetu posijati smrt". ${ }^{19}$

116 Douglas Murray, Čudna smrt Europe - Imigracija, identitet, islam, Puls, Egmont d.o.o., Zagreb, 2018., str. 7-15. Riječ je o knjizi poznatog kolumnista Spectatora i Standpointa koji često piše za tiskovine. Slovi kao uspješan govornik; vodio je rasprave u britanskom i europskom parlamentu te u američkoj Bijeloj kući. Inače, knjiga je proglašena "političkom knjigom godine".

117 Michel Schooyans, Skriveno lice UN-a-Prema novoj svjetskoj vladi, Verbum, Split, 2006., str. $105-113$

118 Kad je riječ o Americi, korisno je uputiti na zanimljivu knjigu Davida Kupeliana “The Snapping of the American Mind - Healing a Nation Broken by a Lawless Government and Godless Culture" (Chapter 9: Gender Madness), WND Books, Washington, 2015. Autor, inače dugogodišnji novinar i jedan od 'najprodavanijih autora', prelijepu Ameriku sada vidi kao bizarnu Ameriku. Između ostalog, ukazuje na divlje slavljenje seksualne anarhije, njene zastrašujuće 'kulture', političke korektnosti i njenog nerazumijevanja temeljnih svetosti ljudskog života, što također, namjerno ili ne, predstavlja promicanje ovisnosti, razvrata, sloma obitelji, kriminala, korupcije, očaja, samoubojstava. U američkom društvu raste kaos. Američke najveće vrijednosti izokreću se naopako - do točke slavljenja ludila i demoniziranja normalnog.

119 Michel Schooyans, op. cit., str. 107-108. 
Sve to je već jasno prepoznatljivo i sasvim očekivano u takvoj globalnoj percepciji svijeta kao mase bez povijesti i kulture. Dovoljno je, barem na trenutak, posvijestiti instantna iščeznuća istine po kojoj "Europa počiva na kršćanskim zasadama" iz ključnih dokumenata Europske unije. Od kontroverznog Lisabonskog sporazuma kršćanskim temeljima Europe više nema spomena.

\section{BITI DIJETE “ISTOSPOLNIH RODITELJA” ILI “TRANSRODNOG” RODITELJA - JEDAN OD NAJOZBILJNIJIH I NAJIZRA VNIJIH NAČINA RANE SEKSUALIZACIJE DJECE}

Namijeniti djetetu suživot u obitelji istospolnih ili transrodnih roditelja jest ništa drugo nego nametanje mu životne situacije koja, htjeli mi to priznati ili ne, supsumira neminovno i pitanje rane seksualizacije. Dijete se uvodi u tu domenu već samom okolnošću pripadanja jednom, najblaže rečeno, nenaravnom roditeljskom okruženju. O njoj ne možemo, dakle, govoriti samo onda kada se događa na izvanjskoj relaciji: dijete - škola (vrtić), dijete - okruženje, ona očigledno, danas već, može biti i temelj oikosa. Pri tome ne pitajući dijete za želje, htijenja, očekivanja, kao ni za posljedice odrastanja u takvoj obitelji. Dakle, problem rane seksualizacije djece ne vreba uvijek i nužno izvana, on može biti i dijelom obiteljskog gnijezda, iako je, naravno, primarno određen kategorijama i parametrima 'izvanjskog'. Točnije, izvanjskim utjecajima i kreativnim modalitetima koji se mogu pronaći u ponudi međunarodne zajednice. U svakom slučaju, nije od iskona, nije naravno.

S. Freud je bio mišljenja “... svaka rana seksualizacija djeteta štetna je za njegov odgoj”. ${ }^{120}$ Dijete u ovakvim obiteljima jest naprosto dionik specifične, drugačije, nesvakidašnje seksualne stvarnosti svojih roditelja, participira u takvom zajedništvu i emocionalno i psihološki i na razne druge načine. Prinuđeno je razmišljati drugačije od većine svojih vršnjaka i prijatelja. Nitko ga ne pita ni koliko voli to 'drugačije' koje mu je namijenjeno niti kakve to može imati reperkusije za njegov daljnji život.

Naime, ono što je nekada predstavljalo obiteljsku stvarnost, bitno se promijenilo od pedesetih godina naovamo. Brak i dalje može biti kamen temeljac za obitelj i obiteljsko pravo, ali se više ne može tvrditi da je to i jedina priznata forma obiteljskog života i jedina obiteljska forma koja generira djecu. Obiteljsko pravo kreće se od usredotočenosti na brak prema usredotočenosti na dijete. Društvene promjene dovele su pod znatan pritisak postojeće strukture obiteljskog prava. ${ }^{121}$

120 Sigmund Freud, Gesammelte Werke, Fünfter Band (Werke aus den Jahren 1904-1905), Die Freudsche Psychoanalytische Methode, Drei Abhandlungen zur Sexualtheorie, Imago Publishing, London, Frankfurt am Main, Hamburg, 1942., str. 136.

121 Vjerujemo da je autor J. M. Scherpe pod "društvenim promjenama”, u navedenom kontekstu, mislio i na njihove produkte $u$ vidu istospolnog roditeljstva, transrodnog roditeljstva, korištenja usluga medicinski pomognute oplodnje, surogatstva i sl. Vidi: Jens M. Scherpe, „Breaking the existing paradigms of Parent-Children Relationships“, in: Gillian Douglas, Mervyn Murch, Victoria Stephens (eds.), International and National Perspectives on Child and Family Law, Intersentia, Cambridge - Antwerp Portland, 2018., str. 344-345. 
U ovakvom tijeku događanja, prepoznatljiva je, bilo kao počelo ili pak kao posljedica društvenih promjena, potreba za 'višom razinom usredotočenosti' upravo na dijete.

Međutim, u svim tim promjenama nastalim impulsom odraslih i njihovih ezoteričnih htijenja, razaznati rješenje, pače i dobrobit za dijete kao potencijalnog dionika takve obitelji i takvog roditeljstva postaje zahtjevno i slojevito. Poznato je koje i kakvo roditeljstvo odgovara najboljem interesu djeteta. O značaju jasne izdiferenciranosti roditeljskih (muško-ženskih) uloga u podizanju i odgoju djeteta, ranije je već bilo riječi (v. supra, 2.1.). Poznato je i ono što ranije nije spomenuto, a to je činjenica koliko roditelj koji pokušava u roditeljskoj ulozi oponašati ulogu roditelja drugog spola, može ostaviti negativnog traga u djetetovom odrastanju i razvoju. Da i ne govorimo o sadašnjem trenutku i svim kombinatorikama roditeljstva kojima suvremena obiteljskopravna stvarnost vrvi. Znanost je o tome davno rekla svoje i to su sudovi nepodložni utjecajima društvenih mijena i instantpolitike. Znamo što je djetetu potrebno za normalan rast i razvoj - jasna slika roditeljskih uloga (oca i majke), dvaju autoriteta koji se, upravo osnovom svojih različitosti, nadopunjuju na način koji je za dijete jedino dobar i prihvatljiv. Sve ostalo je rezultat političke i tobožnje korektnosti, koja ne oklijeva izmišljati nekakva individualna, potpuno usitnjena, "razmrvljena nova prava" ${ }^{122}$ koja nemaju, kako već ranije rekosmo, nikakve veze s čovjekom kao bićem koje je u odnosu s drugima.

Bilo kako bilo, paradigma „dijete ima jednog oca i jednu majku“ u mnogim zakonodavstvima, naprosto, više ne vrijedi. Priznavanjem istospolnih zajednica (bilo kao braka ili nekog oblika registriranog partnerstva) ne samo da se priznaju takvi "horizontalni odnosi", već se priznaje, također, i učinak takvih zajednica na njihov "vertikalni odnos" tj. odnos između roditelja i djece. Sve više zakonodavstava dopušta posvojenje istospolnim parovima i povećanjem broja takvih partnerstava, dopušta se i pristup medicinski pomognutoj oplodnji te surogatstvo. Takvi partneri postaju roditeljima. Mnoga djeca odrastaju unutar istospolnog partnerstva, bilo da ona dolaze iz nekog prethodnog odnosa partnera ili su posvojena od strane pojedinca koji je živio u istospolnom partnerstvu ili su 'rezultat' medicinski pomognute oplodnje. Mnogo slučajeva, zabilježenih i kroz sudsku praksu, bili su upravo oni u kojima se muški ili ženski par odlučio imati dijete zajedno (bilo da je jedan od muškaraca donirao sjeme, a jedna od žena nosila dijete) ili se ženski par obratio, primjerice, prijatelju za doniranje sjemena. Barem na početku, namjera je često bila, za sve njih, da djeluju kao roditelji djeteta - iako bi zakon dopustio dvoma od njih da budu zakonski roditelji (tako je bilo u većini pravnih sustava, ali danas postoji i tzv. višestruko roditeljstvo). ${ }^{123}$ U brojnim slučajevima to je znalo dovesti do oštrih sukoba kada bi se odnosi između odraslih narušili ili bi se pojavile određene nesuglasice. Budući da zakonski propisi nisu mogli priznati roditeljsku uključenost

122 M. Schooyans, ibid., str. 107.

123 Vidi potpoglavlje 4.4. Multiple Parenthood, u radu: Jens M. Scherpe, „Breaking the existing paradigms of Parent-Children Relationships“, in: Gillian Douglas, Mervyn Murch, Victoria Stephens (eds.), International and National Perspectives on Child and Family Law, Intersentia, Cambridge Antwerp - Portland, 2018., str. 353-356. 
svih 'roditelja', ishodi su često bili (i još uvijek su) vrlo nezadovoljavajući i štetni za dijete. U svakom slučaju, danas se dijete doista može roditi i nemati 'zakonsku majku' (legal mother) i 'zakonskog oca' (legal father) jer može imati dva roditelja 's istim zakonskim rodom' (with the same legal gender). Štoviše, u sve većem broju zakonodavstava sada je moguća promjena spola bez podvrgavanja fizičkoj promjeni tijela. ${ }^{124}$ Stoga, osobe koje su pravno 'muškarci' mogu roditi dijete, a osobe koje su 'pravno' žene, mogu postati 'otac' djeteta. Također, mali ali rastući broj pravnih sustava sada omogućava osobama da ne budu pravno registrirane bilo kao muškarci ili kao žene. ${ }^{125}$ To ozbiljno dovodi u pitanje tradicionalne pojmove 'majke' i 'oca' i može biti još jedan razlog da se ukine spomenute pravne kategorije i jednostavno ih se zamijeni s kategorijom 'roditelj' (kao što je slučaj, primjerice, s Maltom kada je legalizirala istospolni brak /Marriage Act and other Laws - Amendment, 2017/ ili kanadskom pokrajinom Ontario prilikom 'osuvremenjivanja' Zakona o roditeljstvu 2016. godine). ${ }^{126}$ Uz prethodno rečeno, čini se da raste konsenzus o demedikalizaciji i depatologizaciji spolne tranzicije i 'sve veća svijest' da nužnost fizičke promjene tijela i/ili sterilizacija predstavljaju ozbiljno kršenje ljudskih prava. Naime, u presudi A. P., Garçon and Nicot v. France (2017.) ${ }^{127}$ Europski je sud za ljudska prava zauzeo stav da uvjet obvezne sterilizacije ili drugih prisilnih tretmana transrodnih osoba u svrhu pravnog priznavanja roda, predstavlja kršenje čl. 8. Europske konvencije za zaštitu ljudskih prava i temeljnih sloboda. ${ }^{128}$

Očigledno idemo za time da, u potrebi udovoljavanja željama odraslih, koje nerijetko dotiču granicu patološkog, iste na "dnevnoj bazi” servilno darujemo željom pretočenom u pravo, dok za to vrijeme (a i poslije) dobrobit djece ostaje nevidljiva. Pitamo se, prateći događanja na ovom području, gdje su ostale savjest i odgovornost odraslih spram djece? Možemo li zamisliti kako je djeci, koja ne mogu utjecati na to, živjeti s dvoje roditelja koji nisu otac i majka, onakav otac i onakva majka kakvi su djetetu nužno potrebni za ispravno odrastanje i život? Zašto mu svjesno i namjerno uskraćujemo ono što ga po svim zakonima prirode pripada? I da se ne pitamo dalje, jer očigledno, ljubitelje razmrvljenih ljudskih prava ovakva tradicionalna, primitivna, priglupa pitanja mogu uznemiriti. A oni imaju pravo na svoj mir, pravo na toleranciju 'netolerantnih', pravo na nediskriminaciju, svu silu drugih prava i što je najbitnije, "pravo" na 'svoje' dijete, kako oni to najčešće zamišljaju.

124 Više u: Jens M. Scherpe, ibid., str. 346-347.

125 Primjerice, u Njemačkoj, Indiji i Nepalu. Više u: Jens M. Scherpe, Anatol Dutta, Tobias Helms (eds.), The Legal Status of Intersex Persons, Intersentia, Cambridge - Antwerp - Chicago, 2018., str. 1-22 $\mathrm{i} \mathrm{dr}$.

126 J. M. Scherpe, op.cit., (4.3. Multiple Parentage), str. 352-353.

127 Case of A.P., Garçon and Nicot v. France, (Applications nos. 79885/12, 52471/13 and 52596/13, Judgment of 6 April 2017.

128 J. M. Scherpe, „Breaking the existing paradigms of Parent-Children Relationships“, in: Gillian Douglas, Mervyn Murch, Victoria Stephens (eds.), International and National Perspectives on Child and Family Law, Intersentia, Cambridge - Antwerp - Portland, 2018., str. 347. 
Sva ta sila istospolno usmjerenih, transrodnih, ${ }^{129}$ interseksualnih ${ }^{130}$ i sl., trebaju dijete. A potonjima, već na samom početku, mogućnosti su brojne, mogu birati čak između sedamdesetjednog (71) rodnog identiteta. ${ }^{131}$ Gdje se u svem tom metežu pogubila dobrobit djeteta? U vremenu slobode ludosti i stida zdravoumnosti, kada osobe koje su pravno priznate muškarcima mogu roditi dijete, kao što i osobe koje su pravno žene mogu postati očevima djece (u manjem, ali rastućem broju zakonodavstava to se omogućava i osobama koje nisu pravno registrirane ni kao muškarci, niti kao žene), je li moguće ne govoriti ne samo o konfuziji roditeljskog odnosa u eri tzv. pluriroditeljstva, te posljedicama koje ona podrazumijeva za ispravno odrastanje djeteta, već i o nedopustivosti i svoj štetnosti takvog odnosa za dijete ${ }^{132}$ koje bi trebalo biti u središtu svake zajednice, čija bi dobrobit trebala biti imperativ, pravo nad svim pravima? Xavier Lacroix, filozof i profesor etike na Institutu za obiteljske znanosti i na Teološkom fakultetu u Lyonu, lijepo kaže: "Čim se hoće promišljati roditeljstvo - ili "parentalnost" - van svake tjelesne usidrenosti ili, u najmanju ruku, van svakog podupiranja razlike, ostajemo pri plutanju među predodžbama i umišljajima. Izrazi 'očinstvo' i 'majčinstvo' ne daju se prekivati po volji. Oni upućuju na utjelovljenje. Tijelo je ipak nešto više od biološkog. Ono je mjesto iskonskoga darivanja života, onkraj prokreacije. Očinstvo i majčinstvo su tjelesni po tome što oni zahvaćaju sveukupnu osobu". ${ }^{133}$ To su nužni uvjeti koji će djeci pružiti najviše izgleda da razmašu sve dimenzije svojega čovještva, kako to vidi i Lacroix. Ako govorimo o nečemu drugačijem, moramo razmišljati jesu li djeca dovoljno otporna da se prilagode željama, htijenjima i maštarijama odraslih, te kakav će trag 'prilagodba' ostaviti na njih kao odrasle osobe. Za početak, misaona, emocionalna i psihološka zbunjenost djeteta očekivana je reakcija.

S ciljem prilagodbe svim recentnim oblicima obitelji, roditeljski bi se položaj trebao promatrati kroz tri razine, koje je predložio i dalje razvijao Andrew Bainham ${ }^{134}$

129 O pojmu transrodne / transseksualne osobe, vidi: D. Jakovac-Lozić, ,'Rod' protiv 'spola' polazište na putu razaranja braka i obitelji“, str. 136 i dalje.

130 Interseksualna osoba jest osoba rođena sa spolnim karakteristikama (kao što su kromosomi, genitalije i/ili hormonalna struktura) koje ne pripadaju strogo muškoj ili ženskoj vrsti ili koje pripadaju objema istovremeno. Liječnici često savjetuju roditeljima izvođenje kirurške ili druge medicinske intervencije na interseksualnom novorođenom djetetu kako bi se njegovo tijelo naizgled podudaralo $\mathrm{s}$ muškim ili ženskim obilježjima. Često, takve intervencije nisu medicinski nužne i mogu imati krajnje negativne posljedice na interseksualnu djecu kako ona budu odrastala. Tako: Jens M. Scherpe, u: Jens M. Scherpe, Anatol Dutta i Tobias Helms (eds.), The Legal Status of Intersex Persons, Intersentia, Cambridge - Antwerp - Chicago, 2018., str. 3. Usporedi u istom izvoru i Darlington Statement: Joint Consensus Statement from the Intersex Community Retreat in Darlington, March 2017, str. 11.

131 Vickie Pasterski, u: Jens M. Scherpe, Anatol Dutta i Tobias Helms (eds.), The Legal Status of Intersex Persons, Intersentia, Cambridge - Antwerp - Chicago, 2018., str. 65.

132 Upravo o 'opravdanosti' smisla izraza "homoroditeljstvo", o argumentima biseksualnosti, pluriroditeljstva, o rascjepkanoj filijaciji i brojnim drugim opterećenjima kojima generiraju razni novokomponirani oblici roditeljstva, lijepo progovara Xavier Lacroix, u svom djelu "Konfuzija rodova homoseksualnost, brak, posvajanje", Svijetla točka, Zagreb, 2014., str. 17-56. str. 24

133 X. Lacroix, Konfuzija rodova - homoseksualnost, brak, posvajanje, Svijetla točka, Zagreb, 2014.,

134 Jens M. Scherpe, „Breaking the existing paradigms of Parent-Children Relationships“, in: Gillian Douglas, Mervyn Murch, Victoria Stephens (eds.), International and National Perspectives on Child and Family Law, Intersentia, Cambridge - Antwerp- Portland, 2018., str. 350-358. 
(1. podrijetlo, 2. roditeljstvo i 3. roditeljska odgovornost). Međutim, u brojnim pravnim sustavima zamjetni su problemi, naime, ono što se predlaže podijeliti na tri razine neraskidivo je povezano ograničenim razumijevanjem pojmova: roditelja, podrijetla i paradigme 'dvaju roditelja'. Možemo samo pretpostaviti kolikoj količini zbunjenosti i nerazumijevanja izlažemo male dječje glavice, a sve zbog bezobzirnosti i neodgovornosti odraslih koji svoju seksualnost, neka svoja opredjeljenja i htijenja stavljaju u prvi plan, ne odričući se ujedno i želje za roditeljstvom na bilo koji način i pod bilo koju cijenu pa makar se ona dala izraziti u nesreći vlastite im djece. Koga će dijete zvati ocem, koga majkom? Zapravo, mogućnosti multipliciranja roditeljstva i roditeljske odgovornosti ozbiljno prijete rješenju kojem se već neke države priklanjaju, a to je jednostavno ukidanje takvog nazivlja i zamjene istog pojmom 'roditelj'. Međutim, terminološke preinake neće otkloniti probleme i pitanja s kojima se dijete, kod suvremenih oblika roditeljstva, prisiljeno suočiti.

Sukladno podukama kojima su današnja djeca izložena te njihova utjecaja na viđenje svijeta i prilika koje ih okružuju, a time na određeni način i formiraju, zanimljivim se činio barem osvrt na onu djecu čije je djetinjstvo obilježilo upravo iskustvo odrastanja u obitelji koja je počivala na "istospolnom" ili "transrodnom / interseksualnom roditeljstvu". Mišljenja smo da takva djeca najvjerodostojnije progovaraju o tom pitanju. Jedna od njih je i Denise Shick koja je, možemo reći, svoj život posvetila važnosti pružanja novih spoznaja o svim posljedicama koje takvi, kako ih ona na nekim mjestima naziva, "ovisnici" nanose svojim obiteljima. D. Shick o tome govori ne samo kao netko čiji je život u djetinjstvu bio obilježen negativnim utjecajem vlastitog oca koji je sebe vidio i doživljavao kao ženu, već i kao netko tko je danas svakodnevno, kroz svoj rad, uključen u pružanje pomoći obiteljima suočenima s problemom transrodnosti. Njen osobni život i rad iznjedrio je i nekoliko objavljenih knjiga na ovu temu. ${ }^{135} \mathrm{Na}$ jednom mjestu kratko i jasno kaže: "Djeca transrodnih osoba će se neminovno boriti sa spoznajom da je njihova majka također i njihov otac ili obrnuto. To ih ranjava. Ja to znam jer sam ja, također, bila to dijete". ${ }^{136}$ Ono što je nekada zvučalo smiješno, čak i nemoguće, danas je i te kako moguće i nije više smiješno. Nekada davno, postavljala su se brojna pitanja glede znanstvenih mogućnosti i razmatrala njihova ostvarenja s obzirom na ljestvicu etičkih zadanosti i etičkih implikacija glede istih. Danas to više nije tako.

Godine 2002. liječnici su izveli operaciju spola na Tracy L., fizički su preoblikovali mladu damu u gospodina, Thomasa B. koji je odlučio zadržati svoje ženske reproduktivne organe. Šst godina kasnije, gospodin Thomas B. je zatrudnio i rodio kćer. Poslije je rodio još dva puta i dobio sinove. Godine 2012. Thomas B. se, zbog fizičkog zlostavljanja, razvodi od svoje supruge, međutim, uskoro sklapa novi brak i to s učiteljicom svoje djece. Teško je i za pretpostaviti što se zbivalo s djecom

135 Posebno bismo istaknuli sljedeće knjige: Denise Shick and Jerry Gramckow, My Daddy's Secret, Help4Families Press, Ashland, 2008.; Denise Shick and Help 4 Families, When Hope Seems Lost, Help4Families Press, Ashland, 2015.; D. Shick, Understanding Gender Confusion, Help4Families Press, Ashland, 2014.

136 D. Shick, Having Transgender Parent Will Hurt Kids Like It Hurt Me, http://thefederalist. com/2016/10/11/transgender-mans-child-hurt-will-hurt-kids/, 27. XI. 2018. 
Thomasa B. u svem tom metežu odnosa koji su generirali brojnim pitanjima. Bilo je za očekivati da je samo ta obitelj mogla znati odgovor na ovo pitanje. "Kako sam odrastala s transrodnim ocem", piše D. Shick, "ja sam to mogla vrlo dobro zamisliti. Temeljeno na različitosti, ja sam trpjela i patila gledajući svoju braću i sestre, te sam slutila da djeci Thomasa B. nije napravljeno ništa dobroga. Slutila sam da su ona zasigurno zbunjena, žalosna, ogorčena i ponekad strašno uplašena. Ta djeca će patiti i boriti se sa spoznajom da je njihova majka ujedno i njihov otac, ili obrnuto. Ako je već terminologija, sama za sebe, zbunjujuća za odrasle, zamislivo je kako, dan po dan, život izgleda za tu djecu."137

Prije sredine 20. stoljeća djecu su, uglavnom, podizala dva roditelja, otac i majka. Glavnina ljudi to je prepoznavala kao dobro organizirano uređenje društvene zajednice. Razvodi brakova bili su relativno rijetki, a jednoroditeljska obitelj je, u pravilu, podrazumijevala okolnost smrti jednog od roditelja, odsutnosti ( $\mathrm{u}$ pravilu) oca ili je bila posljedica razvoda braka. Razvod je ponekad nužnost i iako autorica naglašava da ne osuđuje razvedene ljude, ne propušta istaknuti da život u jednoroditeljskoj obitelji, iako može biti dobro i pozitivno okruženje, nikada nije i najbolje okruženje za djecu. U tu svrhu, autorica se poziva i na proglas bivšeg američkog predsjednika Obame 2008. godine, dok je još bio senator: "Znamo statistike - da je za djecu koja odrastaju bez oca pet puta veća vjerojatnost da će živjeti u siromaštvu i počiniti zločin, devet puta veća vjerojatnost da će odustati od školovanja i dvadeset puta veća vjerojatnost da će završiti u zatvoru. Kod njih je veća vjerojatnost da će imati problema u ponašanju, bježati od kuće ili postati roditelji kao tinejdžeri. I to utječe na slabljenje temelja naše zajednice". ${ }^{138}$

Izgleda da je moderno društvo našlo lijek i rješenje za društvo bez očeva. Čini se dostatnim imati jednu odraslu osobu koja je, biološki, i jedno i drugo, i otac i majka. Međutim, jedna osoba ne može ispuniti obje uloge ni fizički, ni emocionalno niti psihološki. Muškarac i žena daju, svatko od njih na svoj način, jedinstveni, nemodelirajući i neoponašajući udio i prilog (u) roditeljstvu. Djeca trebaju dva roditelja - oca i majku. Djeca se mogu prilagoditi i jednoroditeljskom domaćinstvu; mnoga su to učinila vrlo dobro. Ali, zašto, ako nije nužno, zašto ne omogućiti djeci najbolju roditeljsku situaciju? U scenariju roditeljstva "dva u jedan" ispunjene su želje odraslih osoba, ali pod koju cijenu za djecu? Gdje je tu prepoznatljiv najbolji interes djeteta? Svrha je obitelji odgojiti i othraniti djecu, a ne ispunjavati roditeljske želje. Promatrajući problem s aspekta transrodnosti, kada je jedan roditelj i otac i majka, djeca ne mogu ostvariti najbolji scenarij za realizaciju svih njihovih potreba. Nažalost, današnja kultura, afirmirajući pravo na izbor(e) odraslih, daje im sve veći prioritet ne samo u ostvarivanju zahtjeva već i u poticanju odraslih na takve zahtjeve, žrtvujući pri tome dobrobit djece. ${ }^{139}$

Heteroseksualnom roditeljstvu i heteroseksualnoj reprodukciji često se pristupalo, a mnogi i danas pristupaju, kao normalnoj i prirodnoj pri čemu se ova

137 Ibid.

138 Ibid.

139 Ibid. 
dva deskriptora shvaćaju i prihvaćaju kao uzajamni, ekvilibrirani osnaživači u određenju samog pojma roditeljstva.

U svezi s tim, pojedini znanstvenici ${ }^{140}$ ukazuju na to da se, unatoč njihovoj očiglednoj sličnosti, značenja pojmova "normalno i prirodno" bitno razlikuju - riječ je o razlici koja naliježe na pitanje položaja lezbijskog majčinstva i homoseksualnog očinstva kao inferiornog. Analize etičkih prosudbi o različitim načinima zasnivanja obitelji lezbijskih, homoseksualnih i biseksualnih ljudi, pokazuju da putevi prema roditeljstvu čine da se obitelj 'više normalno' oslanja na načine reprodukcije koji izgledaju zapravo 'manje prirodni'. Suvremene reproduktivne mogućnosti stvaraju obitelji koje sve više odstupaju od kulturne norme nuklearne obitelji. ${ }^{141}$ Kao rezultat takvih tenzija, različiti načini roditeljstva mogu se opravdati kao da su i u "najboljem interesu djece". Međutim, iako se ovo opravdanje usmjereno na djecu može fleksibilno primijeniti, ono također ima proturječno značenje. Niti visoko rangirani standard dobrobiti djeteta nije nužno pomogao uklanjanju određenih mogućnosti stvaranja obitelji kao zajednice manje usmjerene na djecu. Naprotiv, muškarci i žene okretali su se u različitim smjerovima, ovisno o tome kako su točno shvaćali i prihvaćali standard dobrobiti djece i time ga relativizirali, odnosno prilagođavali sebi. Intrigirajuće je kako različiti argumenti glede poimanja dobrobiti djeteta mogu trasirati potencijalne puteve prema roditeljstvu na oprečan način. Putevi stvaranja obitelji tako izgledaju uobičajeniji, 'organskiji', a time i manje komercijalni, manje klinički, manje u interesu roditelja, a više u interesu djece.

Podaci do kojih je autor (v. supra) došao u svom istraživanju lezbijskih, homoseksualnih i biseksualnih osoba u Engleskoj i Walesu ukazuju na poseban način kako roditeljstvo može biti višeznačno (pa tako i po ovoj osnovi) predmet etičkih razmatranja. Naime, oni pokazuju da standard 'dobrobiti djeteta' može biti fleksibilno primijenjen za opravdanje različitih načina zasnivanja roditeljstva. To omogućava slobodu roditeljima da odaberu argumente koji opravdavaju njihove odluke za stvaranjem obitelji na jedan ili, pak, neki drugi način. Ali, to također znači da koji god smjer oni odabrali, osjećaj eksperimentiranja nad djecom ili, naprosto, nepoštenog odnosa prema djeci, vjerojatno ostaje. Kažemo, vjerojatno. ${ }^{142}$ Naime, s obzirom na okolnost da, kako smo vidjeli, 'prirodnost' i 'normalnost' ne moraju nužno uzajamno, niti egzistirati, a ni jačati, ista čak može pružiti mehanizme pomoći takvim osobama (tj. takvim roditeljima) da otklone eventualne, moguće trajnije, ali $\mathrm{i}$ isto tako i epizodalne kritike vlastitih odluka o roditeljstvu.

Dakle, u ovakvom svijetu, u svijetu u kojem postoji kulturno-vrijednosni rat, u kojem 'prirodnost' i 'normalnost' nisu nužno osuđene na koegzistenciju, vidimo da su htijenja i interesi odraslih definitivno nadrasli dobrobit i interese djeteta.

140 Robert Pralat, „More Natural Does Not Equal More Normal: Lesbian, Gay and Bisexual People's Views about Different Pathways to Parenthood“, Journal of Family Issues, Vol. 39 (18), 2018., str. 4179, 4200 .

141 Više u: Shelley Day Sclater, Fatemeh Ebtehaj, Emily Jackson and Martin Richards (eds.), Regulating Autonomy - Sex, Reproduction and Family, Hart Publishing, Oxford and Portland, Oregon, 2009.

142 Robert Pralat, op. cit., str. 4201. 


\section{REPUBLIKA HRVATSKA - JEDNA U NIZU ŽRTAVA GLOBALNOG PLANA SEKSUALIZACIJE DJECE}

Ustav RH ${ }^{143}$ jasno propisuje: "Država štiti ... djecu i mladež, te stvara socijalne, kulturne, odgojne, materijalne i druge uvjete kojima se promiče ostvarivanje prava na dostojan život" (čl. 63.) i dalje: "Dužnost je svih da štite djecu" (čl. 65.).

Netom prije obrazovnog projekta pod nazivom "Škola za život” sadašnje ministrice B. Divjak, koji je predmet brojnih rasprava, dio obrazovne stvarnosti pripadao je zdravstvenom (spolnom) odgoju njezina prethodnika ministra Z. Jovanovića. U literaturi u kojoj se promiču sadržaji od pornografije do pedofilije, koja je, ne zaboravimo, bila namijenjena djeci osnovnih i srednjih škola, ne razaznaje se ni natruha "zaštite djece, kao ni kulturnog, odgojnog, socijalnog uzdizanja djece", o čemu progovara Ustav. Razaznaje se tek dosluh s diktatima međunarodne zajednice. Ni gender-ideologija ${ }^{144}$ ne bi se tek tako zatekla i na našem tlu, u našim "odgojima" kada njeni ključni promotori ne bi bile političke elite na vlasti. ${ }^{145}$ Shvatilo se da se kurikulumom famoznog 4. modula zdravstvenog odgoja ("Spolna/rodna ravnopravnost i spolno odgovorno ponašanje") može djeci vrlo lijepo približiti i rodnu ideologiju u osnovi koje strpljivo 'čuči' homoseksualnost kao pandan heteroseksualnosti. Naravno, da bi se to zakorijenilo u dječjim glavicama, (po)učitelj je morao pripaziti i na narativ. Isti bi, očekivano, morao obilovati empatijom, inkluzivnošću za sve i svakoga, razumijevanjem za drugačije, neprikosnovenom filantropijom. Ostaje za vjerovati da se u ovakvim 'odgojima' vodilo računa i o ispravnom probiru prezentera.

I sada, u eri “škole za život”, u doba erotizacije najmlađih, u doba koje je široko prigrlila domaća politička oligarhija koja diktate međunarodne zajednice želi odraditi 'kako treba', ne razaznajemo svjetlije budućnosti. Pomele su se tek neke sintagme, pojmovi koji su jasno progovarali o sadržajima namijenjenima našim

143 Ustav Republike Hrvatske (pročišćeni tekst), Narodne novine, br. 56/1990., 135/1997., 8/1998., 113/2000., 124/2000., 28/2001., 41/2001., 55/2001., 76/2010., 85/2010., 5/2014.

144 Zapravo, rodna teorija prerasta u rodnu ideologiju onda kada se zaniječe da je spol prirodna konstanta i ontološka datost te se spol razdvaja od roda. Upravo to sadrži Istanbulska konvencija. Kongregacija za katolički odgoj 10. lipnja 2019. objavila je dokument “'Muško i žensko stvori ih' - Za put dijaloga o pitanju roda u odgoju". Tom je prigodom kardinal G. Versaldi, inače pročelnik nevedene Kongregacije, istaknuo: "Rodne teorije, posebno one najradikalnije, udaljavaju se od naravne datosti kako bi posve stale iza odluke emotivnog subjekta. Tako spolni identitet, a time i obitelj, postaju 'fluidnima', zasnovani na trenutačnoj želji umjesto na naravnoj datosti i na istini o biću. Želi se izbrisati spolna različitost te je učiniti nevažnom za razvoj osobe”, Glas Koncila, br. 24, 16. lipnja 2019., str. 7.

145 Prisjetimo se samo famozne Interpretativne izjave koja je trebala donekle utišati hrvatsku javnost glede ratifikacije Istanbulske konvencije i njene poruke da se ni u kojem slučaju ne radi o uvođenju rodne ideologije u pravni i obrazovni sustav Hrvatske. Međutim, nije trebalo dugo da se pokaže punina vjerodostojnosti Intrerpretativne izjave. Naime, nakon nekoliko dana Ministarstvo znanosti i obrazovanja RH pripremilo je upitnik namijenjen mladim znanstvenicima, a odnosio se na "(Samo)procjenu stavova o mobilnosti" (boravku u znanstvenoj organizaciji izvan matične države, a u svrhu provedbe znanstvenog istraživanja). Upitnik je bio anoniman i sadržavao je nekih dvadesetak pitanja, međutim, dva su svakako zanimljiva: 1. Koliko imate godina? i 2. Označite svoj rod kao: muški (male), ženski (female) i preferiram ne odgovoriti (I prefer not to say). Vidi: https://narod.hr/hrvatska/dana-nakon-ratifikacije-ik-ministarstvoznanosti-i-obrazovanja-umjesto-spola-uvelo-rod, (preuzeto 30. X. 2019.). 
školarcima. Naime, spolni odgoj, ma kako da ga želimo upakirati ili preimenovati, a prije nekoliko je godina uveden u sve hrvatske škole, dio je kurikula.

Nacionalna politika za ravnopravnost spolova (2011. - 2015.) obvezala je RH: na uključivanje rodne dimenzije u sva područja politike provođenja posebnih mjera vezanih uz promicanje rodne ravnopravnosti ... pa tako i unapređenje primjene "rodno osjetljivog odgoja i obrazovanja". ${ }^{146}$ Potom, Hrvatska je 2018. ratificirala Istanbulsku konvenciju i pokazala sebi i svijetu kojim putem ide. Recentna praksa donošenja kurikula za razne "međupredmetne teme" (npr. Zdravlje, ${ }^{147}$ zatim Građanski odgoj i obrazovanje, ${ }^{148}$ Osobni i socijalni razvoj, ${ }^{149}$ Održivi razvoj ${ }^{150}$ i sl. /za osnovne i srednje škole/) pruža mogućnost da ono što se u famoznom 4. modulu zdravstvenog odgoja ("Spolna/rodna ravnopravnost i spolno odgovorno ponašanje") nazvalo punim imenom i naišlo, opravdano, na osudu javnosti, sada je uklonjeno, ali je svoj puteljak iznašlo u tzv. "međupredmetnim temama" koje sasvim dobro mogu podnijeti sadržaje koji su se nalazili u razvikanom 4. modulu. Tako se npr. u Kurikulu za međupredmetnu temu Građanski odgoj i obrazovanje navodi: “... prihvaćajući različitost kao značajku identiteta svakog pojedinca, učenici razvijaju osjetljivost za druge i za drugačije i prevladavaju stereotipe i predrasude". Ili, u Kurikulu za međupredmetnu temu Osobni i socijalni razvoj navodi se: “... važnost empatije te poticanja i prihvaćanja različitosti", kao i to da "različitost identiteta pridonosi bogatstvu zajednice". Znakovit je, na svoj način, i kurikul za međupredmetnu temu Održivi razvoj, u kojem se ukazuje na "nužnost solidarnosti i empatičnosti prema ljudima, identificira osnovne primjere dobrog odnosa prema ljudima". Pri tome nije loše pripomenuti već navedeno u jednom od prethodnih radova, ${ }^{151}$ da su Ujedinjeni narodi prihvatili Program održivog razvoja do 2030. ${ }^{152}$ i sedamnaest postavljenih ciljeva trajnog razvoja. Već u Preambuli Programa naglašava se "težnja za ostvarenjem ljudskih prava za sve i postizanje 'rodne jednakosti'”, a ista dobiva i posebno mjesto u okviru sedamnaest postavljenih ciljeva (konkretno, riječ je o cilju br. 5). Dakle, osim što se jasno daje do znanja da "nitko neće biti zanemaren", opetovano se ističe rodna nejednakost koja ostaje "ključni izazov" (toč. 14. Programa). Ostvarenju rodne jednakosti pridaje se "presudni značaj i važnost za ostvarenje i ostalih ciljeva Programa" (toč. 20.), a s takvim intencijama

146 Narodne novine, br. 88/2011.

147 Odluka (Ministarstva znanosti i obrazovanja) o donošenju kurikuluma za međupredmetnu temu Zdravlje za osnovne škole i srednje škole u Republici Hrvatskoj, Narodne novine, br. 10/2019.

148 Odluka (Ministarstva znanosti i obrazovanja) o donošenju kurikuluma za međupredmetnu temu Građanski odgoj i obrazovanje za osnovne škole i srednje škole u Republici Hrvatskoj, Narodne novine, br. 10/2019.

149 Odluka (Ministarstva znanosti i obrazovanja) o donošenju kurikuluma za međupredmetnu temu Osobni i socijalni razvoj za osnovne i srednje škole u Republici Hrvatskoj, Narodne novine, br. 7/2019.

150 Odluka (Ministarstva znanosti i obrazovanja) o donošenju kurikuluma za međupredmetnu temu Održivi razvoj za osnovne i srednje škole u Republici Hrvatskoj, Narodne novine, br. 7/2019.

151 Dijana Jakovac-Lozić, ,,'Rod' protiv 'spola' - polazište na putu razaranja braka i obitelji“, Zbornik radova Pravnog fakulteta u Mostaru, Petnaesto međunarodno savjetovanje Aktualnosti građanskog $i$ trgovačkog zakonodavstva i pravne prakse, 2017., str. 141.

152 Transforming our world: the 2030 Agenda for Sustainable Development, United Nations, 2015. 
teži se konačnom postignuću "društvu usredotočenom na ljude, rodno-osjetljivom, društvu koje poštuje ljudska prava ..." (toč. 74.e). ${ }^{153}$

Sve do sada izrečeno o kurikulima za pojedine međupredmetne teme zvuči, barem na prvu, sasvim benigno, općeprihvatljivo, ali, zapravo, isti mogu otrpjeti sve sadržaje koje bi otrpio i 4. modul. Moramo biti svjesni pozadine ovakvih nastojanja i ne smetnuti cilj kurikula 4. modula, događanja na međunarodnoj i domaćoj političkoj sceni nakon toga, te intencije međunarodne zajednice kojoj je Hrvatska poklonila svoje povjerenje. Naime, u svemu se da razaznati, između ostaloga, i neskretanje sa staze Smjernica UN-a namijenjenih djeci i mladima, o kojima je bilo riječi ranije (v. supra, 2.1.). Tužno je prepoznati s kakvom lakoćom 'odnarođeni' dočekuju i prihvaćaju puštene probne balone i šarlatanstva iz uvoza. Možda bi se to moglo popratiti tek sjetom kada bismo znali da nije namijenjeno najmlađima.

O brojnim razlozima u prilog nemjerljive štetnosti kojom generira seksualizacija djece i mladih govori i ugledna njemačka sociologinja G. Kuby koja je objavila više zapaženih radova o suvremenim društvenim kretanjima i kulturološkim fenomenima. ${ }^{154}$ Seksualizacija djece je, u svakom slučaju, atak na djetinjstvo, na djetinju nevinost $i$ djetinji sram koji ga obilježavaju. Američki pisac N. Postman ${ }^{155}$ kazao je da "bez razvijenog osjećaja srama, djetinjstva ne može biti".

Djetinjstvo mora biti prožeto osjećajem obiteljske/roditeljske ljubavi, zaštićenosti i sigurnosti. Ta slika ne trpi nikakve seksualne aluzije, asocijacije, poticanje djeteta na bilo kakve aktivnosti s takvom premisom, neovisno iz kojeg smjera bi dolazile (unutar ili izvan obitelji), na nasilan ili sofisticirani način (putem edukacije npr.). Svaki pokušaj i nastojanje na planu seksualizacije djece jest i atak na roditeljski autoritet koji se nalazi u zadnje vrijeme u tijesku društvenih diktata i zadanih 'suvremenih' edukacijskih programa. Država postaje ta koja nameće odgojne modele koji ne dopuštaju roditelju da odrađuje svoje roditeljsko poslanje sukladno vjekovnim prirodnim zadanostima. Standardi prirodnog tijeka hormonalnog razvoja (kod oba spola) i dobrobit djeteta u nesuglasju su s hiperseksualiziranim okruženjem (koje im nameće nešto za što nemaju ni fizičku ni psihičku, a ni seksualnu zrelost). I to treba nazvati pravim imenom - to je zločin. Nikakvi eufemizmi ne mogu prikriti njegovo zločinačko poslanje. Da i ne spominjemo problem dezorijentiranosti i zbunjenosti i kod djece i kod roditelja guranjem ideologije roda u život obitelji, a čiji je cilj, postaje vremenom sve jasnije, uništiti je.

U svom djelu Nova ideologija seksualnosti G. Kuby ovakvo stanje naziva "neprijepornim kulturnim propadanjem kojemu smo svjedoci", ističući da, "u središtu ovoga procesa stoji ukidanje norma na području spolnosti" te upozorava

153 Transforming our world: the 2030 Agenda for Sustainable Development, United Nations, 2015., https://sustainabledevelopment.un.org/post2015/transformingourworld, (23. III. 2017.).

154 Posebno bismo istaknuli dvije knjige Gabriele Kuby, 1. The Global Sexual Revolution: Destruction of Freedom in the Name of Freedom, LifeSite/Angelico Press, Brooklyn, NY, 2015.; 2. Nova ideologija seksualnosti - Izazovi i opasnosti gender revolucije, Verbum, Split, 2010.

155 Neil Postman (1931. - 2003.) američki je pisac i književni kritičar. Napisao je dvadesetak knjiga, a poznatije su: The Disappearance of Childhood, Amusing Ourselves to Death, Conscientious Objections i dr. 
da "treba dobro promisliti koja je cijena činjenice da se spolnosti oduzima njezin istinski smisao: sjedinjenje muškarca i žene u ljubavi i rađanje potomstva. Cijena su: slom obitelji, pobačaj, rodna indoktrinacija mladog naraštaja, opustošen život tolikih mladih ljudi i djece, mediji kao 'odgojitelji' tj. ugrožavanje mladeži i djece od strane medija i nastave spolnog odgoja, AIDS, demografski preokret". ${ }^{156} \mathrm{U}$ tom smislu, poziva se i na djelo engleskog antropologa J. D. Unwina Sex and Culture koji je ustvrdio: "što je veće ograničavanje spolnosti, to je veća razina kulture; što je manje ograničavanje spolnosti, to je manja razina kulture". ${ }^{157}$ Zaista, svega toga smo, nažalost, svjedoci.

Rekosmo, Hrvatska sada ima "Školu za život”. Bazirana je na projektu Alana de Bottona ${ }^{158}$ koji u svojim knjigama raznorodne tematike suvremenog života naglašava važnost i ulogu filozofije u istome. De Botton je i utemeljitelj tzv. Škole za život (2016.). No, njegove ideje i zamisli ni u jednoj europskoj državi nisu postale dijelom kurikula, osim kod nas. Najblaže rečeno, začuđujuća je, na određeni način, i sama spoznaja o temeljima pristupa reformi obrazovanja u Hrvatskoj baziranoj na nečemu čije prednosti i potrebu za preuzimanjem u osnovu nacionalnog kurikula nitko nije 'prepoznao' osim nas. Uz upitnost evaluacije, spremno smo ušli u eksperimentiranje, za budućnost, najosjetljivijim i najranjivijim resursom. U pravilu, iza pretjerane hrabrosti, očekivano stoji i dobra doza, barem, nedovoljne odgovornosti. Po sistemu 'važno je da se nešto događa'.

Već na prvi pogled, a nastavno na ranije spominjanu "konfuziju autoriteta", i u Hrvatskoj, u eri reforme obrazovanja obilježene sintagmom "škola za život" gdje sadržaj u mnogome nije dostojan naziva, iskazuje se otvoreno, najblaže rečeno, 'nepovjerenje' prema roditeljima i to do te mjere da im se ograničava čak i mogućnost pravdanja izostanaka djece s nastave. Umjesto toga, traže se liječnička uvjerenja. Dakle, ne samo da je to atak na poslanje roditeljske uloge, prava i dužnosti, već ih se pokušava i pred vlastitom djecom prikazati potencijalnim lažljivcima kojima sustav ne može pokloniti povjerenje niti na razini potvrde za izostanak s nastave.

Ne treba posebno ni govoriti o ignoriranju uloge ne samo roditelja, nego i svih onih koji se istinski brinu o dobrobiti djece i zdušno se zalažu da dobiju odgovore na upite glede, primjerice, problematičnih popisa školskih lektira u hrvatskim osnovnim i srednjim školama, u kojemu su mjesto iznašle i knjige potpuno neprimjerenog sadržaja (iste vrve prostotama, perverzijama svih vrsta i boja, od prostitucije do pedofilije kao najnormalnijeg priklona u esenciji ljudske seksualnosti). Umjesto da takvi dobiju očekivane odgovore na postavljene upite, dobijaju eklektička prtljanja, rezultat kojih je neuspjeli pokušaj spajanja istovremeno nespojivog, a popabirčenog iz raznih područja (od filozofije do medicine i prava). U svakom slučaju, jasnog odgovora na upit zašto su neki naslovi uvršteni u školsku lektiru čija bi svrha trebala počivati na misaonom, duhovnom, kulturnom, intelektualnom uzrastanju, životno

156 Kuby, G.: Nova ideologija seksualnosti - Izazovi i opasnosti gender revolucije, Verbum, Split, 2010., str. 8-9, 33-34, 76-78, 110-112.

157 Op. cit., str. 9.

158 Inače, gore spomenti autor objavio je i nekoliko knjiga na temu 'škola za život', a posljednja je The School of Life: An Emotional Education, Penguin Random House, Hamish Hamilton, London, 2019. 
važnom opismenjavanju djece - nema. Nije teško pretpostaviti zašto ga nema. Nema ga jer bez trunke odgovornosti, radoholično prihvaćamo sve diktate europske, uopće međunarodne zajednice, ne osvrćući se na posljedice. Očigledno, za jedan manji dio hrvatskih građana, koji bi trebao ponajprije svojim ljudskim, moralnim, a onda i političkim, profesionalnim habitom biti istinski odbojnik spram upliva ovakvih i sličnih pojavnosti u hrvatskoj stvarnosti ali koji, istovremeno, živi u nekom svom upamučenom mjehuriću, kao da postoji samo "danas".

U eri posvemašnjeg prihvaćanja Istanbulske konvencije, koja je krajem 2018. godine stupila na snagu i u Republici Hrvatskoj, ${ }^{159}$ "rodno neutralni ${ }^{160}$ odgoj i obrazovanje" postaju dijelom naše stvarnosti. Ona, koja gandijevski "nudi nenasilje", sva je od nasilja satkana. Kroz javne je medije zagovornici njenih ideja promoviraju, u prvom redu na način da se prema djeci u obiteljima, vrtićima, školama, domovima treba odnositi potpuno neovisno o njihovu spolu. Uvjeravaju javnost u to kako upravo odrasli nesvjesno stvaraju "rodne stereotipe" kod djece (učenjem određenom ponašanju, odabirom odjeće, ${ }^{161}$ igračaka, ${ }^{162}$ obraćanjem, oslovljavanjem i sl.). Inače, pojam "stereotip", kojim se zagovornici rodno neutralnog odgoja rado služe, a sve u svrhu poduke 'neprosvijećene javnosti', nema jasno određeno značenje u znanosti. Njegovo pojašnjenje, promatrano kroz dimenziju socijalnog razvoja (ranog djetinjstva, adolescencije i sl.), moguće, najčešće susrećemo u području socijalne psihologije. ${ }^{163}$ Kolokvijalno, ovaj pojam se nerijetko koristi upravo onda kada se pokušava ukazati na ujednačenost, nepromjenjivost, ukalupljenost, neoriginalnost. U jedno od poslanja rodne ideologije očigledno spada i igra na planu redizajniranja (najprije nominalnog, a onda i psihološkog i fizičkog) "malih ljudi", djece. Međutim, tome prethodi diskreditacija svega onoga što bi trebalo predstavljati otpor ideji, a za to se najzgodnijim čini pojam "stereotipa". Naravno, jasno je i tko je krivac, tko 'hrani' takve stereotipe. To su roditelji. Sve jasnija je, po procjeni rodnih ideologa, roditeljska nedoraslost ulozi koja im je od iskona pretpostavljena. Stoga, konačno bi je bilo 'poželjno prepustiti' - društvu, tj. dijelu 'osviještene' društvene zajednice.

Uz navedeno, Hrvatska je opremljena i propisima uz koje će njena djeca odrastati, pa i u tome 'borci za prosvjetljenje najmlađih' vide razložnost da se s djecom već

159 Hrvatska ju je ratificirala 12. lipnja 2018., a 1. listopada 2018. stupila je na snagu. Vidi: Zakon o potvrđivanju Konvencije Vijeća Europe o sprečavanju i borbi protiv nasilja nad ženama i nasilja u obitelji, (Narodne novine - Međunarodni ugovori, br. 3/18.).

160 Rodna neutralnost uvukla se i u tekstove državnih himni. Primjerice, iz nacionalnih himni Austrije, Kanade, a na tom putu su i Norveška i Njemačka, pojedini su izrazi zamijenjeni spolno neutralnim izrazima.

161 Primjerice, tvrtka John Lewis, a i mnoge druge, ukinula je oznake "dječaci” i "djevojčice” na dječjoj odjeći s kratkim obrazloženjem “We won't reinforce gender stereotypes”. Vidi: Louise Eccles, “John Lewis ditches 'boys' and 'girls' labels from its children's clothes to avoid reinforcing gender stereotypes”, Daily Mail, 1 September 2017. (preuzeto 4. XI. 2019.).

162 O stereotipima i dječjim igračkama čak se, u novije doba, raspravlja i u najvišim zakonodavnim tijelima pojedinih država. Primjerice, u francuskom Senatu (gornjem domu francuskog parlamenta) upravo su igračke i stereotipi bili tema rasprave. Senat je, potom, izdao niz preporuka proizvođačima igračaka, roditeljima, nastavnicima. Uvode se čak i oznake koje potvrđuju proizvođačevu osviještenost o rodnoj ravnopravnosti.

163 Donald C. Pennington, Kate Gillen, Pam Hill, Social Psychology, Routhledge, New York, 2016., str. 31-70. 
zarana postupa kao s odraslima. Primjerice, u Hrvatskoj je na snazi već nekoliko godina Zakon o životnom partnerstvu osoba istog spola, ${ }^{164}$ Zakon o suzbijanju diskriminacije. ${ }^{165}$ Hrvatska poznaje dvadeset i jednu osnovu diskriminacije, a među njima i diskriminaciju glede rodnog identiteta i izražavanja (rodnog identiteta) (čl. 1. st. 1.). Tu je i Zakon o ravnopravnosti spolova ${ }^{166}$ koji ne progovara samo o uklanjanju neravnopravnosti spolova, već i rodnih stereotipa (čl. 14.). Zakonom o državnim maticama ${ }^{167}$ kao i Zakonom o izmjenama i dopunama ZDM-a, ${ }^{168}$ Pravilnikom o načinu prikupljanja medicinske dokumentacije te utvrđivanju uvjeta i pretpostavki za promjenu spola ili o životu u drugom rodnom identitetu (dalje: Pravilnik) ${ }^{169}$ uređuju se prava transrodnih osoba u Hrvatskoj (iz čl. 4. st. 3. Pravilnika razvidno je da se kao podnositelj zahtjeva /osim roditelja ili skrbnika djeteta/ može pojaviti i samo dijete). Godine 2016. donesene su i Stručne smjernice za izradu mišljenja zdravstvenih radnika i psihologa o utvrđivanju uvjeta i pretpostavki za promjenu spola i životu u drugom rodnom identitetu. ${ }^{170}$ Iste, između ostalog, navode i: "Adolescenti/ce mogu biti prikladni za početak feminizirajuće/maskulinizirajuće hormonalne terapije, najbolje bi bilo uz roditeljski pristanak". Dakle, tek bi 'najbolje bilo' da je tome tako. Netom nakon toga slijedi: "U idealnom slučaju, odluke oko tretmana donose zajednički adolescent/ica, obitelj i liječnički tim". Dakle, pristanak roditelja bi bio uklopiv i tretiran kao 'idealan slučaj' ali, stara uzrečica: "Onog koga nema, bez njega se može”, kao da je i ovdje iznašla svoje mjesto jer je već jedno duže vrijeme nadišla okvir lokalnog, postavši dijelom globalnog, europskog poimanja važnosti i značaja roditelja i roditeljske uloge. Roditelji i njihovo mišljenje, kako smo već ranije imali prilike vidjeti, nisu neophodni u takvim, prema procjeni društvene zajednice, gorućim pitanjima za 'dobrobit' njihove djece.

I dok su neke države (npr. Njemačka i Češka) uporno odbijale donošenje "antidiskriminacijskih zakona" ističući da su antidiskriminacijske norme već ugrađene u njihove ustave i druge zakone, ukazujući na nepotrebnost umnožavanja propisa o nečemu što je već regulirano, ${ }^{171}$ Hrvatska je marljivo prionula poslu donošenja istih.

Imajući na umu djecu, slobodno možemo kazati da je ovakav pristup krajnje dijaboličan, patološki i zao pristup djetinjstvu i odrastanju. Djeci se od strane odraslih upravo nameće iščašen pristup vlastitoj spolnosti i spolnoj ulozi kao

164 Zakon o životnom partnerstvu osoba istog spola, Narodne novine br. 92/2014.

165 Zakon o suzbijanju diskriminacije, Narodne novine br. 85/2008. i Zakon o izmjenama i dopunama Zakona o suzbijanju diskriminacije, Narodne novine br. 112/2012.

166 Zakon o ravnopravnosti spolova, Narodne novine br. 82/2008, 138/2012.

167 Zakon o državnim maticama, Narodne novine br. 96/93.

168 Zakon o izmjenama i dopunama ZDM-a, Narodne novine br. 76/13., čl. 6. i čl. 9a. st. 2. Godine 2019. donesen je i Zakon o izmjenama ZDM-a, Narodne novine br. 98/2019.

169 Pravilnik o načinu prikupljanja medicinske dokumentacije te utvrđivanju uvjeta i pretpostavki za promjenu spola ili o životu u drugom rodnom identitetu, Narodne novine br. 132/14.

170 Stručne smjernice za izradu mišljenja zdravstvenih radnika i psihologa o utvrđivanju uvjeta i pretpostavki za promjenu spola i životu u drugom rodnom identitetu, Narodne novine br. 7/2016.

171 Češki predsjednik Vaclav Klaus "lupio vetom taj zakon, premda ga je parlament izglasao", Vidi: Šola, I., „Agora“, Slobodna Dalmacija, 23. IV. 2017., str. 10. 
suvremen, trendovski, oslobađajući i nesputavajući. Instrumenti za njegovu provedbu prepoznati su u mehanizmima odgojno-obrazovnih sustava i to od najranije životne dobi. Uči ih se, točnije, uvjerava ih se, da mogu biti i ono što nisu, ili kako to već promotori ideje kažu, "dajmo im slobodu da budu ono što jesu”, a pri tome je dovoljna tek puka želja kojih je, i inače, obilje u razdoblju života kad je dijete najosjetljivije, kad se traži, tako da promicateljima ideje put do cilja nije težak. Već su, skoro, i stigli do cilja ako znamo da, primjerice, u Americi, a i u mnogim državama Europe, roditelj za mnogo toga mora dati svoj pristanak kao djetetov zakonski zastupnik, ali isti se ne traži npr. i za promjenu spola. Ta snaga destrukcije, rušilaštva svega onoga što se ne uklapa u njen pakosni plan, udara na najosjetljivije, najranjivije ali i najvrednije - na obitelj, na brak, na djecu, na kondicionirane mehanizme i jamstva opstojnosti civilizacije. ${ }^{172}$

Hrvatska, kao dio međunarodne zajednice, postaje poput brojnih drugih država žrtvom globalne seksualizacije djece. Razne 'ekspoziture' međunarodnih organizacija, naprosto, rješenje brojnih svjetskih problema prepoznaju u stvaranju neke "nove vrste ljudi", a put do istih najvećim dijelom vodi upravo preko seksualizacije najmlađih. Tako se istovremeno ostvaruje dvojak cilj: 1. radi se otklon i bijeg od stvarnih problema s kojima se djeca današnjice suočavaju, ne pomaže im se, pače postojeću traumatizaciju liječi se dodatnom, točnije, 2. djeci kao najradoznalijim istraživačima nudi se rana seksualizacija s konačnim ciljem stvaranja unificirane, akceptabilne misli spram spolnih i rodnih ideja i ideologija suvremenog doba koje se stavljaju ispred samog čovjeka, te bezgranične mogućnosti i dopustivosti kombinatorike odnosa na planu ljudske spolnosti i seksualnosti. Usudili bismo se reći da djeca nikada u prošlosti nisu bila izložena tako orkestriranim nastojanjima glede mijenjanja vlastite im svijesti. To bi trebao biti i vrhunac manipulativnih eskapada odraslih nad djecom.

Roditelji su oduvijek bili prvi pozvani baviti se vlastitom djecom. Sada je njihova uloga, zaista, nezavidna. S jedne strane, zbog ozbiljnosti međunarodne zajednice koja im kroz odgoj i obrazovanje korištenjem bespogovornih metoda 'oduzima' vlastitu djecu, pri tome koristeći faktor zbunjenosti i nesnalaženja roditelja u njenom Blitzkrieg djelovanju. Naravno, nezavidnu poziciju roditelja, u konačnici, još težom čine nacionalni korifeji na koje međunarodna zajednica računa. Pri tome, međunarodna zajednica snažnu logistiku razaznaje u mehanizmima lingvističkog inženjeringa, oprezno i lukavo baratajući pojmovima za koje vjeruje da ih nije uputno koristi u njihovom originalnom značenju pa iste "utapa" u floskule s duboko promišljenim, edifikativnim, pedopsihologijskim, humanim predznakom.

U konačnici, i hrvatsku stvarnost, po ovom pitanju, možemo promatrati kroz leću zločinačkog kaleidoskopa u kojemu prepoznajemo i djecu i roditelje kao žrtve.

172 Više, u: D. Jakovac-Lozić, ,'Rod' protiv 'spola' - polazište na putu razaranja braka i obitelji“", Zbornik radova Pravnog fakulteta u Mostaru, Petnaesto međunarodno savjetovanje Aktualnosti građanskog i trgovačkog zakonodavstva i pravne prakse, 2017., str. 142. 


\section{UMJESTO ZAKLJUČKA}

Činjenica je, živimo u vremenu bujanja seksualnih prava, ali istovremeno i gašenja ili barem erodiranja dječjih prava, radničkih prava, prava nerođenih, starijih, bolesnih... Osim što je to uvreda za zdrav razum, istovremeno je i put u zemlju 'nedođiju'.

Profesor psihijatrije, neurologije i psihoterapije dr. Raphael Bonelli sa sveučilišta S. Freud u Beču u jednom je intrevjuu ${ }^{173}$ na upit zašto poduka iz spolnog odgoja počinje tako rano, već u prvim razredima osnovne škole, i tko od toga ima koristi, kazao: "Ako spolni odgoj već tako neprimjereno rano započinje, tada iza toga stoji najčešće neka izopačena filozofija. Stalno se susrećemo s pacijentima koji su vrlo često kao djeca u osamdesetim godinama prošlog stoljeća morala živjeti u komunama sa slobodnom i intenzivnom seksualnošću, a sve to je počivalo na neispravnoj zamisli da se djecu mora osloboditi od njihova straha i srama jer bi inače bila neurotična. U seksualizaciji djece razaznavalo se rješenje unutarnjih napetosti, a za samu djecu to je predstavljalo ništa drugo do li strašnu patnju. Koliko god to danas zvuči neobično, tada su posve ozbiljno tako razmišljali. Tako je iz lijevo-alternativnih krugova došao i zahtjev za legalizacijom pedofilije”. I u nekim drugim istupima prof. Bonelli ističe da 'liberalna pedagogija', psihološki gledano, počiva na metodama kojima se služe pedofili: djecu se zbunjuje mnoštvom prijevremenih i neprikladnih informacija o seksualnosti, zbog čega ona postaju žrtve tih trauma i razvijaju nezdrav odnos prema seksualnosti. Postaju potencijalne žrtve samih pedofila ili i sami postaju počinitelji kaznenih djela iz pedofilskog spektra. Na upit kako se djecu može u hiperseksualiziranom svijetu zaštititi, ali istovremeno i pripremiti za izvanjski svijet, kazao je kako tu treba balansirati jer se radi o vrlo složenoj situaciji. Naime, tu je s jedne strane prisutan prirodan interes djeteta koji započinje s ranim pubertetom, a s druge strane tu je surova stvarnost svijeta odraslih i njihovih planova s djecom, koje oni najpotpunije ostvaruju kroz obrazovne programe neprimjerene dobi i zrelosti djece. ${ }^{174}$

Jasno je, spomenuta liberalna pedagogija i pripadajući joj 'odgoji' potiču i provociraju zbunjenost kod djece glede njihova spolnog identiteta, što je višestruko bitno (s biološkog, psihološkog, društvenog aspekta). Tijek prolaska kroz pojedine faze odrastanja podrazumijeva i propitivanja vlastitih osjećaja i spolnog identiteta. U nekoj od njih, ne mogavši spoznati prolaznost iste, djeca mogu upravo pogrešno prepoznati sebe kao osobu s homoseksualnim aspiracijama, a samim tim i kao homoseksualca. Nadalje, ovakvi 'odgoji' kod djece stvaraju zbunjenost i po pitanju strukture i poslanja same obitelji. Dijete se udaljava od istinskog temelja obitelji, od istine da su muškarac i žena počelo iste, dakle dvije osobe različitog spola. Ono počinje shvaćati i doživljavati obitelj tek kao svojevrsni društveni odnos u kojem je 'osjećaj' sintetička kap koja može spojiti bilo koje, bilo kakve ljude, neovisno o spolu.

173 Stephan Baier: Die Tagespost: Prof. Dr. Raphael Bonelli über frühe und übergreifende Aufklärung in den Schulen, 11. IV. 2017., http://www.sexualerziehung.at/raphael-bonelli-psychiater-ueber-frueheund-uebergreifende-aufklaerung-in-den-schulen (preuzeto 29. X. 2019.).

174 Ibidem. 
Sva tragika ovakvih nastojanja razaznaje se u potrebi uklopivosti djece u svijet kojem ovo društvo teži. Njemu su potrebni prilagođeni, jednoobrazno odgojeni poslušnici. Totalitarizam ne trpi potencijalne oponente. U tom začaranom krugu dijete postaje igračka u rukama odraslih. Upravo ono koje više od ičega treba djetinjstvo koje mu nitko ne bi smio krasti, ni na koji način. A još je strašnije kada se to radi pod geslom njegove dobrobiti.

Prateći informacije u medijima, ${ }^{175}$ suočavamo se sa sveprisutnom histerijom i frenetičnim aplaudiranjem svim novotarijama na tom planu, što svakom iole razumnom biću postaje zastrašujuće.

175 Nailazimo na naslove kao što su: Najniža dobna granica u svijetu za transrodna prava, vidi: How young is too young? The optimal age for transitioning for transgender and gender nonconforming youth, Clinical Endocrinology News, June 23, 2016, https://www.mdedge.com/endocrinology/articel/109858/mental-health/ how-young-too-young-optimal-age-transitioning-trensgender (preuzeto 3. XII. 2019.).

Zlatni standard - nepostojanje službene dobne granice za promjenu spola kod djece. U kanadskoj je pokrajini Ontario nedavno (2017.) usvojen Zakon kojim se relativizira značaj uloge roditelja u odgoju djeteta (isti predviđa oštre sankcije za one roditelje koji nisu otvoreni spram odgojnih i obrazovanih metoda koje zagovaraju homoseksualnost, rodnu ideologiju i sl. Mogu biti kažnjeni i oduzimanjem djeteta jer, ako na bilo koji način suprimiraju ili onemogućavaju dijete da slobodno izražava svoju seksualnost, svoja opredjeljenja i sklonosti, nisu pokazali spremnost za poštovanje "najboljeg interesa djeteta"/v. supra, 2.2./);

Nižu se i dalje naslovi koji bude pozornost, kao:

U Njemačkoj, od 2013. godine roditelji imaju mogućnost ostaviti praznom rubriku u kojoj se navodi spol njihova djeteta. Vidi: Melissa Eddy and Jessica Bennett, „Germany Must Allow Third Gender Category, Court Rules“, The New York Times, November 8, 2017, https://www.nytimes.com/2017/11/08/world/europe/germanythird-gender-category-vanja.html (preuzeto 11. II. 2018.).

Spolni odgoj u Austriji sada podrazumijeva i tzv. kreativne radionice za izradu spolnih organa. Naime, od djece se zahtijeva da oni sami izrade spolne organe po uzoru na vlastite. Navodno, svrha je takve vježbe promicati kod djece potrebu da cijene svoje vlastite spolne organe, a tako i svoj vlastiti spol. Rekli bismo, još jedna od laži nalijepljenih na čelo projekta sustavne seksualizacije najmlađih. Vidi: Spolni odgoj u Austriji: Kreativne radionice za izradu spolnih organa, http://zdravstveniodgoj.com/news/spolni-odgoj-u-austrijikreativne-radionice-za-izradu-spolnih-organa (preuzeto 16. I. 2018.).

Djeca predškolske dobi u Svedskoj sudjelovala u gay paradi (Kindergarden kids in Sweden attending gay pride parade, https://www. youtube.com/watch? $\mathrm{v}=\mathrm{yruMjGhqRuw \& feature=emb \_ logo}$ (preuzeto 3. XII. 2019.). Transrodna osoba u Finskoj rodila dijete (Finland's First Openly Transgender Man Gives Birth), Culture trip, https://theculturetrip.com/europe/finland/articles/finlands-first-openly-transgender-man-gives-birth/ (preuzeto 3. XII. 2019.)

Nacrt talijanskog zakona 'Scalfarotto' predviđa uvođenje zločina homofobije i rodne idelogije u talijansko društvo (za spomenuti je da isti, istovremeno, priječi roditeljima učenika uključenost u izradu nastavnih planova i programa), ( The Scalfarotto Law and LGBT Rights in Italy), One Europe, http://one-europe-net/lgbt-rightsitaly (preuzeto 3. XII. 2019.).

Norveška donosi zakon o promjeni spola za sedmogodišnjake, dakle, to će vrijediti i za djecu od sedam godina i to bez prethodnog stručnog mišljenja liječnika ili psihologa (?!). Ponosni su na to jer više neće o tome odlučivati medicinska struka, već sama osoba, kako je svojedobno istaknuo i ministar zdravstva Bent Høie (Norway to let 7-yr-olds change gender), https://www.thelocal.no/20150625/norway-to-let-7-yr-old-changegender (preuzeto 3. XII. 2019.).

Belgija je 6. država koja je omogućila promjenu spola rodnim samoodređenjem (New legal gender recognition legislation approved by Belgium), https://www.ilga-europe.org/resources/news/latest-news/newlegal-gender-recognition-belgium (preuzeto 3. XII. 2019.).

U prestižnoj britanskoj ženskoj školi /James Allen's Girls' School/ zabranjeno je učenice nazivati djevojčicama jer bi to mogla biti uvreda trans-učenika (takav grijeh, točnije, verbalni delikt jednog je britanskog učitelja stajao čak i radnog mjesta. Naime, prigodom objave rezultata ispita iz matematike, rekavši: "Odličan posao, djevojke!", nije znao da jedna od njih ne želi da je se tako oslovljava jer se ista identificira kao dječak. Skola je njegov istup ocijenila diskriminatornim). Vidi: Lara Keay, My girls are not 'girls': Head of the top single-sex school says she only uses 'pupils' to describe youngsters so not to hurt feelings of any considering changing sex, MailOnline, 24 September 2017, https://www.dailymail.co.uk/news/article-4914372/HeadLondon-girls-school-does-not-call-pupils-girls.html (preuzeto 12. II. 2018.)

Irska omogućava djeci koja su navršila 16 godina promjenu spola u dokumentima na temelju rodnog samoodređenja. Vidi: Ireland passes law allowing trans people to choose their legal gender, https://www. theguardian.com/world/2015/july/16/ireland-transgender-law-gender-recognition-bill-passed (preuzeto 12 . II. 2018.). 
Opasnom se čini ta 'ideologija oslobađanja', ideologija koja oslobađa sve one koji se nađu zatočeni u okovima stereotipa, a k tome, vrlo su okrutni i njeni penalisti. To, dodatno, možemo popratiti i kroz iskustvo njemačke učenice koja nije htjela nazočiti dvosatnom predavanju iz područja rodne ideologije. Njezinu je ocu zbog toga izrečena zatvorska kazna. ${ }^{176}$

Koliko je takvo obrazovanje štetno za djecu, s pravom ukazuje i psihijatar Rick Fitzgibbons, tvrdeći da je širenje rodne ideologije u obrazovnom sustavu uzrokovalo porast dijagnoza poremećaja u rodnom identitetu među djecom i mladima. Primjerice, u Ujedinjenom Kraljevstvu broj djece koja se podvrgavaju takvim tretmanima u posljednjih nekoliko godina se učetverostručio. Djeca koja čak i izražavaju transrodna osjećanja, ali ista ne budu popraćena medicinskim ili kirurškim tretmanom, prema iskustvima Vanderbilt Sveučilišta (Nashville) i londonske Portman klinike, u 70 do 80 posto slučajeva spontano izgube takva i slična osjećanja. ${ }^{177}$ R. Fitzgibbons, prateći od 2011. godine populaciju koja je posegnula za kirurškim tretmanom promjene spola, zaključio je da je kod njih znatno povećan rizik smrtnosti, suicidalnog ponašanja i psihičkih bolesti. ${ }^{178}$

Trend preodgoja djece, kroz uvođenje nastave spolnog odgoja u škole, a pod parolom zaštite djece, rezultira ishodima 'poduke' koji su oprečni onima temeljem kojih su se takvi odgoji uvukli u učionice diljem Europe i svijeta.

Primjerice, upoznavanje djece s kontracepcijom ne smanjuje broj maloljetničkih trudnoća, pače, povećava ih, pa je tako u Engleskoj broj pobačaja kod djevojaka mlađih od šesnaest godina u četrdeset godina porastao tri puta. Bez obzira na neuspjehe i sve ranije stupanje u spolne odnose, inzistira se na spolnom odgoju te traži još veća eksplicitnost i sve ranije podučavanje čak i kod predškolske dobi. Godine 1995. Europska je unija odobrila projekt European Network of Health Promoting School (ENHPS), po kojem spolni odgoj treba započeti već s tri godine (!?). U Njemačkoj, koja je već sedamdesetih godina prošlog stoljeća uvela spolni odgoj u škole, statistike pokazuju kako je u razdoblju od samo pet godina (1996. 2001.) broj pobačaja kod djevojaka ispod 18 godina porastao za cijelih 35 posto, a u samo tri godine prosječna dob stupanja u spolne odnose spustila se sa 15,6 (rođeni 1977.) na 13,7 (rođeni 1980.). Ipak u toj istoj Njemačkoj, Ministarstvo obitelji uz pomoć Savezne središnjice za zdravstveno obrazovanje (BzgA), ustrajno radi na što ranijoj seksualizaciji djece, već od prve godine života i na školskom osposobljavanju djece od devet godina za korištenje kontracepcije. Homoseksualnost, skupa s biseksualnosti i transseksualnosti, službeno se pak podučava u školama od desete godine života i to ne samo putem spolnog odgoja nego i kroz druge predmete.

176 Roditelji su kazali da se djecu u Njemačkoj počinje ‘cijepiti’ rodnom ideologijom već u vrtiću. U školi je seksualni odgoj, inače, obvezni predmet. Više: Unreasonable expectations: why the family of Eugen Martens returned to Germany, https://capelino.com/ureasonable-expectations-why-the-family-ofEugen-Martens-returned-to-Germany (preuzeto 1. II. 2018.).

177 Thaddeus Baklinski, Children as young as 3 referred to NHS for transgender treatments, https://www.lifesitenews.com/news/children-as-young-as-3-referred-to-nhs-for-transgender-treatments (preuzeto 3. XII. 2019.).

178 Ibidem. 
A u svemu se, kako konstantira G. Kuby, provlači "insinuacija ekvivalencije svakog oblika seksualne prakse - homoseksualne, transseksualne, biseksualne - s heteroseksualnošću." 179

Zapadnom kulturom, očigledno, upravlja tzv. konsenzualna etika koja je radikalno ambivalentna i bez stabilnog sadržaja. Razgradila je savjest, što ima za posljedicu da većina ljudi više ne razlikuje dobro i zlo. Napala je samu strukturu ljudske osobe pa je samim tim izazvala i antropološku kataklizmu. Njena se 'postignuća' ogledaju u prelasku s obitelji na parove i pojedince, sa supružnika na partnere, s braka na slobodnu ljubav itd. ${ }^{180}$ Uz nevjerojatnu pomoć lingvističkog inženjeringa, o kojem je lijepo progovorio G. Orwell u svom djelu "1984.", ${ }^{181}$ prešlo se na socijalni inženjering.

Ono što je zamjetno jest brzina navikavanja na novokomponirane uzdanice postmoderne. Navikavamo se na to da je rod, na određeni način, supstitut za spol. Dojučerašnji pojam spolne ravnopravnosti zamjenjuje pojam rodne jednakosti. Međutim, sadržaj je potpuno različit. Spolna ravnopravnost podrazumijeva komplementarnost, međusobno nadopunjavanje žene i muškarca, uz poštovanje dostojanstva koje proizlazi iz njihovih različitosti (ne samo fizičkih, tjelesnih), dok rodna jednakost anulira sve razlike i ima za cilj da postanemo tek ljudi s različitim seksualnim opredjeljenjima, orijentacijama, što s vremenom u kojem jesmo briše i potrebu za posebnim evidentiranjem kategorije spola u državnim maticama, registrima i sl. Ovako nešto protivno je elementarnim znanstvenim činjenicama (biologije, genetike, psihologije).

Biološke činjenice ne smiju se zaboravljati u žaru stvaranja novih društvenih agendi. Ovo je vrijeme kada ljudi preispituju postojanje znanstvenih dokaza o nuspojavama i eventualnoj štetnosti antibiotika koji piju, ali istovremeno pristaju na radikalne zahvate nad vlastitom djecom (uz pretpostavku da se od istih više uopće traži pristanak i za hormonalnu terapiju i za operativne zahvate nad vlastitom djecom). ${ }^{182}$

Navikavamo se, s dozom letargije, a rekli bismo i nedovoljne zainteresiranosti, na ono što nam serviraju svjetski centri moći, svi oni koji čak i javno govore da im je došlo vrijeme da iziđu iz sjene i otkriju svoje namjere, kao i međunarodna zajednica, nacionalna politika. Navikavamo se, htjeli to priznati ili ne, na to da rodna uravnilovka kreće već od vrtićke dobi pa nadalje, navikavamo se na sve škrabotine koje se stignu pretočiti u nacionalni propis, navikavamo se na sve što se servira nama i našoj djeci, unatoč iskustvima i svijesti da su brojni zakoni koji su proizlazili iz ideološki motiviranih utopijskih ideja imali upravo razorne posljedice. A ne treba

179 Josip Mužić, „Rat protiv čovjeka“, Glas Koncila, Zagreb, 2015., str. 25.

180 Više u: Marguerite A. Peeters, „Globalizacija zapadne kulturne revolucije - ključni pojmovi, mehanizmi djelovanja“, Glas Koncila, Zagreb, 2014

181 George Orwell, 1984. (With an Afterword by Erich Fromm), Signet Classics, Penguin Group, New York, 1977.

182 Lawrence Meyer, Paul McHugh, „Sexuality and Gender - Findings from the Biological, Psychological and Social Sciences“, The New Atlantis, A Journal of Technology \& Society, 2016., https:// www.thenewatlantis.com/publications/executive-summary-sexuality-and-gender (preuzeto 4. XI. 2019.). 
niti spominjati poslovičnu snagu i moć navike. Američki pisac Frank Crane kaže: "Navike su sigurnije nego pravila; ne morate ih nadgledati i ne morate ih čuvati. One čuvaju vas."

Jer ako postoji stereotipizirana kultura u kojoj je diskurs odvojen od stvarnosti, u kojoj ljudi više ne razmišljaju svojom glavom, onda je to upravo ona u kojoj živimo, postmodernost. $^{183}$

Bojazni glede neizvjesne nam budućnosti, poglavito naše djece koja zapravo i jesu naša budućnost, uz sve ostalo, dodatno pobuđuje i istup Belgijanca, inače europarlamentarca G. Verhofstadta (člana liberalno-demokratske stranke), koji je nedavno "pozdravio kraj vijeka nacionalnih država i početak novog svjetskog poretka u kojem Europsku uniju prepoznaje kao "imperij"". ${ }^{184}$ On novi svijet vidi kao 'svijet imperija', a ne 'svijet nacija-država'. Uz EU, takav prefiks dobile bi i Kina, Indija, SAD, Rusija (navodeći primjer Indije svoj stav argumentira na način da ondje postoji brojnost nacija, da se koristi 20 različitih jezika, da postoje 4 velike religije). Naravno, sve na štetu država, nacija. U takvom viđenju svijeta bliske nam budućnosti, obilježenog globalističkim pretenzijama, nažalost, nije usamljen. Takva budućnost imperija pogoduje svima onima koji su se i do sada zalagali za brisanje svih nacionalnih vrednota i posebnosti identiteta (kulturnih, povijesnih, vjerskih, etičkih), onima koji su zazivali hegemoniju a koja bi, koristeći raspoložive mehanizme globalizacije, podrazumijevala uskratu sloboda nacija uz neviđenu kontrolu nad čovjekom-pojedincem (kojoj iznimno pogoduju suvremene tehnologije, društvene mreže, internet i sl.), uz kontinuitet mrvljenja, usitnjavanja ljudskih prava do najsitnijih, s aspekta našeg interesa, najperverznijih prava u domeni ljudske spolnosti i seksualnosti (počevši od najranijeg djetinjstva), istovremeno ga čineći 'sretnim sužnjem', ali i osobom bez identiteta.

Ovakva ideologija suvremenog doba nadmašuje sve prethodne, pokazuje svu okrutnost čovjeka. Upravo je o okrutnosti, surovosti čovjeka najmjerodavnije progovorio F. M. Dostojevski, kazavši: "Zaista, ponekad se govori o zvjerskoj surovosti čovjeka, a to je strašno nepravedno i uvredljivo za zvijeri: zvijer nikada ne može biti tako svirepa kao čovjek, tako virtuozno, umjetnički svirepa. Tigar rastrga svoju žrtvu i to je sve. Tigar nikada ne bi pomislio žrtvu prikovati na križ”.

183 Jordan B. Peterson, 12 pravila za život - protuotrov kaosu, Verbum, Split, 2018., str. 172-173, 231, 323-324.

184 Anti-Brexit Lib Dems Cheer EU's Verhofstadt As He Hails 'World Order' Of 'Empires', https:// www.breitbart.com/europe/2019/09/15/anti-brexit-lib-dems-cheer-eus-verhofstadt-as-he-hails-worldorder-of-empires/ (preuzeto 20. I. 2020.). 


\section{ENDEAVOURS IN THE ,EARLY SEXUALISATION““ OF CHILDREN -INTEREST OF THE CHILD OR NEED OF THE ADULTS}

Among the important mechanisms in creating a new social order is indoctrination of children. In the era of prevalence of hegemonistic and globalist ideas and strivings, perceiving the future world as a mass with no history, culture and identity, at the time of ending, or at least eroding, the children's rights, the workers' rights, the rights of the unborn, the older, the sick, thrive sexual rights, in particular those targeted to the youngest. The endeavours towards an alienation from the reality aspire to the most disgusting - the sexualisation of the children. This is channelled firstly through the compulsory upbringing and educational models (from kindergartens to schools). Here, the role of the continuity of "widening the expance of the freedom" must not be forgotten as well, implemented through the influences created by the modern technologies (internet, social networks and like), these additionally widen the areas of possibilities of manipulation, and of controlling the influences to the children.

Behind this stand inclinations of the global centres of power, international organisations, from the United Nations, to the Council of Europe and the European Union. They are producing an exceptional "contribution" in the field of the above mentioned segment of the modern puericulture. At the same time, the parental role has never been at a greater test and has never been this much marginalised as it is now. The international community, proclaiming itself a fanatic "rectifier of the world", is depriving parents of their own progeny, educating and upbringing the later by the set postulates. However, besides the educational and upbringing programmes, the children are directly entered into the domain of early sexualisation, and through cohabitation with the "unnatural" parental (same-sex, transgender) environment, which is a part of the Croatian legal reality as well. We are wandering where in this entire commotion of hoarding and pulverisation of the human rights, importance of political and other correctnesses, there have been lost the benefit of the children as an imperative and the best interest of the child as a right above all other rights. They are lost just at the moment that we are to live - the moment of freedom of foolishness and shame of sane-mindedness.

Key words: child's rights, early sexualisation of children, United Nations, Council of Europe, European Union, health and sexual education of children 